This dissertation has been microfilmed exactly as received

$66-10,340$

EWTON, Jr., Ralph Waldo, 1938THE LITERARY THEORIES OF AUGUST WILHE LM SCHLEGEI.

Rice University, Ph.D., 1966

Language and Literature, modern

University Microfilms, Inc., Ann Arbor, Michigan 


\section{RIOE UNIVERSITY}

\section{THE IITERARY THEORIES OF AUGUST WIIHEIM SOHLFGEI}

Ralph weld byton, Jr.

A THESIS SUBMITTED

IN PARTIAI FUIFITIMEENT OF THE

REQUIREMIANTS POR THE DEGREF OF

DOOTOR OF PHIIOSORHY

Thesis Director's signature:

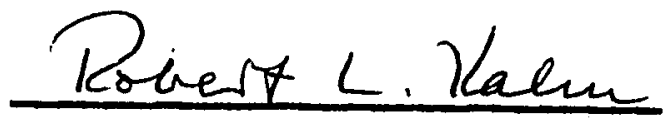

Houston, Texas

May 1966 
DONTENTS

Ohapter I: Introduotion

$$
\text { p.I }
$$

Ohapter II: The Speculative Hiatory of Poetic

$$
\text { Origins }
$$

$$
\text { p. } 24
$$

Ohapter III: Poesie, Genius and Phantasie

$$
\text { p. } 50
$$

Ohapter IV: The Poet1c Worla

$$
\text { p. } 68
$$

Ohapter V: Art and Nature

$$
\text { p.83 }
$$

Ohapter VI: The Audience's Fxperience of Poesie p.101

Ohapter VII: Iiterary Oriticism

$\mathrm{p} \cdot 108$

Ohapter VIII: Theory of Genres

p.120

Ohapter IX: Iiterary History

p. 138

Ohapter X: Olagsic and Romantio

$p \cdot 142$

Ohapter XI: Donolusion

$\mathrm{p} \cdot 156$

B1bllography

p. 173 
OHAPTER I

INTRODUOTION

The detalls of August W1Lhelm Schlegel's Ilfe and his accomplishments in other flelds than literary theory are the subjects of the mejority of scholerly works which deal With him. Our concern here 1s only to small extent with his activitieg as translator, medievalist and orientalist. Oloser to our subject 1s Schlegel the reviewer, historian and critic. The most recent discussion of Schlegel's literary theorles 1s by Rene Fellek. 1 Wellek considers the theories in their relevanoe to Schlegel's or1t1c1sm. The present study's emphas1s, however, is on the theories and deals oniy incldentally with his critiolsm. The subject has been relatively neglected by scholars of German Romentic1sm. The best account before that of Wellek was by Rudolf Haym in his Die Romantische Schule. ${ }^{2}$ Sohlegel's theories mer1t a more detalled exposition than either Wellek or Haym have given them. As an introduotion to this undertaking, a few words about Schlegel'g life, works and the men who influenced them w11l be helpful.

The most important early influenees on Schlegel were

${ }^{1}$ A Hitary of Modern Or1t101 sm, 1750-1950 (New Haven, 1955), II, 36-73.

23. Aufl., ed. Oskar Walzel (Berlin, 1914). 
Herder, of whom more w1ll be seid later, and two of his teachers during his student dxys at oftingen (17861791). Schlegel's firgt signifleant publication was his "De geographia Homerioa comentatio" (1788) written under the direction of the classical philologist Ohristian Gottlob Hejne (1729-1812). A more important mentorat Gottingen was, however, the poet Gottfrled August Blirger (1747-1794). He and Schlegel worked together in 1789 on a

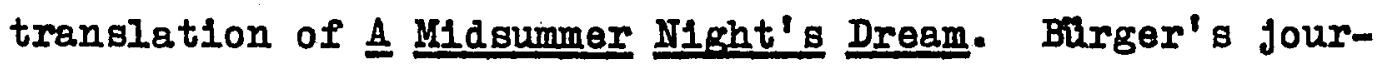
nal Akedemie der schönen Redekingte contalned Schlegel's earliegt poetry and an essay Mfor Dante und die gotttliche Komőd1e" (1791) together w1th a fow attompts at a Dante translation. The translation was added to unt11 1797 but remained a fragment.

In the jears 1789-91 Schlegel's first reviews appear In the Gottinger Gelehrten Anzelgen. These early replews were competent but reflect 11 ttle of the literary theoretiolan we meet later. The Dante essay, however, tries to oarry the reader back into Dante's world. Schlegel's deep sense of h1story and 1ts relevanoe to 11terature 1s characterlstic of his $11 \mathrm{fe}^{\prime}$ s work. His 1791 essay on Sch1ller's "Die Kinstler" should also be mentioned as a foretaste of what was to come. There a careful reading of Schiller's poem 18 preceded by a theoretical statement on the neture of didectic poetry. Poetic ingpiration 1s an apprehengion of truth. What the highest kind of didac- 
t1c poem teaches 1s, by this standard, poetio in nature and is not just a mere casting in verse of prosalc 1deas (SW, VII, 4-8). ${ }^{3}$ The Dante and Sohiller essays reflect two of the greatest influences on the direotion of Schlegel's thinking: the historical study of literature from Herder and Heyne and the philosophioal aesthetice of Sohiller and Kant.

At the completion of h1s university studies in 1791 Schlegel toor a position as private tutor in the house of an Amsterdam businessman. There he continued his literary attempts and began the Shakespeare translation. In the Amsterdam years Sohiller became Schlegel's poetic model and his correspondence with the poet led in 1794 to an invitation to write in Die Eoren. Schlegel's "Briefe uber Poesie, Sylbenma und Spreche" were published there in 1795 and 1796. A further theoret1cal endeavor of the same perlod was hls "Betrachtungen uber Metrik." Goethe also exerclsed a great influence on Schlegel, especially through W1lhelm Me1sters Lehrjahre wh1ch led in 1795 to renewed efforts on the Shakespeare translation and to two important essays, "Itwas Uber W1lliam Shakespeare bel Gelegenhe1t W1lheln Me1sters" in 1796 and the essay on Romeo and Jullet In 1797. The flrst af these lays down the principles of adequate translation of forelgn worics of literary art and 3 heferences in this form are to August Wilhelm Sohregef's

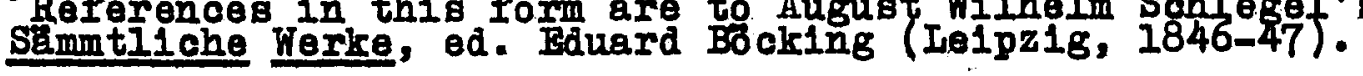


the siscond is a profound appreciation of Shakespeare as ar. artist. The bulk of the Schlegel translation of seventeen of Shakespeare's plays ras completed and pubIlshed in the years 1797-1801, with the addition of one small volume in 1810.

Schlegel had returned to Germany in 1795. In May of 1796 at Schiller's prompting he settled in Jene. This was the year of his marriage to Oaroline Bohmer and the beginning of an amazing production of reviews published in the Jenaische Allgemelne Ilteraturzeltung. In these we can see Schlegel's characteristic combination of historical and philosophical critlol sm and, in general, the practice of the critical theorles whlch will be our concern later in this study. As far as theoretical content is concerned, the most important of these essays is that of 1797 on Goethe's Hermann und Dorothea where, starting from Priedrich Sohlegel's thoughts on the subject, he works out his theorles of eplc poetry.

The reviews fust mentloned were at first Schlegel's Iivelihood. In 1798, however, his Shakespeare translations earmed him a professorship at the University of Jena. There he lectured on a number of subjects, among them aesthetics. The leptures on this subject were written down by a listener and are preserved in an edition by August Winsche: Vorlegungen uber phllosophlsohe 
Iunstlehre (Ielpzig, 1911).4 It should be mentioned here that these lectures deal with all the arts, not w1th Ilterature alone. Schlegel's thoughts on the plastio arts are only peripheral to this study. The subject was, however, of lifelong concerm to him. His desire to support the artistic claims of moderm alongside the classic in art was as great as his degire to do the same for 11terature. Architeoture, soulpture and painting oooupy whole sections of the Jena Iectures and of the first series of the Berlin Lectures. Numerous essays, dialogs, poems and fragments deal with these matters and they are the subject of another set of lectures delivered in Bonn in 1827.

The 1798 Iectures are of lesger significance than those of Berlin and Vienna. The reason is their almost complete concern with purely philosophlcal questions. Schlegel 1s at his best when he combines a historlcal and theoretioal approach to literature, an approach which he later justifies both in theory and in praotioe. History, Insofar as it 1s dealt with in the 1798 Iectures, is not really Iiterary history based on known works but rather 1s speculation on Urgeschichte, the supposed primordial orlgins of axt, and above all of Poogie. The tone of the lectures 1s rether pedant1c. Some of the1r abstractions are later supported by their application to ooncrete

${ }^{4}$ These lectures are o1ted in this study as 1798. 
Ilterary examples. Others, however, are forgatten or even contradicted by the more down to earth treatment of similar subjects in later lectures. The later lectures deal w1th art whereas the 1798 Lectures deal abstractly W1th the 1dea of art. Accordingly, the beginning chapters of this study will make the greatest use of the early lectures since there our conoern will be largely with a clarification of Schlegel's theoretical vooabulary. Schlegel's move to Jena brought him Into closer contact with Goethe and Schiller, but a strain on his relationship with the latter was soon brought about by Friedrich Schlegel's criticlom and the animosity between Schlller and daroline. Schlegel's turn away from the classical 1deals of Goethe and Schiller was later than that of his brother, but in the Jena period the change was gradually brought about by his nearness to Friedrloh and his contacts and friendships with Tleck, Novalis, Sohlelermacher and Schelling. Although Sohlegel from his earliest publications had shown great admiration for modern literature, it was not until his return to Germany that he and Frledrioh fully developed their 1deas of romantische Poesle and assoclated the products of the alrcle we now call the Older Romantio School with the early modern writers whom they themselves designated as romantic. The Journal of the new sohool was the Athengoum which the Sohlegels published Jolntly in Berlin from 1798 to 1800. 
Although the period of his collaboration on the fournal was important for Schlegel's developing romantic theorles, most of his contributions to the Athenaeum are only of peripheral interest here. Schlegel's satires and poems do not concern us and his fragments contain little about Ilterary theory. His theoretical statements which do appear there are for the most part concerned with the plastic arts.

In October of 1799 Schlegel broke off relations with the Aligemeine Ilteraturzeltung and in the summer of 1800 he gave his last lectures in Jena. Farly in 1801 he moved to Berlin where he continued hls translating and oriticlsm. In the same year he and Friedrich published their Oharakteristiken und Kritiken which contalned Wilhelm's essay on birger. In addition to the best of his previously pubIished oriticism. The most significant of his undertakings at this time was, however, the lectures on aesthetios and the history of classlc and romantic literature which were delivered in Berlin in three succeselve winters beginning in December of 1801.5 Sohlegel's audience was no longer an acedemic one. His lectures in Berlin were less pedantic than those in Jena, yet they embodied more philosophical insights than the earlier lectures. The influence

${ }^{5}$ Vorlesungen uber gchöne Ilteratur und Kunst, ed. Jakob Minor, Deutsohe Is teraturdenkmale des 18. und 19. Jahrhunderts, 17-19 (Stuttgart, 1884). These lectures are hereafter reforred to as Berilin. 
8.

of Fichte and Schelling is evident. The essential unity of critlcism, history and theory, maintained on theoretical grounds in the first series of Berlin Lectures, is proven in practice in the subsequent histories of olassic and romantic poetry. The view of ilterature presented here is largely that held in common with Friedrich Schlegel and the circle of the Schlegels' frlends. There are many personal insights, but the whole is an argument for the validity of views held by many. The excursions through literary history are, however, as original as any personal view of given historical facts can be.

Schlegel continued his translating, turning his efforts now to writers in the Romance languages. In 1804 he published his Blumensträupe 1 talienlsoher, spanischer und portugiestsoher Poesie. Tleck had aroused Schlegel's interest in Galderon and the two planned a joint translation. The joint project was abandoned, however, and Schlegel published his own translation of five plays by Calderon In 1803 and 1809 under the title Spanisches Theater. Other lesser efforts at tranglation were published in the fournal Europe (1803-1805).

Schlegel was divorced from daroline early in 1803 and 1t was later in the same year that, through Goethe, he met Mme. de Staell. His alliance with her soon led to wide travels, notably in France, Switzerland and Italy. H1s writings during the next f1ve years reflect continued 
efforts at poetry and drama, translation, criticism and theorizing on art and ilterature. Of particular interest to us is Sohlegel's concern with Frenoh dreme. Here his crlticlsm is almost completely negative, for he lacked all sympathy for rationalism and for neo-classicism and. Its corollary depreciation of the distinctively modern. This is reflected in his discussions of the French in the Vienna Iectures and in his famous essay "Comparaison entre la Phedre de Racine et celle d'Huripide" (written in French) published in 1807 .

Schlegel's travels with Mme. de Steël took him to Vienna in December of 1807. There, in the spring of 1808, he delivered. the most famous of his serles of lectures. They were soon published (1809-18II) under the t1tle Vorlesunger uber dramat1sohe Kunst und I1teratur. 6 These lectures were quickly translated into all the major Furopean languages and became the most widely read of all the works of German Romanticiam. Their popularity 1s chronlaled in Josef Körner's D1e Botschaft der deutschen Romant1k an Europa. 7

W1th few exceptlons, Schlegel's activities after the presentation of hls lectures in Vienna are of little concerm to us here. After the Vlenna Leotures theoretical

$\sigma_{\text {Hereafter clted as SW, V-VI. }}$ 7 (Augsburg, 1929) 
questiong are only in the beckground of Schlegel'g work. The bulk of his published writings between 1810 and his death in 1845 are historlcal and philologloal studies. The works which concern us most are, of course, the three serles of leotures delivered between 1798 and 1808 . To a lesser extent we are interested in those of Sohlegel's reviews which paraliel the lectures and in shorter treatments of theoretical matters. Nearly all the relevant statements come fron the years 1790-1810 and most from 1798-1808.

A survey of Schlegel's works reveals the following aocomplishments during his first two decades of writing: several volumes of poetry and drama, the Shakespeare translation, translations from the Romance languages and from Greek and Iatin, several hundred reviews which included some masterpleces of literary criticlsm, several minor theoretical works on poetry and the fine arts and, finelly, the three courses of lectures. A good many of his 11terary endeavors were in the mode of satire. This Is noteworthy here since the purpose of the above liat of Schlegel's undertakings is to point out the extent to which ho sought to influence publio opinion by his writing. In the jears named he wrote eplgrams, sat1res, parodies, reviews, critiolom, theoretical works, esseys and lectures all of which add up to some twelve volumes in the standard editions of Sohlegel's writings. 
It should be clear from what has just been said that Schlegel held points of view which he was concerned to Impress on the educated public. Some of his opinions are unique with him. Most of his oritical and theoretical writing was, however, concerned with a criticigm of neoclassicism while upholding the artistic cleims of the classic and the distinctively modern. It hardig needs pointing out that nelther philosophizing nor propagandizing along these lines was an aotivity carried on alone by August Wilhelm Schlegel. His tastes and antlpathies were shared by many of his contemporaries and most of his theoretical fustifications for his attitudes were also held in common with mentors and friends.

Schlegel's oriticism is characterized by thoughtful reading, the application of broad knowledge of literature and art and by personal insight. Many theoretical premises arise from his criticism and bear the mark of h1s individuality. Yet it is undeniable that in many respects his theories are eclectlc. He did draw from many sources. The question before us is that of his claim to be read.

Schlegel's success a a literary oritio 1s far more widely acknowledged than hls success as a literary theorist. But anyone who studies Schlegel's orlt1alsm must consider the theories at the same time. The best literary critics set down the basis of their judgments' claim to 
objective truth. Only within the framework of his theoriea does Schlegel's orltiolsm become more than an expression of purely personal likes and dislikes.

Th1s study 18, however, to be of the theorles apart from the oriticism, insofar as this is possible. Due to the fact that Schlegel usually developed his theorles from orlticlam of works of literary art, lgmoring his critical writings will be impossible. It will be clear, however, that there is a distinct body of 1deas that can be called the literary theories of Auguat Wilhelm Sohlegel. The reasons for studying these ideas are many.

First of all, Sohlegel's theorizing on ilterature 1s a model of what literary theory should be. It is true that he sometimes, espocially in his earlier writings, wanders off into vaouous speculation and groundless abstractions. For the most part, however, his theorizing will be seen to be solidly based on literery facts, on literary history and his own critical examination of I1terary works. Sohlegel's poet1ce are worth reading for their exemplary conoern w1th literature and not juat with the abstract 1dea of poetry. Here too is the basis of a olaim that Sohlegel individualized what he borrowed, for the great majority of his borrowings are from writings which dealt with art in the abstract. Sohlegel ties 1deas to the practice of oritiolsm and the historioal study of ilterature. His theorles are pragmatic (and those he 
borrows become so) in the sense that every idea is ult1mately proven by 1ts usefulness in explaining literary facts.

Schlegel should not be called a philosopher. Many more prosalo names sult him far better, among them soholar, critic, historian and belletrist. All of these names are for a man distinguished not so much for philosophio genius as for the aomprehending, broadening and communioating of a oultural tradition. When speaking of the scholar's interest in Schlegel's theoretical writings, it must be recognized that to some extent they are only a secondary source for the study of German Romantiolsm. On the other hand, these writings gain importance when we conslder their cioseness to the romantlo movement. Sohlegel was not only a scholar of romantic poetry but also a romantic scholar. His theories must be considered as one of the first soholarly formulations of the romantio view of art, but one close enough to the origins of this view that Schlegel must be considered along with 1ts originators. The closeness of Schlegel's theorizing to his oritlclam must be mentioned again. Ilterary oritiolsm was one of the more important means whereby he and his contemporaries promulgated their new poetlo doctrines. Schlegel's oritiol sm and 1ts theoratical foundations cannot be Ignored in any study of the history of the growth and spreading of the 1dea of romantic poetry. Moreover, it 
14.

should be noted too that the bulk of h1s theoretical writings was first in the form of lectures and the rest appeared in widely read joumals of his time. Schlegel's main aotivity in the decede which concerns us most (17981808) can be characterized as propagandizing for a view of art in which romantic poetry's claims to artist1c worth were fustified alongside those of the classic. We are dealing with important documents for the history of 1deag.

Finelif, it must be remembered that when 1deas are influential. on artistic and cultural facts, their development becomes more than a matter af mere historical record. Schlegel's answers to a numbex of timeless questions w1ll be considered throughout this study. It should be mentioned here, however, that one such question is that of art's freedom from the constraints of the non-aesthetic, real world. The problems of extreme aestheticism are central to Sohlegel's poet1cs. From Kant came the argument, all important for systematic aesthetics, for the autonomous, non-teleologioal nature of aesthetio experience. Romantic theoriats, with the philosophic ald of post-Kantian 1deal1sm, argued further that the artist 1s autonomous in the at of creation. At first poetry 18 freed from classical rules and eventualiy it is feed from virtually all rules. The arguments for such freadom, the nature of 1 ts limitations and the problems arising from denying any 
15.

Iimitations are matters considered by Sohlegel. These are perennial questions facing any modern poetics. Fven when we leave his historical importance out of our conslderation, Schlegel deserves to be read, for many of his arguments bear on living 1ssues.

The foregoing arguments for the importance of Schlegel's theoretical writings have the oharacter of a defense. The defense is, of course, against the arguments of those who have dismissed Sohlegel's literary theories as unimportant on the grounds that they are only restatements of the 1deas of more original thinkers. Oondemnetion to the near oblivion of belng mentioned as a disclple, while his own works are not read, is hardly just. Nevertheless, there is some fustification for the charge againgt Schlegel's originality. In the course of this study we will find a number of elements in Schlegel's theorles which are borrowed from Herder, Kant, Schlller, Fichte, Schelling and Friedrich Schlegel, to mention only the most important influences on Schlegel.

Herder and Auguat Wilhelm Sohlegel share many tastes and dislikes and there are many olmilarities in their writings attributable to unconsolous affinities more than to borrowling on Schlegel'a part. Schlegel did, however, borrow elements of Herder's theorles of language. It seems probable, moreover, that Sohlegel's reading of Herder influenced h1s interest in natural poetry, his 
dislike of pseudo-clasglclsm, h1s repudiation of the traditional doctrines of the dramatio unities and his demand for orfticlsm and theorizing within a hlstorical framework. Schlegel is a follower of Herder in the promotion and actual writing of universal literary history. Kant's 1deas of genius and the sublime (das Frhabene) are the starting places for Schlegel's disousglons of these subfects. More important, however, is the fact that Schlegel was Influenced by the whole Kantlan philosophy. In disaussing the content of literature and 1ts being percelved by an audience, Schlegel frequently concerms himself with the forms under which the mind is able to experience art. He deals with the problem of freedom versus necessity both within art and in the artist. Sahlegel is often at pains to show the autonomy of art.as a subject of philosophical speaulation. A constant theme 1s the problem posed by the 1dealists of the role of art in man's apprehension of reality. Binally, Schlegel is frequently ooncerned w1th the notion of 1deality, the union of the spiritual and phyoleal in art and with problems of dialectic in general, how a higher synthesis arlses from the union of opposites.

In some respects Kant's influence on Schlegel ceme through the mediation of Schiller who offered praotloal examples of how Kant's philosophy could be applied to fundamental problems of poetles. Sohiller more often 
offers the oocasion for Schlegel's speculation rather than a source for his 1deas. We will see that the most important borrowing from Schiller is the idea of the struggle of Natur and Gelgt resolved in art. The 1dea of play and the free aativity of the artist is also from Schiller. Novalis is rarely mentloned by Schlegel. Perhaps he was influential in the development of Sohlegel's 1deas of the all-pervasive powers of Poesie in life and of the relationshlp of 11terature, philosophy and religion. Schlegel's ooorsional approaches to a mystio view of poetry seem to refleot Novalis. Other common tralta are a reverenoe for the powers of language and a notion of g. poetic world whioh is governed by its own laws.

More influential among the men of Sohlegel's generation were Fichte and Schelling. Fichte's doctrine of the ego's oreation of the world is tied to Schlegel's theorles of language, the mediator of all. consclousmess and the medium of Poesie. Through language Fichtean philosophy is related to ilterature. More will be said of this later. Sohelling is of greater Importance. Obvious parallels in the writings of Schelling and Schlegel are the 1dentification of Poesie and philosophy, the ldea of art as an intultive mode of cognition, the analogy of natural and artiatic creation, the relating of myth to literature and, related to all the foregoing, the ldea that art alone an penetrate to the essential nature of the universe. These 
are all subjeots which will be consldered in detall in subsequent ohapters of this study.

Parallels in the theorles of Friedrioh and August Wilhelm Soblegel are countless. An inconolusive collation of the Berlin Lectures w1th Friedrich's prevlously pubI1shed works 1s given by Minor in his prefaces to the lectures. Friedrich's theorles will be discussed at several points in the chapters whloh follow.. Auguat W1Ihelm is in general agreement with Friedrich. On many occaslons, however, such as his discussions of "Poesle der Poesie" and of the "Potenzierung" of poetic expression, he develops phrases from Frledrich into extended arguments. On several important questions (aesthetiolsm and the role of myth in literature, to mention two examples) August Wilhelm seems to disagree w1th Friedrioh elther in principle or in emphasis.

Schlegel quite often declines to mention in his writings the men who obviously influenced his thinking. Kant, it is true, is discussed at some length in the Berlin Lectures. But usually Schlegel's Kantlan borrowings are worked into his leotures without commentary on their source. In the ase of kant such a procedure is just1fled by the asoumption that the references were completely obvious to his audience. His fallure to mention Herder has less justification. It is probable that Schlegel had no desire to have h1s own theorles associated w1th those 
of Herder and the Sturmer und Dränger. Schlegel crit1cizes the writers of the Genlezelt on several occasions. The coldness between the Schlegels and Schiller, occasioned largely by Friedrich and daroline, is a partial explanation for Sohlegel's later fallure to mention Schiller's name in places where it seems to be called for. In the case of Fichte and Schelling the assumption, as in the case of Kant, seems to be that Schlegel's audience was entirely aware of the philosophical sources of the theories they heard propounded. We should not forget the fact of Schelling's presence in Jene and that of Fichte In both Jena and Berlin during the time of Schlegel's activities in those cities. These men were at the height of their popularity and Schlegel could a ssume a common knowledge of the source of those elements of transoendental philosophy which he appropriated in his theorizing.

On occasion August Wilhelm even quotes literally from Friedrich Schlegel without mentioning the source. One is led to believe that neither of the brothers hai a very strong sense of intellectual property in their relationshlp to each other. An admirer of August Wilhelm might be led to suspect that many of Friedrich's 1deas were borrowed from his brother or perhaps to speculate on the extent to which their 1deas were worked out in common. Unfortunately, the documents to support suoh speculations are lacking, for August Wilhelm's letters to Friedrich 
20. were destroyed and the letters of Frledrlch are inconolusive on this point. The loss is especially lamentable for the early format1ve years when the brothers were separated and all literary and philosophlo communication was by means of letters. The unfortunate fact remains that in the case of shared 1deas prior publioation was usually by Friedrich, and so Auguat Wilhelm forever remains subject to the accusation that he wa the commentator on thoughts orlginated by h1s brother. The most convinoing defense of Augrat Wilhelm in cases where the two are in olose agreement seems to be an observation of the way the 1deas involved are colored by h1s own personality. This is the approach of Wellek when he atresses the elder Schlegel's objectivity, sobriety, care in expression and strict consideration of h1storical and 11terary evidence. 8

The accusation of ecleatlolsm cannot be wholly denled. Sohlegel's claim to be read in spite of thls has been stated previously. Many of his concluslons, as we will see, are original. He arrives at further important formulations based on borrowed premises. His works are of admitted historioal importance. Many of his statements, furthermore, are relevant to perennial problems of l1terary theory and oriticism.

The preceding statement of Schlegel's affinlties w1th

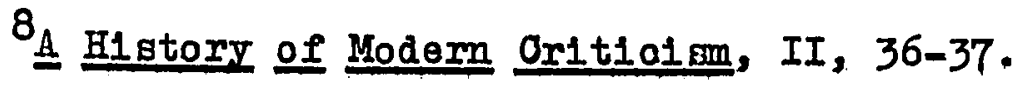


contemporary philosophers is not intended to suggest that he was primarily an aesthetiolan. Schlegel was a critic and historian as well as a theorlst of I1terature. His theories cannot be taken for an attempt at a systematio revelation of the nature of literature. Rather they are both the foundation and the result of the practical endeavors of judging literature and writing 1ts history. Schlegel upholds the interrelatedness of theory, history and criticism both in practice and in theory 1tself. A distinctive feature of his poetic theories is his constant concern for their compatibility with the facts of history and their usefulness in the practice of literary criticism. Although these subjects will be dealt with in more detail later, It will be useful to outline here schlegel's view of the relationship of history, criticism and theory. Iiterary history is vital to both theory and criti01sm. H1story gives to theory the objects on which it must base 1ts conclusions. Oriticism, Schlegel observes, 1s largely a matter of judging the merit of one work in comparison with other related works (Berlin, I, 26). History gives to criticlom the knowledge 1t needs of excellent works of all ages.

Iiterery critiol sm is related to both theory and hlstory. At one point Sohlegel observes, "Dle kritische Reflexion 1st elgentIlch ein beständiges Experimentiren, um auf theoret1sche Sätze zu kammen" (Berlin, I, 27). On 
the other hand, 1t 18 only through orit1o1 sm that works are judged worthy objects of art history and henoe of theory.

Theory serves both history and orlticlsm. History without an organizing idea is meaningless. Theory, sars Schlegel, gives history the 1dea of art and thereby makes of 1t more than a meaningless collection of faots. An Important example 1s seen in the history of anoient and moderm I1terature. Schlegel holds that only theory can reconoile the artistio claims of classic and romantic art (Berlin, I, 22). Finally, critical fudgments must be more than mere expressions of opinion. Fxpression within a convinoing system is a means whereby the validity of Judgments can be maintained. Theory gives oriticism such a system w1thin which 1ts judgments can be expressed.

These statements by Schlegel on the relationship of history, theory and crltialsm reflect the nature of $\mathrm{his}$ own work. Ilterary history, when written by Schlegel, is never a I1feless chronicle but is uplifted by theoret1cal statements and critical insights. His critlolsm 1s based on a broad knowledge of literary history, and criticiam leads to some of Schlegel's most important theoret1oal statements. Finalig, and most important, thoory is never wholly separated from history and critiolm. Schlegel's most Important borrowings are from thinkers more abatract than himself: Kant, Fiohte, Schelling and even Friedrioh 
Schlegel. Auguat Wilhelm Sohlegel's achlevement lies partly in his original ingights and partly in his bringing the inslghts of others to bear on practical orltical and h1starical problems. The most important of these is the question of modern literature's claim to artistic merit. The success of Schlegel's endeavars will be considered further in this study's concluding chapter. 


\section{OHAPTER II}

THE SPEOUIATIVE HISTORY OF POETIO ORIGINS

In his "Briefe uber Poesie, Sylbenmap und Sprache" (1795-96) Schlegel observes, "Indem man erklärt, wie die Kunst wurde, zelgt man zugle1ch auf das elnleuchtendste, wes sle gein soll" ( $\underline{\mathrm{SW}}, \mathrm{VII}, 107$ ). Herder 1s Schlegel's model in this approach to the nature of art. It should be noted, however, that Schlegel had some reservations about the value of such a procedure as h1story. He later admits that there are no historical data to support the Ideas which follow and that, in fact, their only proof is a philosophical one. This admisgion seems to suggest that the "should be" of postry could just as easily be determined without the intermediate step of history. In fact, the context of the statement quoted above implies that one of the justifications for the pseudo-history whloh follows is to:'make art theory more palatable to those who doubt its worth. Historical speculation could convince where a more abstract approach might fall. History 1s here merely the form of Schlegel's I1terary theorles.

Schlegel 1s concerned to show Poegle to be a necessary outgrowth of human nature. Man's nature 1s twofold: phys1orl and spiritual, IImited and free. The reconolilation of these two aspects of man ooours in art. This thought 
25.

1s an outgrowth of Schlegel's reading of Kant and Schiller, but in the "Briefe" the argument is not to be a philosophlcal one but rather historical and even anthropological, based on the supposed nature of primitive man.

In the "Briefe" Schlegel argues that man's memory causes an accumulation of feelings and passions. The inner tension of emotion brings about the urge toward expression. The most natural means available are vocal tones and movements of the body. But memory allows so great an acoumulation of emotion that simple cries and movements are Inadequate to express 1t. Bodily IImitations are such that man could exhaugt himself, even destroy his body, in an attempt to express himgelf fully. The way out of the dilemna Iles in rhythmic movements and rhythmic articulation of volce. At first this is a matter of necessity rather than of aesthetic intent. The body can work more efflclently if it works rhythmically, and this efflciency 1s necessary for the expression of man's accumulated emotions without exhausting his body in the process.

Man discovers rhythm in h1s own breathing and heartbeat and applias the principle to volce and gestures. There results the orlginal form out of whlch all art grows, an expression of emotion through a combination of song and dance. In the beginning poetry, muslo and dance were comblned. Th1s disciplined exercise of freedom answers the needs of both sides of man's nature and offers the most 
26.

striking example of how art is natural to man.

Rhythmic sounds and movements were, then, orlginally a human necessity. The stages in the development of the necessity into an art are these. At first the expression was of an 1mmediate emotion and was forgotten after it was completad. But in expressing emotions, man sensed a certain mastery over them and so song became a civilizing influence. Songs were worth remembering and passing down from generation to generation. On the other hand, since men were subject to the same environment which occasloned similar emotions in them all, it was only natural that they should express these emotions together. Again it was rhythm which brought out of a cheos of individual expressions the order of communal song and dance. Acting together with other men brought about a more conscious choice of the outer forms of expression. Oholce 1s governed partially by another basle human disposition; that of beautifying the useful with pleasing decoration. This beautifying is fundamental to art:

Im Wohlgefallen an vermelntlich schönem Zlerrat, und in dem Vermögen der Finbildungskraft, inn zu erfinden, liegen die edelsten Kinste, die sich je unter geistrelchen Volkerm bis zur Relfe entfaltet haben, wie in 1hrem Keime beschloßen. (SW, VII, 151)

When expression became an object of pleasure, 1ts repitition พas also pleasant. So man sang and danced even when the emations, the need which occasloned the express1on, were past. The result 1s this: 
Nun erst wurde also Tanz und Gesang als Frgötzung getrieben. Fs muste endlioh dahin kommen, das man sich durch Hilfe der Phantasie frelwillig aus elnem ruhigen Zustande in lebhafte Regungen versetzte. So entstand elgentliohe Dichtung; so Kam Nachahmung zum Vorschein; denn alles Vorhergehende war reine, unverm1 sohte Wahrheit gewesen. (SW, VII, 152)

The word "Nachahmung" is used here to denote the imltation of emotional expressions when real emotions were no longer present. The subject of mimetic theory will concern us later when Schlegel uses the term in a mare traditional gense. Here he 1s only saying that art was born when an activity whlch was previously a necessity became free creation and, In Schlller's sense, play.

Originally the arts of poetry, music and dance were combined. If we congider only the poetic element in this combination, it is apparent that the earliest poetry was Iyric, that 1s, the outpoured expression of emotion, at f1rst of emotion ocoasloned by real clroumstances and later also emotion aroused in imaginative re-oreation. With the birth of art as a free activity, making poetry gradually became a skill practlced by a gifted few rather than something which all men had to do.

Sohlegel's flrst prinolple of dividing the axts is based on the Kantian categories of space and time. In the Berlin Lectures he says,

Die Kinate treiben ihr Wesen in Relch der Fracheinungen, sie stellen sinnlioh dar. Nun giebt es aber zwey Pormen der sinnlichen Anschauung, Raum und Zeit. Darnach lassen sich zwey Gattungen von klinsten denken, solche die simultan und die successi.t darstellen. (Berlin, I, 112) 
28.

Schlegel further classifles according to natural modes of expression. The primary successive arts and their means of expression are music (tones), dance (gestures) and Poosie (Ianguage). This leads us to the subject of language.

In the "Briefe" language is a subject of relatively minor importance. There Schlegel sought to find the natural orlgins of poetry in rhythm. In his lectures in Jena and Berlin, however, he widens his search for natural origins. He is conoerned to show how art develops from fundamental human dispositions and Poesie is seen to grow naturaliy from the original nature of a mode of expression as old as man himself. This is language.

In the "Brlefe" Schlegel calls language "die wunderbarste Schöpfung des menschllchen Dichtungsvermögens, glelchsam das große, nie vollendete Gedicht, worln die menschliche Natur sich selbst darstellt..." (SW, VII, 104). Here 1s another perspective on art as the speciallzation in an ablilty which originally belonged to all men. Originally all language was by nature poet1c. In time 1t lost that quality. The poet, however, restores poetry to language.

The Jena Lectures state that one aspect of original language which makes it poet1c is 1ts use of comparisons: "D1e Frwelterung der Sprache setzt eine ununterbroohene Kette von Verglelohungen voraus; die friheste Spreche 1st 
daher Im höchsten Grade trop1sch: und bildlich, d. h. poet1soh" (1798, p.23). Th1s thought 1s found in Rousseau but 1ts development by Schlegel 1s along more 1deal1st1c IInes. It is man's understanding which destroyed the essential unity of mind and the senses and it is art which restores that unity. The poetry in Urspreche lies in the fact that there is reflected there the same sort of harmonlous working of man's facult1es which, according to Kant, occurs in aesthet1o experlence. This 1s true, says Sohlegel, because the first men who spoke were trying to ploture objects and feelings with words. Words were not merely understood but rather evoked mental images like those aroused by the objects to whlch the words referred. Orlginally language was not an objeot of Verstand but rather of Imagination in the sense of image-making. "Understanding" words marks a degeneration of language. Schlegel constantiy reminds us that the appeal of Poeg1e 1s to 1magination. Here we mugt note the word "Image" in Imagination, the B11d in Elnbildungakraft. An appeal to Imagination was also made by orlginal language. Th1s is another evidence of its poet1c nature. Prose was a later development wherein words lost their B1ldilobke1t and beoame merely conventional signs which spoke not to the imagination but to understanding. The poet reatores the poetic quality to language, a quality whlch, however, language never completely loses. The restoration of 
30.

language's original nature also occurs to some extent in sohone Prose which, however, is bound to the laws of common usage while Poegle follows only 1ts own laws.

Sohlegel makes a distinction between Naturpoesie and Eunstpoesle which, in the Jena Lectures, remains rather poorly defined. Homer seems to be the dividing line, belonging to both categories. But Schlegel adds, "Auch könnte man . . die ganze grieohische Poesie elne Naturpoesie nennen, well der Trieb, nicht die Kunst in ihr herrscht" (1798, p.29). In the Berlin Lectures he sees the appearance of the genres as the beginning of I1terary art. As for Naturpoesie, Schlegel sees it in three a spects:

Beym Heranwa ohsen der Naturpoeste können wir folgende drey Stufen oder B1ldungsepochen unterscheiden:

1) Filementarpoesle in der Gestalt der Ursprache; 2) Absonderung der poet1schen Successionen in unserm Innern von anderwe1tigen Zustănden durch eln äußeres Gesetz der Form, nämlich den Rhythmus; 3) Bindung und Zusammenfassung der poet1schen Flemente zu elner Ansicht des Weltganzen, Mythologie. (Beri1n, I, 268)

In the Berlin Iectures Schlegel still gives his -speculations a semi-historical form but he has become more philosophical. He adds to the above discussion of the aspects of Naturpoesie:

Die Sprache 1st von 1hrer Entstehung an der Urstoff der Poesie; das Sylbenma (Im weitesten Sinne) die Form lhrer Realitet, das äußerliche Gesetz, unter welohem sie in die Welt der Erscheinungen eintritt; die Mythologie endlich lat glelchsam eine Organisat1on, welohe slch der poetlsohe Geist aus der elementarischen Welt anbildet, und durch dessen Medium, mit dessen Organen er nun alle Ubrigen Gegenstende anschaut und ergreift. (Berlin, I, 269) 
31.

This sohematism of Stoff-Form-Organisation goes beyond the hiatorical and anthropological foundations of his earlier writings. Sohlegel does not, however, completely forsake the approach through Urgesohlohte. He found the problem of Stoff vs. Form formulated by Kant and Sohiller but the relation of the problem to historical origins results in the 1dea that not conscious art but rather myth was the first union of matter and form in an organized view of the world.

Although Schlegel never adopted Fichte's system as a whole, his influence is evident in the speculations on language in the Berlin Lecturea. In perticular, we find Schlegel identifying original language with man'a firgt formation of the 1dea of an orderly world apart from the self:

Das selbst thätige Prinzip nun, welches der thierischen Abhänglgkelt entgegengesetzt 1st, mecht alch nur deduroh geltend, dap es Zusammenhang und Finheit in das Daseyn zu bringen sucht. Fs vergleloht also die sinnilohen Findricke mit einander; um vergliahen $z u$ werden, müssen ste coëxlstiren, dieß setzt folglich die Fahigkeit voraus, Elndrioke festzuhalten. Darin besteht nun eben das ursprïngliche Sprechen. (Berlin, $I, 275)$

Later we will find Sohlegel even more strongly influenced by Fichte. Here, however, the historlcal-anthropological approach is more evident. The stress on the importance of memory comes from Hemsterhuls and Herder, as does his argument that in the beginning thinking and speaking were 1dentical. The sign around which experience is organized 
does not have to be spoken, although there is an urge toward expression: "Das Sprechen 1st . . zuvôrderst eine Innerliche Handlung, d1e slch aber unfehlbar dem Körper mitthelien und als Bewegung zum Vorsohein kommen wird" (Berlin, I, 275). Sohlegel oalls the orlginal function of language 1ts use ag "Gedanken-Organ."

At this point Sohlegel indulges in further speculations on the psychology of primitive man. According to Schlegel, man first tested words on himself in order to. Judge their effect on others, whence the use of volce to express the "1nnerliche Handlung" spoken of above. Volce wes the only means of outer expression whlch man could percelve in its totality and which would thus allow him to Judge adequately the success of his attempts. Perhaps gestures orlginally plajed a larger role, but eventually volce won the upper hand, for the reason fust stated and because it appeared to come from within where the signs man sought to express seemed to 110 .

The importance of these thoughts lies in their expansion of the idea of imitation of emotions whioh we found in the "Briefe." Here 1t 1s not just emotion but all of man's mental functions which are expressed. Orig1nally language consisted of natural signs, that 1s, it was an ifmitiatlon of something going on inside man. "Die Ursprache - . Wird aus natillichen Zelohen bestehen, d. h. aus solchen die in einem wesentlichen Zusammenhange 
mit dem Bezelchneten stehn: denn sie besteht in Bewegungen der Sprechwerkzeuge welche duroh innre Affectionen veranlapt werden" (Berlin, I, 277). Again Schlegel 1s far from promoting a traditional mimetic theory. What language expresses is not objective nature but rather man's experience of 1t. Sohlegel oalls language "elne umblldende Darstellung" (Berlin, I, 278), by which he means that in portraying something in words it is re-formed by 1ts being experienced by man.

It would seem that language, appealing as it does to the sense of hearing, could form natural signs only for impressions made by things heard. But analogies between sense Impressions are felt and these are expressed. Hence the sounds of words can express impressions of sights, things felt, and so on. Schlegel observes,

Die Frwelterung der Sprache setzt also schon in der sinnlichen Region eine ununterbrochne Kette von Verglelchungen voraus. Allein der Mensch mus dehin kommen, auoh dasfenige durch Sprache bezelahnen zu wollen, was in keiner sinnlichen Ansohauung gegeben werd en kann. (Berlin, I, 279)

How are such things expressed? Sinoe man always has int1mations of the essential inseparableness of mind and body, 1t is only natural that he should express the abstract, his own non-sensual functions and things never actually experlenced by the senses, in physiaal terms. This forming of words for things not physically experienced is one of the first signs of the birth of Poesie:

Es baut sich nun also in der Sprache luber der ersten 
34.

Darstellung der Sinnenwelt elne zweyte unsrer unsinnI1chen Anschauungen, und das Band zw1schen beyden 1st die Metapher. Die Bildliohkelt, das Bezelchnen durch Vergleichung, trat zwar schon in jener ersten Sphäre ein, aber hler thut sich erst das volle Bewuptseyn des symbolisirenden Vermögens in uns hervor, duroh dessen willkuhrlichen akichtlichen Gebrauch alsdann aus den poetischen plementen der Ursprache elgentliohe Poesie gebildet wird. (Berlin, I, 280)

As long as man was trying to express 1mmediate experience his words were merely unconsclous reflections of that experience. But when the expertence was no Ionger 1mmediate symbols could be found only by consclous effort. Conscious symbollzing, as we will later find schlegel arguing In more detall, is fundamental to Poesie.

Schlegel sees another aspect of Ursprache in personification. Again his argument is psychological. The ultimate source of personiflcation lies in human nature:

Der Mensch erfindet die Sprache nicht als ein milig beschauendes Wesen, sondern als ein solches welohes unter dem Andrang der physischen Kräfte selne Existenz zu behaupten sucht. Das bewegte, s1ch verändernde, sichtbar wirkende wird ihn also zuvörderst und weit gewaltiger treffen als das Ruhende. (Berlin, I, 280)

Which leads to this conclusion:

Da nun der menschliche Geist zuerst auf W1rkungen gerichtet 1st, und ehe er den Grund 1rgend einer fremden Wirkung einsleht, den Grund derer, welche er selbst unmittelbar in s1ch fuhlt, so stelit er slch alle Veränderungen unter dem B1lde selner eignen Wirkungsart vor, d. $h$. als durch einen Willen bewerkstell1gt, als Handlungen. (Berlin, I, 281)

Bventually man anthrupomorphizes all nature and thls is the basis of mythology.

We are now in a position to survey Schlegel's arguments 
concerning the relationship of language to poetry. Ianguage is in essence poetic. By 1ts very nature it involves a close correspondence of sign to yhat is designated; 1t deals in tropes and metaphors; it personifies; It is bildilch or "Imaginative" in the sense that it expresses and re-creates 1mages. Prose, as we saw, marka a degeneration in language wherein images turn into concepte and words are no longer "Imagined" but are merely understood. The correspondence of sound to meaning is 1ost. And understanding pays less attention to words and their meaning, agr Schlegel, than to thelr combination in logioal sequences. The ultimate result is this:

Die Ableltung der Worter wird durch den Verlauf der Ze1t unkenntilch, 1ndem sie selbst sich naoh der Bequemlichkeit der Sprechenden riohtet, jene Symbolik, Jener allgemeine Schemat temus der Pantasia, muß den strengeren aber todten Bestimmungen des Verstandes welohen: und so wird im Fortgange der Cultur die Sprache aus einer Finhelt lebendiger Bezel chnung in elne Sammlung willkihrlioher conventloneller

Zelchen verwandelt erscheinen. (Berlin, I, 282)

The process 1s, however, never complete and there are always traces of Neturpoes1e in all language. On the other hand, the degeneration of language is fully reversed only by the conscious effort of pushing beck the purposes which reduced it to a mere means to an end. This ooours in Bohöne Prose and above all in Kunstpoesie.

The second element of Naturpoesie is rhythm, a basic definition of which is found in the Jene Iectures: "Der Bhythmus ist die Anordnung elner Reihe von Bewegrangen in 
der Zeit, woduroh Verhaltnisge unter derselben wahrgenommen werden können" (1798, p.74). Mater 1s defined thus:

"Motrum 1at das Ganze einer Reihe von Rhythmen, der Rhythmik in der 2. Potenz" (1798, p.75). We have already noted the origin of rhythm in physicel necessity. In Schlegel's words,

Die Seele, von der Netur allein erzogen und keine Fepeln gewohnt, forderte Freihe1t in inrer alupern Verikindigung; der Korper bedurfte, um nioht der anhaltenden Heftigke1t derselben zu unterliegen, ein Maß, worauf seine innre Elnrichting inn fuhlbar le1tete. Fin geordneter Bhythmus der Bewegungen und Tơne vereinigte beldes, und darin lag urepringlich seine wohlthätige Zaubermecht. (SW, VII, 139)

We have already seen that, once discovered, rhythm and 1ts effects were enfoyed, and eventualiy it was used in the expression of inventions of Phantagie, whence the birth of Diohtung, that 1s, of poetic fletions.

Sohlegel also looks at rhythm and meter from the perspective of expression. Summing up his statements on rhythm in the Berlin Lectures, he says,

W1r zelgten nämlich daß dieser, den man als den geordneten Wechsel in der Successionen definiren kann, in der Finen unthe1lbaren Urkunst, die zugleich Possie, Musile und Tanz 1st, elne Combination des Charakters unsrer willkihrilchein Funktionen, und unsrer organischen Verrichtungen, eine Darstellung des Beharrliohen Im Weohsel der Vorstellungen sey, und also die succeselven Khnste zum Ausdruck unsrer gesamten geistigen und körperliohen Natur, des Lebens und der Persönliohke1t maahe. (Berlin, I, 315-16)

Th1s is the point of View whioh allows Sohlegel to devote so much time to metrical technicalities, explaining the use and appropriateness of every known metrical device, 
every kind of strophe. Some of these teohnicallties will concern us when we consider the genres.

Later we will examine Sohlegel's view of Poesie as a world in itself, a flotion distinguished from ordinary reality. Here let us note that one of the functions of meter is to set Poegle apart from the real world, especlally from the time of the real world. Sohlegel follows Kant in maintaining the non-teleologioal nature of art. In Schlegel's speculations this cherecteristic is related to the flotional nature of Poesle which presents a world complete in 1tself. In the Berlin Lectures, for example, Schlegel has just noted the tendency of prosalc speech to depart from the musical when he goes on to say,

Dag Streben der Poegie iat nun ein gerade entgegengesetztes, und folglich um anzukindigen, deß sie eine Rede sey die lhren Zweck in sich selbst hat, dap sie keinem aupern Geschifte diene, und so in die anderweitig bestimmte Zeitfolge eingreifen will, muß sie sich lhre Zeitfolge selbst bilden. Nur dadurch wird der Hörer aus der Wirklichke1t entrlakt, und in elne imaginative Zeltrelhe versetzt, da $\beta$ er in der Rede selbst eine Gesetzmëp1ge Finthellung der Sucoessionen, ein Zeitmas wahrnimmt; und daher die wunderbare Frschelnung dap die Sprache grade in ihrer freyeaten Frsoheinung, als blopes Spiel gebraucht, sich des sonst in thr herrsohenden Charakters der W1llkelhr freywlilig ontalusert, und einem Ihrem Inhalte acheinbar fremden Gesetze unterwirft. Dieses Gesetz 1at das Zeltma, der Takt, der Rhythmus, Welchen die Poesie in ihrem Ursprunge mit der Muglk gemein hat.. - Was nach der bey der welteren mtwlokelung beyder erfolgenden Soheldung dieser Kunste in der Form der Poesie zurilakble1bt, ist das Sylbenmaß . . * (Berlin, I, 117)

So the metrioal form of Poegle was originally what separated it from other linguistio utteranoes, and meter remains 
38.

one of the elements whlch sets the created world of literary art apart Irom the real world of ordinary experience.

We now turn to the third element in Schlege.L's theory of Naturpoesie. Myth plays a double role in Sohlegel's poetlo theories. It is the first union of poetio matter (language) and poetlo form (meter) into complete poetic structures. Furthermore, myth 1s a source of inspiration and poetlc material for later art1sta. The subject of a new mythology for modern times is only touched on by Sohlegel, and this fact requires some commentary before we proceed.

The hope that poetry might be revitalized by a rebirth of mythology had been expressed before Schlegel, notably by Klopstook, Herder and Schjller. In the Ilght of Frledrloh Schlegel's well known vlews on this subjeot, it 1s surprising that Auguat Wilheim does not lay great stress on the importance of a new mythology. The subjeot does not, however, go unmentioned. At one point in the Berlin Leatures (III, 86) he seems to take it for granted that all I1terature must have a mythological basis and that the myths muat be more than a dead heritage. In another place in the same leatures, however, he suggests that the absence of myth is characteriatic of modern literature. At the end of the first serles of Berlin Lectures he speaks of new comedy as the first genre in which mythology was completely absent. This 1s followed by the 
39.

fragmentary note "Anfang des Modernen" (Berlin, I, 355).

Priedrich Sohlegel, in hig "Gegprëch Uber die Poesle,"

had earlier characterized modern poetry by 1ts lack of

myth:

Aus dem Innern herausarbelten das alles muß der moderme Diohter, und viele haben es herrlich getan, aber bis jatzt nur jeder allein, jodes Werk wie elne neue Schöpfung von vorn an aus nichts. . . Fs fehlt . - unsrer Poesie an elnem Mittelpunkt, wle os fur die der Alten war, und alles Wesentliche, worin die moderne Dichtkunst der antiken nachsteht, läßt s10h in die forte zusammenfassen: Wir haben keIne Mythologie.1

Friedrich goes on to describe the possibilities for a new mythology. August Wilhelm does not undertake to do this. We sometimes find him wishing for such a modern mythology to replace the anolent myths which are, for us, no longer living. But there seems to be little one can do to further the birth of such myths since, he seys, "Eine Mythologie kann ebensowenlg die willkirliche Frfindung eines einzelnen sein als dne Spraohe; daher auch alle in dieser Art mit so großem Aufwand von Ge1st und Finbildungakraft gemachten Verguohe mißgllloken mußten" (1798, p.111). He makes special note of the failure of klopstook and kilton in this endeavor. At worst, such undertakings degenerate into superficial allegory.

The above passage from Friedrloh's "Gesprä oh uber die Poesie" 1s noteworthy for 1ts stressing the burden imposed

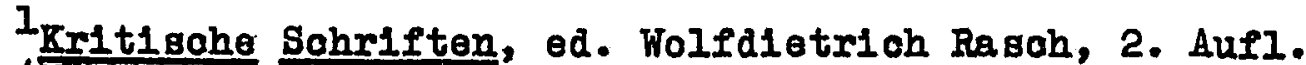
(Munohen, 1964) p.497. Hereafter referred to as Ragoh. 
on the modern poet by the lack of IIving myths. We will see that this lack is not so strongly felt by August Wilhelm. Mogt of his discussions of myth are of 1ts role as Neturpoesie. Myth is a poetic view of the world and as such has many elements which can be borrowed by Kungtpoegle: Iiterature 1tself, however, is a poeticizing of the world and it oan aocomplish this end without the mediation of myth.

For August Filhelm it is phllosophy more than myth which provides a basis for modern poetry's claim to being more than pure subjectivity. He follows Schelling and Iovalis in maintaining that philosophy and poetry have the saria aim. On the other hand, myth and Poeg1e are also related through phllosophy for Schlegel also take from Schelling the thought that myth is philosophy in the realm of the objectively real. Insofar as Poesie philosophizes symbollcally, it acoomplishes in the form of consolously contrived fictions what myth does unconsclously in objective reality. Myth 1s not art. It can be used by art but evidently does not have to be.

The thought that myth, like art, is a product of creative Imagination was a oommonplace by Schlegel's time. Flahte's 1dea of the oreative ego allowed a further extengion of this thesis. Sohlegel stater that it 18 Phantagie which posits the objective and the subjective world and from this thought he procedes to define myth's position 
in a dialectioal soheme:

Der urspringlichste Akt der Fantasie 1st derjenlge, woduroh unsre elgne Bristenz und die ganze Aupenwelt fur uns Realitat gewinnt. Das diese ein Produkt unsrer elgnen Thittigke1t sey, kann jedoch nur durch speculation dergethan werden, nie ins Bewußtseyn fallen. Das entgegengesetzte Extrem 1st die kinstlerische Wiriksamke1t der Fantasie, die selbstbewußt 1at, und mit Absicht geleitet wird. Diese 1st in Ansehung 1hrer Produkte rein 1deell, d. h. sie macht fur sie keine Anspruche auf Wirkilchkolt, und bedarf deren nloht. Zwischen oblgen beyden liegt nun die, woraus die Mythologie hervorgeht, in der Mitte. Sie glebt folglich ihren Producten eine 1deolle Realität; d. h. fur den Golst sind sie wirklich, wiewohl sie in der sinnlichen Frfahrung nioht nachgewlesen werden könnon. (Berlin, I, 329-30)

Schlegel goes on to extend the Fichtean argument into the realm of pre-history. Myth comes from an age when the human splrit was not jet divided, when there was not yet a distinction of Phantasie and Verstand. Phantasie ruled man'a I1fe but, without the distinotion just mentioned, it did so unconsclously.

The reality of myth and the flotion of poegle are distinguished. Both are, however, products of Phantagie which acts consclously in pootry and unconsolously in myth. In the following passage myth and poetry are seen to have another quality in common:

Öberall wo die menschliohe Natur sich mit Nothwendigke1t entwickelt, ohne mögliche fingriffe einer fehlerhaften W1llkihr, kann sie nloht 1rren. Die Mythologie 1at oine im Gange der menschlichen Oultur wesentliche, und unabsichtliche Sohzppfung der Fantasie: ea muß 1hr also Wahrheit zum Grunde liegen. Das Fabelhafte 1 st also nicht blok fur wahrhaft gahalten worden, sondern es 1st in einem gewl ssen SInne wahr; je man kann sagen, das in dem Geiste achter Diohtungen alle Wahrheit beschlossen llegt. (Berlin, I, 330) 
Here we see Schelling"s influence on Schlegel. "Alle Wahrhelt" muat be taken literally. Philosophy and poetry express the same truths. Mythology and, as we w1ll see later, history differ from them in the fact that their expressions are in the realm of real events.

Similar to Schlegel's distinotion of Poegle and prose 1s his contrast of a mythic and prosalc view of reality. In the age of myth-making Phantagie ruled without awareness of Verstand. A myth is like a dream: perhaps fragmentary and seemingly incoherent, but the understanding does not doubt the reality of what ocours in 1t. Veratand, fust as 1t is the source of the prosalo in language, is also the souroe of a prosale vlew of the world, the deoline of myth. Poetry 1s an artiatic restoration of the mythioal gtate in the realm of the conscious: "Dle Poesie lat elne kilnstlerlsche Herstellung fenes mythischon Zustandes, ein freyw1ll1ges und waches Träumen" (Berlin, I, 330).

Mytha fulfill the demand made by the 1dealists on art, that 1t combine the materlal and the spiritual. Fridence of this is found in myth's use of the means which poetry uges to the seme end. The most immediately obvious of these 1s personification, but to this must be added virtually all the devices of language found in ilterature, a fact which Schlegel demonstrates in some detall. The following statements exemplify Sohlegel's arguments that myths, because of their poetlc qualities, are supremely 
appropriate for use in poetio art:

Wir sehen .... daß in der mythischen Bezelchnung, eben so wohl wie in denen der Ursprache, die Tropen gelten; und duroh diese in der Mythologie sehr welt verbreiteten Ubertragungen des Sinnlichen auf das Gelstige, wird glelch Anfangs der Grund zu lhrer keinftigen Vieldeutigkeit, und elner Bildsamke1t, die jeder hôh heren Foderung Genlige leisten kann, gelegt. Wie die Mythologie eine Umschaffung der Natur 1st, so 1st sle selbst Ins unendliche poetischer Umsohaffungen empfänglich. (Berlin, I, 336-37)

Presently we w1ll eurvey brlefly Schlegel's views on the development of Greek mythology. Here we note his observation that myths take on new meanings in the course of time. The resulting wealth of their meanings together with their 1magery and the1r Umsohaffungafehlgkelt are qualities whioh allow their borrowing and reworking in higher, consclously created art.

Schlegel distingulshes two kinds of religions and mythologles according to whother they refleot more strongly man's physical or his spiritual side. He calls these two types realist10 and 1dealiatic. The best known realistic mythology is that of the Greeks and 1t 1s around this mythology that Sohlegel's theorles are developed. The opposite 1dealistic extreme is the Ohristian religion. But since man's nature 18, aftex all, indivialble, traces of each of these types appear in every religion and mythology. There are three stages in the development of Greek mythology: the physical, the mystical and the 1deal. These stagea are not sharply separated from each other and they overlap in time, but they do roughly denote the historioal 
44.

progress of Greek mythology.

In the physical myths man personifies the powers of nature, that 18, he explains the workings of the world in terms of his own activities. These physical powers are, however, essentlally unfathomable and are usually immoasurably greater then man's own powers. Their personificationg are accordingly not men, but gods. Moreover, this process of personification does not stop with physical nature but 1s extended to human dispositions, situations, pessions: for example, sleep, death, love, war. The symboIic nature of certain gods often shifts in time so that varioin gods of aotivities become symbols of the products of these activitieg, e. g., Bacchus becomes the god not just of the vintage but also of wine 1tself. Through such processes the gods take on new meanings and more complex relationghipg among themselves. Sohlegel comments,

Auf solche Nelse waren die alten Gotthelten nicht Finkleldungen scharf abgesohnittner und erschöpllicher Begriffe, sondern ele enteprechen volien Massen der Ansohauung, die aus elnem bestimmten Standpunkte fur die Betrachtung der Natur und des

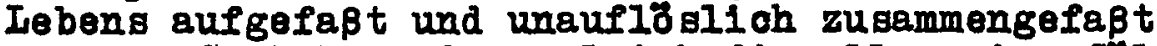
waren. So baben sie zuglelch die allgemeine Giltigkeit von Ideen und die lebendige Gegenwart von Individien. (Berlin, I, 335-36)

We note agein that Sohlegel 18 discugeing myth as Neturpoegie which 18 a historloal predecessor of Kunstpoesie. In myth we can see the birth of a Poegie which is an expression of a complex view of the world. Its qualities are completeness, coherence and vividness. And the gods, we are told, have the valldity of 1deas and the living 
45.

presence of individuals. This is the sense in which poetry as art has both a truth beyond 1tself and yet a I1fe of its own complete within itself.

While the physical mythe portray the world in animate. forms, Schlegel rightly denies that they are allegorical in character:

Ob Homers Mythen allegorisch gemeynt sejen, diese Frage 1 it hâf1g aufgeworfen, und verschieden beantwortet worden. Wenn Allegorie die besonnene und absichtlioh erfundne bildilohe Finkleidung eines Begriffa bedeutet, so muß man es bestimmt verneinen. Jenen Mythen liegt mehr das Pantagiebild zum Grunde welches dem abstrakten Begriffe vorhergeht. Fs sind gegebne Ganze der Anschauung, nicht durch Bestimmungen des Verstandes sonder sinnlioh ungrênzt. (Berlin, I, 338-39)

This too is true of the highest poetry. It is a ray of seeing things, and this seeing 1s the primary act in 1ts creation. Poetry does not arise from the mere casting of pre-exlsting concepts into sensuous forms.

The second epoch of myth's development, the mystic, comes with what Sohlegel oalls the Iirst premonition of the infinite. The mystio disposition tends to concentrate the powers of many gods into one. Th1s stage of mythology deals with secret mysterles and produces gods who stand for all of nature. Iittle 18 sald about the relationship of these myths to 11terature.

The third stage of Greek mythology 18 the 1deal, that 18, the atage wherein the Greeks formed a myth1c 1deal of man. Th1s stage produces gods who represent the perfection of human qualities and ablifties. 
46.

In general, the historlcal relationship of myth to

Poegle 1s one of borrowing by the latter from mythology.

Der Mythus liefert [der Poesie] einen welt mehr zuberelteten Stoff als die bloße Natur: er 1st eine Natur im poetischen Ko stim. Fr 1st selbst gew1ssermaßen sohon Poesie, kann aber duroh eine mit Bewußtseyn freye Behandlung wlederum zum Organ, ja zum bloßen Flement herabgesetzt werden. (Berlin, I, 342)

In the 1798 Lectures Schlegel stated the relationship thus:

Der Mythus 1st, wle die Sprache, ein allgemeines, ein notwendiges Produkt des menschlichen Diahtungsvermő̈gens, glelchsam eine Urpoesie des Menschengeschlechts. Thr die Poesie in höhern Sinne ist er aber nicht Selbstzweck, sondern Mittel zur Brrelchung dichterischer Zwecke, Organ und Medium der Daratellung. (1798, pp.97-98)

In myths the poet finds the world already poeticlzed, and so these can be eas1ly borrowed and used by Kunstpoesie. Myth is not Poesie, that 1s, it is not a playful fiction of an Individual poet but rather a view of man and the world in which the action: is symbolic and jet originally we s ilterally true for the nation to which the myths belonged. Fren the use of mythr in Poesie by simple borrowing 1s Iimited. In the 1798 Lectures Schlegel observes, Der Mythus kann nur da mit Vortell in die Diohtung selbst verwebt werden, wo er lebendig und einhelmisch 1st; sinnbildliohe Ansplelungen darauf setzen voraus, daß ex der Phantasie geläufig ala ghltig anerkannt se1. (1798, p.110)

The conditions prescribed here exist only in flotions set, for example, in the ancient world if it is the Greek myths whioh are to be used. Poetry 1s endangered by inappropriate myths and by I1feless antiquarianism. 
The final stage in the birth of literary art is the transition from Naturpoesie to Kunatpoesie. It was seen earlier that the trangltion is one from the unconsolous fulfillment of a need to consolous creation. The earliest form of Poegle, the Iyrio, is at firgt the expression of an Immediate and pressing emotion. Originally the song died with the emotion. There is a transitional stage in the b1rth of Iyric art where the song is preserved after the emotion has passed away. Finaliy, songs, later poems, are made whioh are occasloned not by present feelings but rather by feelings which are created or re-oreated in imagination. Men who do this are no longer merely obeying a need but are creating art and are doing it in full consolousness of what they are doing.

Th1s ohapter set out to survey Sohlegel's 1deas on. the primordial origins of Poesie. In concluding, it should be pointed out that this speculative history hardiy goes beyond lyrio poetry. The Iyric 1s the only genre of Eungtpoesle whose natural origins are examined, whereas the beginning of literature with character, plot and action 1s not defined. Schlegel tells us why men f1rst sang, but It is not clear why they first came to write eplos or drames. In the Berlin Lectures the answer is perhaps touched on in the following thoughts on the relationghip. of myth and Poeg1e. Schlegel is speaking of the three stages in the development of Greek mythology: 
48.

Wir finden auch diese stufen in den versohiednen Gattungen der Griechlschen Poesie, welche nech der Ordnung ihres Fortschrittes zu einer selbstatindigen Kunat auf einander folgten, deutlioh bezelohnet. Das Tpos ist noch am meisten blok pasaive Uberlieferung des gegebnen. Das Iyrische Gedicht zeigt seine grobere Prejheit in der Wahl der Ansplelungen, berihrt die Mythen oft nur flucht1g, verknlpft, sehr entfernte $u$. s. $w$. Die Tragiker endlich gingen am ireyesten mit den Mythen um, und modelten sie ganz nach ihren Zweoken. (Berlin, I, 342-43)

Schlegel's treatment of myth is his first disoussion of any sort of poetry in which characters and action appear. Here we find him on the verge of saying that myth was the model for Kungtpoesie In 1ts use of these devices. But the point is not pursued and these matters are disoussed outside the context of his speculative history of poetio origins.

In conoluding it should be pointed out that Schlegel's View of myth as Naturpoesie is part of a tradition which I1ves on. In a sense myths are creations of nature, that 18, of human nature working unconsolously. Purthermore, the myths are not oreated by individuals but by mankind collectively, a view elaborated at great length by the soholars of myth and folklore among the later romantica. The terms used above cen be compounded to produce the term "collect1ve unoonsolous" whlch points out at least one aspect of the romantio view of myth persisting into the twentleth century. Auguat Wilhelm Sohlegel, we reoell, drew from Flchte and Schelling the foundation of his arguments that poetry and philosophy exprese truths whioh myth 
49.

expresses unconsolougly. The idea of a reoppltulation of mankind's psychic development in that of the individual, as theorized in Jungian depth psyohology, has aroused new interest in the relationship of myth and literature. As in Schlegel's poetics, the argument is again that myth and poetry are trying to express many of the same things. Sohlegel could have made good use of these later theorles of myths as archetypal patterns in pootry. He defined three a gpeots of Naturpoesie: language, rhythm and myth. The first two of these are handed down, transformed and reborn, and so remain a vital part of Kunstpoesie. But myth, in Schlegel's view, 1s merely used, and with the passing of time even 1ts usefulness deoreases. Myths lose their vitallty and cannot be re-enlivened or created anew. Sohlegel would undoubtedly have welcomed a plauglble argument that the third element of his Naturpoesie also Iives on as a formal element in literary art. 
OHAPTER III

POFSIE, GENIUS AND PEANTASIE

This chapter begins a discussion of Poegie in a more purely I1terary sense. The subject of poet1o art 1s, of course, inseparable from the elements of Naturpoesie which we have just considered. So the present chapter marks a shift in perspective rather than a change of subject. First of all, further definitions of the word Poesie will be sought. The results w11l then be clarifled somewhat by examining the mental conditions of art's oreation, namely, human genius and Phantesie. After this, succeding ohapters will discuss the nature of Poegle as finished I1terary products whioh can be experienced and critiolzed and whioh have a place in literary history.

We might expect a simple definition of Poesie to be arrived at etymologically. But polegis, says Schlegel, meana: "schaffende Wirksemkeit der Fantasie" (Berlin, I, 10). He adds that as such it is an element in all the arts. Thus the shortest and most concise definition Schlegel has to offer 1s problematical. As he uses the word Poegle here, it 1s far from denoting a mere collection of verbal artifacts which 1s poetry in the most na1ve sense. Rather, Poegie 1s an activity, part of the rorking of oreative Imagination, and 1t 1 a an activity necesgary to all of the arts. 
51.

In some respects Poesie is perfectly comprehengible and even perceptible. It approaches the conrete through the medium of language. Poesie as an activity and Poesie as specific Ilterary works are tied together by Schlegel"s theorles of language, a subjeot whloh has already concerned us. We recall that Sohlegel developed from Herder the thought that language is the mirror of the mind in the procegs of thought. Purthermore, language not only reflects man's thinking but also the mechanlsm of his thought processes. In the words of the Berlin Lectures, "Die Sprache 1st kein Produkt der Natur, sondern ein Abdruck des menschlichen Gelstes, der darin die Entatehung und Verwandtschaft seiner Vorstellungen, und den ganzen Mechanismus seiner Operation niederlegt" (Berlin, I, 26I). Thus, we recall, language is a revelation of the truths of transcendental philosophy.

Ianguage 1s the medium of Poegle: "Poesle 1st eine bildende Dargtellung der Innern Fimpinindungen und der äußern Gegenstände vermittels der Spraohe" (1798, p.16). But language, and with it Poegle, is involved in all thinking and Poegle is therefore an element in all the arts.

Jeder äußern materlellen Darstellung geht oine Innre in dem Gelste des Kunstlers roran, bey weloher die Sprache immer als Vermittierin des Bewußtseyns eintritt, und folglich kann man sagen, dar jone jederzeit aus oem Schooße der Poesie hervorgeht. (BerIIn, I, 261)

From Schlegel's ramifloations on this theme it is not alear 
52.

Whether or not the poetic-linguistic element in the plastic arts 1s ever aotually expressed in words. The terms of his discussion of I1terary art tend to suggest that it is not.

Some of Sohlegel's most characteriatic atatements about the nature of 11terary art ar1se from the 1dea that in it the creative process is raised to a higher potential since literature's medium of expression is the same as that of the inner consolousness at the birth of all art, namely, language. So Poegle as l1terary art reflectg back on Poesie as language, the mediator of consclousness. On this point Schlegel speaks lyrioally and at length:

Es wird also in der Poesia schon Geblldetes wieder geb1ldet; und die B1ldsamke1t 1hres Organs 1st eben so grinzenlos, als die Fihigkeit des Gelstes zur Rückkehr auf sich selbst durch immer höhere potenzirte Reflexionen. Fe 1st daher nicht zu verwundern, das die Frsoheinung der mensohliohen Natur in der Poesie sich mehr vergeistigen und vericlerren kann als in den thrigen Kunsten, und das sie bis in mystische gehelmniprolle Regionen eine Bahn zu finden reis. Sie hat nicht bloß das körperlich wahrnehmbare Un1vergum tor sich, sonderm alle Kunstbildungen, ganz besonders alles was Diohtung 1st, zleht sie wieder In Ihre Natur, dis daduroh zu einem schönen Oheos wird, aus welchem Ilebe und Hap, oder mit anderm Worten Bagelsterung, das mächt1ge beherrschende Gefthl der Sympathieen und Antipathieen, neue harmonlsohe Schöpfungen aussoheldet und hervorruft. Man hat es höchst befremdlioh und unverstendlioh gefunden, das von Poesie der Poesle gesprochen worden 1st; und dooh 1st es flur den, welcher therhaupt von dem Innern Organismus des geistigen Daseyns einen Begriff hat, sehr elnfach, das dieselbe Thatigkeit, duroh welche zuerst etwas poetisohes zu Stande gebracht wird, sioh auf ihr Resultat zurulokwendet. Ja man kann ohne Ubertrelbung und Paradoxie agen, daß elgentlioh alle Poesle, Poerie der Poesle sey denn sle setzt sohon die Sprache voraus, deren Frfindung doch der poetischen Anlage angehört, die selbst 
53.

ein Immer werdendes, s1ch verwandelndes, nie vollendetes Gedlcht des geseimten Menschengeschlechts 1st. (Borlin, I, 26I-62)

Without mentioning his name, Sohlegel refers here to Friedrich"s A thanaeum fragment where the term "Poesie der Poesle" is used in reference to works which refleot their author's self-consclousness in the process of creation. I Priedrich also calls this combination of poetry and poet10s "Transzendentalpoes18." This term is even more appropriate to August Wilhelm's expanglon of the 1dea of "Poesle der Poeslex" H1s acceptance of a transcendental view of poetry allows him to maintain that all literary art is a "Potenzleming" of the process whereby language, the primordial form of Posaie, first came into existence. In a sense, language 1tself is poetry and the works of poets are accordingly poetry raleed to a higher level, "Poesie der Poegle."

In Sohlegel's statements quoted thus far in th1s chapter lies the germ of the 1deas whloh muat be explored next. We found him using the words Bild and ansahauen and their derivatives. The best approach to those subjects 1s through contrasting Possle and prose, for the latter, in Schlegel's View, is oharateristically language stripped of 1ts B1ldilohke1t and Ansohaullohke1t.

Perhaps the most nalve of all definitions of poetry. is the almple statement that it is the opposite of prose. $1_{\text {Rl Boh, }}$. 53 . 
54.

We find Schlegel using this definition but with subtle qualifications of some importanoo. Ilterary art, Poesie in a broad sense, can, of course, be in prose. This, however, is a subjeot to be discussed along with Schlegel's 1deas of romantio poetry, not the least of whose accomplishments was the paradoxioal one of raiging prose to the level of Poerie.

Our starting point is a passage in the Berlin Irectures where Schlegel a skg,

Woduroh kommt denn nun das Prosalsche in die Sprache? Dadurch das sich der Verstand der Zeiohon bemächt1gt, welche die Finbildungskraft urspringlioh ersohaffen hat. Fa liegt namlich im Fesen der Sprache diese Zreydeutigkeit, das eben das Zelchen was zuerst ein Bild war, sich in elnen Begriff verwandelt, je nechdem die bezelohnete Vorsteliung auf die Finbildungskraft oder auf den Veratand bezogen wird. (Berlin, I, 282)

The 10s8 of lenguage's depletive nature 1s, however, a process which 1s never aompleted. Ianguage, saya Schlegel, oan never become completely unpoetic. Poetic elementis are always there even $1 f$ they may be well hidden. And, he adds, "d1e Rllakehr zur Anschaul1chke1t, Belebthoit und Blldllchkeit muß 1mmer gefunden werden können" (Berlin, I, 282). This rediscovery 1s a charaoteristio aotivity of Poeg1e.

Iangrage 1s in essence poet1o, that 1s, it is vivid, lively and presents concrete images. Prose 1s a deterioration of language which arises from conceptualization and stifles the poetio qualitieg of language by making it sub- 
servient not to imagination but to the goal-directed understanding. All language wag poetlo before this process began and in Poeg1e as art (Fungtpoeg1e) the poet1o in language is rediscovered or even, as he puts it on one ocoasion, oreated anew.

Of the three qualities of Poegie as distingulshed from prose which Sohlegel mentions, it is Blldlichkelt which is the most Important. Th1s quality, in fact, includes the others. Poegle presents concrete 1mages. A number of speculations on this theme are central to an understanding of what is involved in Sohlegel"s 1dea of poetic art. When his discussions of poetxy and poetic language are congidered together, we see that he uses the words B1ld and ansohaulich together with their derivatives so often that the very 1dea of Poesie almost becomes a plastic image. This definition from the 1798 Iectures was oited previously: "Poesie 1st eine bildende Darstellung der Innerm Fmpfindungen und der tupern Gegengtilnde vermittels der Spreche." Taking into account Sohlegel's 1deas on the nature of language, we might rephrase the ending of this statement as "vermittels der bildlioh darstellenden sprache" which 18 to say, "vermittels der Poesie." The purpose of traoing this ofrole 1s to point out that BildIlohke1t as a quality of language 1s inseparable from the same quality in "poems," thet 1s to say, individual instances of Poegie. Poegie dwella hidden in languege and it is Poegie whioh 1a able to bring 1t back into alght. 
56.

Returning for a moment to Schlegel's speoulations on Urgprache, we recall his saying that the earliest language 1s "Im hö chsten Grade trop1sch: und bildiloh, d. h. poet1soh" (1798, p.23). Ianguage originally presented nothing but 1mages, and in 1ta earliest form it did so by means of sounds whioh corresponded to the feelings aroused in man by objects and their qualities. It is not necesgary to disouss here the lingulatic merits of such a theory. The essential point is that Schlegel is saying that Poesie, unlike everyday prosalo language, deals in words which are profoundly appropriate to the things they refer to. This is because they somehow present (derstellen) the objects to our very senses, as it were, by arousing in us feelings similar to those which are aroused in an act of perception.

The following pasage is an example of how intimately connected are Schlegel's somewhat over-philosophic linguistios and his poetios. It is from the same page where the germ of the 1deas set down in the preceding paragraph is presented and is a good example of the rather disconnected revelatory style of the 1798 Lectures. The pasagge is included here mainly for the context of one of the more interesting of Sohlegel's pronouncements on

\section{Poesie:}

Die Zelchen der Sprache haben mit dem Hórbaren eine unmittelbare Ihnlichke1t. Da das sich Bewegende auch meistens hórbar 1st, so geht die Bezelohnung vom Hörbaren aus. We1l aber der Mensch mit der Sprache 
57.

Immerfort darzuatellen strebt, so mup or, was in andere Sinne fïllt, durch ubertragene Ihnliohkeit anderer Sinne bezeichnen.

D18 Frwelterung der Sprache setzt eine ununterbrochene Kette von Verglelohungen voraus; die fritheste Sprache 1st daher in höohsten Grade tropisch und bildilch, d. h. poetisoh. Poesie 1st blldilch anschauender Gedankenausdruck. (1798, pp.22-23)

Pootic language is bildilich and in a statement quoted earlier it was also desoribed as ansohaulioh. These are objective qualities of poetic language and hence of poetry. More subjectively considered, Poegle is bildlioh anschauend.

All this talk of conoreteness, the plasticity of Poesie, leads one to reflect on the last word of the passage fust quoted: Gedankenausdruck. To anyone who has considered the preponderance of abstrations in the expresslon of our thoughts, it would seem that if Poesie is above all b1ldilch, then it 1s severely limited as a means of such expression. Sohlegel denies such limitation and, in fact, maintains just the opposite. Fohoing Sohelling and Novalis, he says that Poegle is the highest speculation. It 1a philosophy cast in plastic images. We have seen that language spans the cleft between the material and the intellectual. It confirms our intuition that body and mind are essentially inseparable. Moreover, in case we lose sight of the fact that Poesle can expreas a whole view of the world, we have only to look baok to the Greeks who expressed the highest philosophical and religious ingights by means of vivid physical 
58.

Images in their mythology. Kungtpoegle can do the same and it does so not, as many naively suppose, by merely glving idea a contrived allegorloal clothing. Rather, Poegie is Immediate to the things of which 1t spoaks, for 1t is itself a way of looking at man and the world. Schlegel says in the Berlin Lectures, "Die Poesie 1st, wenn 1oh so agen darf, Speoulation der Fantegie..." (Berlin, I, 292). The philosophical justification of this statement 1s derived from Schelling. The same conclusion is stated often by Novalis whose view of the 1dentioal alms of poet and philosopher are refleoted in the following pasage. Sohlegel is explaining Arlatotle's rejection of Empedocles as a poet when he says,

Allein auper seinen Vorurtheilen von der Nachahmung rithrt die $\beta$ wohl wenlger von der Strenge her, womlt er die Rechte der Poesle handhaben wollte, als devon, das $1 \mathrm{hm}$ die Idee f̈chter Speculation verlohren gegangen war, und der logisohen Reflexion Platz gemacht hatte. Deswegen konnte er nloht einsehen, wie das Streben der Poesle und Philosophie selner innersten Natur noch elns 1st, so daß jene eine exoterisohe Philosophle, diese eine esotarische Poesle genannt werden kann. (Berlin, II, 291)

In these passages the word "speculation" takes on a good deal of 1ts etymologial meaning of observation. Poesie, through Phantesie, aotually sees the workings of man and the world. The presentations of what Poesie sees are vivid 1mages. We recall the definition alted earlier: "Poesle 1st bildlioh ansohauender Gedankenausdruck." The source of poetry's expresilve power is poet1o language. Philosophioal 1dealism ralses this observation 
59.

above the level of the superflcially obvious. In the second serles of Berlin Lectures Schlegel says,

[Dle thigrigen Klinste] sind mehr oder wenlger durch inre besondern Mittel der Darstellung auf gewlsse Gegenstände beschränkt: der Poesie alleln ist es gegeben, das gesamte Gemulth des Mensohen augzusprechen, sein ganzes äuperes und inneres Daseyn abzuschliderm. (Berlin, II, 6)

We need only recall Schlegel's observation that poetry's medium of expresaion is the same as that whereby we are first able to form consolous 1deas of things in order to understand why it is so apt a means of expression. Poesie is both language and I1terature, both a means of apprehending the world and the product of that apprehending expressed in words. All Poesle 1s Poesle der Poesle, as Sohlegel puts 1t, and 1ts expressive powers achieved through" helghtening by self-reflection are limitless.

Sohlegel says on several occaslons that the limit to what can be oalled Poesie is hard to determine since poetry is latent in all language. Poesie is an element in language no matter how prosa10 a goalilt serves. At the other extreme, however, 1s I1terature, where the elementary form of Poeg1e is concentrated in poetic structures. Our next concern is with the qualities of mind necessary for the conscious production of such struotures.

One of the qualities of mind most often attributed to creators of fine art is genius. The word is part of Schlegel's theoretioal vooabulary. It 1s not, however, used as often as we might expect or as precisely as we might 
60.

hope. The word comes up most often in his arguments with other theorlata and is defined largely by way of pointing out the inadequacies of earlier definitions.

Schlegel's most coherent discussion of genius develops from his critlcim of Kant's Kritik der Urteilgkraft. Here are the quotations he makes of Kant and the starting point of his own argument:
"Das Genle kann nur relchen Stoff zu Produktion der schönen Kunst hergeben, die Verarbeitung des- selben und die Form erfodert ein durch die Schule gebildetes Talent." Ferner: "Der Gesohmack, die Disziplin oder Zucht des Genle's, beschneidet diesem sehr die Flpgel, und macht es geslttet oder gesohliffen." An und flr slch werre des Genle folglioh ungesittet und ungeschliffen. (Berlin, I, 82)

The denial of the conclusion in the last sentence conteins the essence of Schlegel's 1dea of genius. It is not the mere raw product of nature which has to be disclplined by an outslde force. Th1s is not, however, to say that genius 1s not disolplined, rather that disoipline is part of the nature of genius, not something forced on it. Th1s is nowhere brought out more clearly than in the Vlenna Lectures where, in discussing Shakespeare, the whole Sturm und Drang 1dea of wild and extravagant genius 1s attacked:

Die Thëtigkelt des Genles 1st zwar inm eine nathrliche und in gewissem Sinne bewuptlose, wovon also der, welcher sle auglibt, nicht Imer Augenblicklich Rechenschaft wird ablegen können; es 1st aber kelneswege eine solche, woran die denkende Kraft nioht einen grossen Anthe1l hätte. Fben die Sohnelligkelt und S1cherhe1t der Gelateswirikung, die hüchste Klarheit des Verstandes maoht, das das Denken be1'm Dichten nicht als etwas Abgesondertes wahrgenommen 
wird, nicht als Nachdenken exscheint. Jener Begriff von der poet1schen Begelsterung, den manohe Ijrische Diohter in Jmlauf gebracht haben, alo weren sie auper sich, und ertheliten wie die Pythia, von einer fremden Gottheit ergriffen, ihnen gelbst unverständIlche Orakeleprltche: Jener Begriff (selbat nur eine lyrische Frdichtung) past an allerwenigsten auf die dramat1sche Oomposition, eine der besonnensten Hervorbringungen des menschlichen Gelotes. (SW, VI, 183)

Genlus seems to be a quality of mind and properly onoggh has both 1ts conscious and unconscious sides which, moreover, Schlegel sees as essentially inseparable. At times, however, he 1s willing to separate the two for the purpose of examination. In a number of passages, for example, he stresses the unoonsclous working of genius. Ferly in the Berlin Iectures, in spoaking of the diffioultieg faolng art history, he remarks, "We1l das Genie zum The1l bewaptlos handelt, so kớnnen selbst die ausdrucklichsten Auperungen vom Urheber eines Werkes Uber die Absicht und Bedeutung derselben irre lelten" (Berlin, I, 20). Farlier he countered the argument that genius is a mere freak of nature by attributing it to all of mankind as a ma 8s:

Eben dieser Genius 1st es auch, der das Poet1sche im Ieben hervorbringt, was sich nicht selbst im Kunstwerke conzentrirt, aber auf den Oharakter von Kunstwerken Elnflus hat, von der rohesten Mythologie an b1s zur gebildetaten Sitte; alle die mannichfaltigen Phänomene, wo die Mengchheit in Masse zu dichten scheint. (BerIin, I, 19)

Thus the 1dea of genius is expended to fit in with Schlegel": 1deallet view of history which we will examine 
62.

later. In his final refutation of Kant's suggestion that genius must be tamed by taste, Schlegel did not, however, have to lean very heavily on his new philosophical mentors. His argument is that creative genius involves a harmony of man's faculties similar to that which Kant himself maintained was present in aesthetic judgment. This is Schlegel's most elaborate attempt at defining genius, but it is short onough to be quoted in full:

V1elmehr so untrennbar wie in einem ächten Kunstwerke das, was man das poetisohe, und was man das kilnstliche nennen kann, sind, so untrennbar 1at auch der wahre Gesohmack vom wahren Genle. Dieses 1st eben die Innigste Verelnigung der bewaktlosen und der selbstbewasten Thätigkeit im mensohlichen Ge1ste, des Instinktes und der Absicht, der Freyhe1t und der Nothwendigke1t. Deswegen, weil in $1 \mathrm{hm}$ die urgpritingliche Entzweyung sich aufhebt, worin der Mensch als ein endliches. Wesen sich endlos befangen sleht, erscheint es uns auch als etwa sbermensohllohes, als eine göttliohe Kraft, und seine Mittheilungen als wahre Offenbarungen. Derum 18t auch zum Genie große

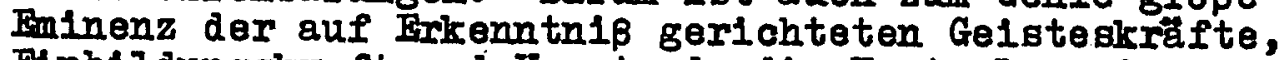
Finb1ldungakraft und Verstand, die Kant als seine Bestand theile anglebt, nioht hinreiohend, sonderm es umfast den ganzen innern Menschen, und kann in nlohts geringerem bestehen, als in der Fnergie und innigsten Fintrecht dessen was sowohl in der Sinnlichkeit als in der Geistigkeit dea Menciohen das selbstständ1ge und unbeschrinkte Vermögen 1st, also der Pantasie (die man in diesem Sinne noch ron der Finb1ldungakraft untersoheiden kann) und der Vermunft. (BerIin, I, 83-84)

In disoussing genius at this point the purpose has been to introduce Soblegel's views on the origin of a work of art. What we have learned so far is first, that art is the product of genius and, secondly, thet the working of geniug is both consclous and unoonsolous, rational and imaginative. The first of each of these two sets of terms require 
63.

no elaborate explanation and, in fact, Schlegel is satisfled merely to assert and show by example (Shakespeare, among others) that there is a conscious and rational side to the working of genius. Ita unoonsclaus and Imaginative sides are, however, more problematical. Our starting point in examining Schlegel'g views here is the word Phantasie appearing in the long passage just quoted.

In discussing mythology Sohlegel makes his most revealing statement about Phantagie. The question he facer is that of the nature of myth"s claim to truth:

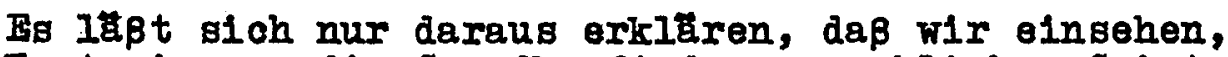
Fantasie sey die Grundkraft des mengchlichen Gelstes. - - Der urspringlichote Akt der Fantagle 1st derJenlge, woduroh ungre elgne Bxistenz und die ganze Aupenwelt fur uns Realitat gewinnt. Dap diese ein Produkt unsrer elgnen Thätigkeit sey, kann jedoch nur durch Speculation dargethan werden, nie ins Bewuptseyn fallon. Das entgegengesetzte Fxtrem ist die kinstlerische Wirksamkeit der Fantasie, die selbstbewupt 1 st und mit Absioht geleitet wird. Diese 18t in Ansehung ihrer Produkte rein 1deell, d. h. sie macht fur sie keine Anspriche auf Wirklichkelt, und bederf deren nioht. (Berlin, I, 329)

These statements and their Plohtean besis were considered earlier when we sew that the activity of Phantagie which produces myth I1es between the extremes and gives to myth an 1deal real1ty. Here we are concerned with what schlegel 1s saying about Phantagle.

Phantegie 18, then, the mental faculty both of man's perception of objective reality and of his oreation of an artistic reality. For the most part Schlegel leaves the first aspect of Phantasie to the philosophers, but on 
64.

1ts artistic activity he has more to say. In the Vienna Lectures we read, "In aller Kunst und Poesie, vornehmlioh aber in der romantischen, macht die Phantasie als eine unabhängige Seelenkraft, die sich nach elgnen Gesetzen reglert, ihre Angprilche geltend" (SW, VI, 185-86). But while Phantasie is independent and follows 1ts own laws, Its aotivity is sometimes considered by Sohlegel to be analogous to that of other mental faculties, of understanding, for example. Here is a further statement on the theme from Schelling and Novalis that poetry and philosophy strive toward similar goals: "Die Poesle 1st, wenn Ich so sagen darf, Speculation der Fantasie; und wie die philosophische Speculation die Fählgkeit zu abstrahiren dem Verstande zumuthet, so die poet1sohe der Fantasie" (Berlin, I, 292). This correspondence of art and philosophy in the idea of speoulation points to a further qualification of the independence of Phantasie. While it is free and follows only 1ts own laws, we must nevertheless recall that it is.a faculty of the mind and as such is a means of apprehending reality, with which it does not lose contact. Sohlegel tells us,

Wenn man . . das Wort Natur . . bis zum Inbegriff aller Dinge erweltert, so leuchtet freylich oin, das die Kunst aus dem Geblete der Natur Ihre Gegengtände hernehmen muß, denn es glebt alsdann eben nichts anders. Die Pantasie kann in 1hren kihnen Fligen zwar tubernatirlioh aber niemals aupernaturlich werden: die Flemente 1 hrer Schöpfungen, wie sle auch durch inre wunderbare Thätigke it verwandelt seyn mögen, milssen immer aus einer vorhandnen Wirklichkeit entlehnt seym. (Berlin, I, 100) 
Imagination borrows the objects of its activity from nature, yet that activity can somehow be ubernaturlich and is spoken of in terms of flights and transformations.

Phantasie 1s necessary for the production of art. When It weakens, art declines and when it 1s absent, there is no art. Many examples could be cited but two w1ll suffice. Speaking of poetic images getting out of hand, Schlegel says,

Nur auf eine solche Verschwendung von Bildern, welcher kein wahrer Schwung der Fantagie zum Grunde llegt, die also ein blok erborgter therladener Schmuak 1st, paßt die Benennung des Schwulstes, oder des Bombastes, wenn die Fantasie sich aus den heitern Regionen schöner Anschaullohkeit in das Verworrene und Sinnlose verliert. (Berlin, $I, 292$ )

This passage also contains an implied denial of any suggestion that Phantagie deals in mere luxuriant or narcisslstic phantasies. The derogatory connotations of the Finglish word "phantasy" point to just those qualities of mind and of false art which Schlegel denies belonging to Phantagie and 1ts productions. Furthermore, just as Phantegie is stifled by mere luxuriance for 1ts own sake, so too it is stifled by bringing it down to earth. So, in the Vienne Lectures, Sohlegel justifies the artiatic worth of comedy by saying,

Die alte Komödie lat aber ein eben so unabhängige und urgprïgliohe Dichtart als die Tragödie, gle steht auf derselben Hohe mit $1 \mathrm{hr}$, des heipt, sie geht eben so weit tuber eine bedingte Wirklichkeit in das Geblet der fre1 schaffenden Phantasie hinaus. (SW, $\mathrm{V}, 181$ )

Phantagle hovers somewhere between the fantastic, in the 
66.

bad sense, and "bedingte Wirklichke1t." Just where this 1s we w1ll see when we take a close look at the subject matter and mode of existence of poetry.

Poesie and poetisch are terms of very broad application in Schlegel's poetics. It should be noted here that wherever Poegle 1s part of life, Phantasie is there too. Mythology is an example, and so is religion in general (Berlin, I, 350-51). The 1797 essay "Über Shakespeares Romeo und Julia" dwells on the romantic theme "Ifebe 1st die Poesle des Lebens." The context of this statement concerns us here:

Allein die Bewunderung, die Vergötterung des gellebten Wesens kann nicht bildlos sprechen; sie muß sich zu den kilhnsten Vergle1chungen auf schwingen. Mit dem Zauberschlage, der das Eine, was 1 hr vorsohwebt, aussondert und uber die ganze thrige Welt erhebt, hat sle den Masstab des Wirklichen verloren, und kann bis an die Gränze der Dinge schwärmen, so weit die Fliggel der Phantasie sie nur tragen wollen, ohne sich einer Ver1rrung bewußt $\mathrm{zu}$ werden. Ilebe 1st die Poesle des Lebens: Wle solite sle uber Ihren Gegenstand nicht diohten? (SW, VII, 94)

And so 1t is only to be expected that Romeo and Juliet speak in poetry, a good example of Übernathrlichke1t without Aupernatürlichke1t.

Th1s whole discursion of genius and Phantasie has been handicapped by the lack of precise definitions. Rather Schlegel has defined by noting some of the spheres and modes of their activity. The subject is not exhausted here. Phantagie will be considered again later in conneotion with the experience of Poesie. But now 
the subject at hand is an important a spect of the nature of finlshed works of literary art. 
OHAPTER IV

THE POFIO WORID

Numerous statements by Schlegel elaborate the theme that Poegie and, in fact, all art is fiction. It is fiction in the sense that it is something fashioned by man rather than something merely discoverable in the real world. Art is also fiction in the sense that it is not Iiterally true. Art, speolfioally Poesie, is 1ts own world, obeys 1ts own laws, even sets up 1ts own standards of truth. The relationshlp of the poetic world to the real world may be such that we will use the word "true" to describe what 1 t communicates to us, but th1s 1s truth expressed in the form of a flotion. For the moment it is this flction which must concern us.

In discussing mythology Schlegel makes the distinct1on between myth, which at one time claimed to be I1teraliy true, and the products of "die kinstlerische Wirksamke1t der Fantasie." He adds, "Diese ist in Ansehung 1hrer Produkte rein 1deell, d. h. sle macht filr sie keine Anspritche auf Wirklichkelt, und bedarf deren nicht" (Berlin, I, 329). Iater, in his leotures on the drema, Schlegel carries this thought further by stating that it is a fault in a play if it deceives us into thinking that 1ts action is real rather than fictional. The statement just quoted from the Berlin Iectures was more 
69.

general and included all the arts. In a sense they are all flotions rather than realities.

But perhaps a better expression than "fiction" is "poet1c reality." Art is certainly something real, but Ita reality is of a different order than that of the material world. An appropriate point at which to begin defining this difference 1s Schlegel's 1dea of mimesis. Schlegel lays special stress on the fact that whatever passes from reality into art is transformed by man in the process. In a quarrel with the followers of Aristotie he says of art,

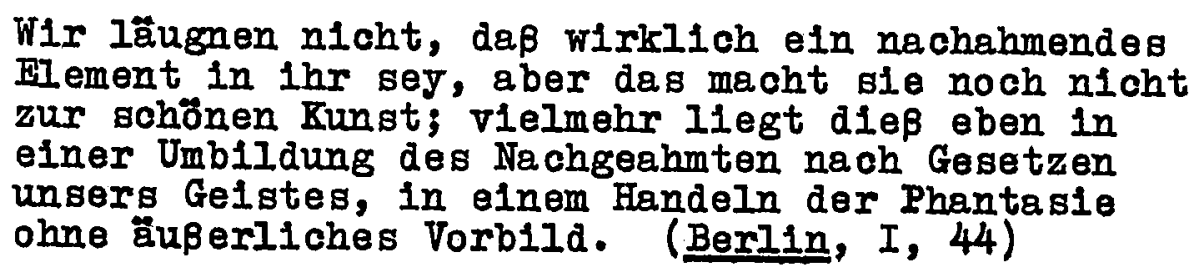
This "Umbildung . - In einem Handeln der Phantasie" 19, as we have seen, first of all a poetic-linguistic process of Imagining, that is, forming an image of, the work of art. In the case of literary art, this transformation assumes a remarkable character since language, the mediator of consciousness, is also the form of the further transformation into the work of art. Whence, we recall, the formula "Poesie der Poesie."

The foregoing has put the problem of art as fiction In the terms of art's creation, its ooming into being. When, however, Schlegel looks beyond the creative act to the created product he maintaing this point of viow and 
sees Poesie as something separate and finely distinguished from reality. An often used Image is that of a world, one which follows different laws then those of the real world. In the course of a lengthy argument against overstrict dootrines of verisimilitude Schlegel says, "Fe kommt nur darauf an, daß ein Dichtex uns durch den Zauber der Darstellung in eine fremde Welt zu versetzen weik, so kann er alsdann in ihr nach seinen elgnen Gesetzen schalten" (BerIIn, I, 98). We are drawn into a foreign world by Poesie and are not to be deceived into believing that it is the real world. In speaking of the poetic element in all the arts Schlegel says,

Dasfenige in den Darsteliungen der tbrigen Ktinste, was ung uber die gewôhnliche Wiriklichke1t in eine Welt der Fantasie erhebt, nennt man das Poetische in Ihnen; Poesie bezelchnet also in diesem Sinne taberhaupt die kïnstlerische Erfindung, den wunderbaren Akt, wodurch dieselbe die Natur berelchert; wie der Name aussagt, eine wahre Schöpfung und Hervorbringung. (Berlin, I, 26I)

Here the two aspects of the poetic flction are brought together: It is something created by man and 1t is a world of 1ts own into which the audience is drawn. It was at this point that Schlegel went on to say that the birth of art ocours in two stages, the first in the mind of the artist and the second 1ts rendering in perceptible form. The peouliarity of Poesie is that language is the medium of both.

If art is nature transformed through man, it would seem that the form it takes depends entirely on the 
1ndividual. Schlegel counters this 1dea with an argument in Kantian form. It 1s true that we are individuals and our individual personalities determine our view of the world. But we are also men and share with humanity certain common features, among them the sense of beauty and a sense for the appropriateness of certain forms of expression. The quality of poor art whioh reflects the purely individual determination of 1ts content is manner. How does one rise above mannerism? Schlegel's angwer is th1s:

So wle die Sittlichkelt von uns fodert, unsern Fgo1smus aus Gehorsam gegen ein höheres Gesetz zu bezähmen, oo wird die kinstlerische Tugend ... darin bestehen, daß sich der Kungtler, den Gesetzen des Schönen und der Darstellung zu lieb, selner

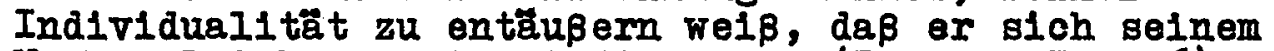
Werke glelchsam unterwirft.. (Berlin, I, 106)

The influence of Kant and Sohilier is evident in this whole disoussion of willful submission to a higher law. Thus Sohlegel distingulshes manner and stjle, and defines the latter as "elne Verwendlung der Individuelien unverme1dlichen Beschränktheit in freyw1lilge Beschränkung nech einem Kunstprinzip" (Berlin, I, 107). The Kunstprinzip which rules art is not flxed but rather varies. Art, says Schlegel, is an infinite whole, an idea, and no one person ever grasps it completely. Style 1s governed by th1s 1dea of art, yet it expresses an individual's conception of 1t. So there can be many atjlea. They are the expressions not only of individuals but also of the various kinds of art, the varlous genres within these and 
of the various stages in the historical development of an art.

The application of these thoughts on manner and style to the idea of art as fiction is as follows:

Zw1schen der Kunst und der Natur steht also nothwendig etwa mitten inne, พละ sie aus einander hält. Dieses heipt Manier, wenn os ein gefärbtes oder trubes Kedium ist, welches auf alle dargestellten Gegengtände elnen falschen Schein wirft; Styl, wenn es den Rechten von Beyden, der Kunst und der Natur nicht zu nahe tritt, welches nicht anders möglich 1st, als durch die dem Werke selbst gleichsam eingeprägte Frkiärung, es gey nicht Natur, und wolle sich nicht daftr ausgeben. (Berlin, I, 107)

Style is thus one of the means whereby it is made clear that what is before us is not nature but rather art. There are other means which establish this separation. Schlegel notea the role of rhythm in differentiating the real world and the poetic world:

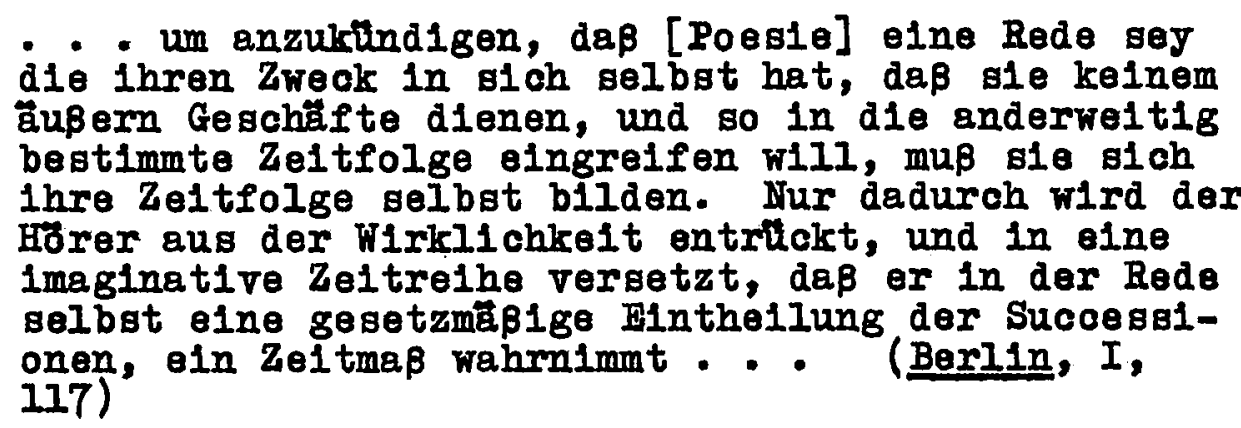

Poegle 1s separated from the real world in having its own time. This is true both of 1ts language and 1ts aotion. The obviaus application of this to the traditional idea of unity of time in drama will be congldered later. Oomparing the epithet and the sim1le, Sohlegel says, Die Verglelchung 1st elne nooh stärkere Anfoderung 
an die Fantasie als das Beywort, slch die Seche sinnlich vorzustelien, und durch Zusemmenstellung mit dem weiter entlegmen gewinnt des Dargestellte an Grobe und Furde, und wird aus der Sphäre der gemeinen Wirklichkelt herausgehoben, wo die Anschauung ihrer Alltäglichke1t wegen keinen Werth mehr fur uns hat . . (Berlin, I, 290)

Even in the case of the most obvious borrowing from objective reality, the senguous image, the object 1s drawn up into another world.

Thus far in this chapter we have seen Schlegel laying great atress on the separation of Poesie and reality. Poesie forma a world of 1tg orm, separate from the real world and above 1t. Presently we must examine the relationship between the two worlds, which involves the whole question of meaning in I1terature. But firgt there remains to be disoussed fingl aspect of Poesie as distingulshed from the rest of the world, namely, poetic form. Here Schlegel eventually shifts his metaphors, for Poesie 1s spoken of not as a world but as an organism, a unified whole whose outer form reflects its essential nature. Schlegel began, however, with a less complex view of form, and this must be examined first.

A number of statements suggest that at times sohlegel considered form something which could be dealt with apart from matter. The "Briefe lber Poesie, Sylbenmas und Sprache" argue that at the very birth of art sound and words had to be articulated. Before there could be Poegle and mus10 there had to be a law of outer form, namely, 
74.

rhythm (SW, VI, 122). Rhythm can, of course, still be part of organic form. It should be determined by the nature of the work 1tself. In an Athanaeum fragment of 1798 sohlegel in effect criticlies outer form which is not innerly determined when he speaks of "geigtloge Regelmäß1gke1t.. - "Vernthftig aber dumm"" (SW, VIII, 4). Leter Schlegel's 1dea of form becomes so involved in the organlc concept that matter and form are indistingul shable. Here in his early work he has distinguished a formal element which definftely can be considered apart from a speciflc content. In the Jena Ieoturea Schlegel again speaks of rhythm in terms of form:

Beim Wohlklange 1st zu untersoheiden die Besohaffenheit der Laute und ihre Bewegung: Fuphonle und Furhythmie; in beiden findet etwas Sinnliches, Wohlgefalliges, Angenehmes und etwas elgentiomlich Schönes und Bedeutendes statt. Furhythmie bestimmt mehr die Verhältn1sse der Bewegung, die Form; die Fuphonie mehr die Materle, die Annehmliohka1t der worter. (1798, p.44)

However hazy it may be, a diatinction of matter and form 1s atill consldered possible. The connection of form with relationships of morements is noteworthy, for later we find the 1dea of form so bound up in the notion of an organic whole that all thought of movement 1s set aside. Further examples of Sohlegel's speaking of form as something which can be discussed apart from content oan be clted. In the Jena Lectures Sohlegel speaks of "Pormen der Finkleldung" of the ode (1798, p.141). In comedy not only what is presented but also the form of 
presentation must te scherzhaft (1798, p.190). Part of the effect of comedy is a contrast of matter and form (1798, p.191). In discussing satire he goes so far as to suggest that "Nur mup an den Satiren, wenn sie poetisch sein sollen, die Form einen unbedingten Wert haben" (1798, p.205). Th1s is what raises them above being mere means to some destructive end:

Be1 den Nouern hat man den Namen Satire auf jede ernathafte oder spottende Verfolgung der Ohristen oder Torhe1ten ausgedehnt, be1 der man doch erst die Form und Bahandlung unterschelden mus, ob ale zur Poesie gehören soli, oder nleht. (1798, pp. 203-204)

Iater Schlegel makes a similar statement about architecture. Whether 1t is art or not depends on whether 1ts form is governed by aesthetic or utilitarian prinolples. If the former, then it is art even though it does serve a purpose. In another early work Schlegel makes rather extens1ve use of a non-organio view of form. In his "Betrachtungen Qber Metrik" he writes,

Jeberhaupt beruht die Form 1mmer auf Verhëltn1agen. Der ăußere Sinn empfängt einzelne Findricke-- nur der Reflexion des Inneren Sinnes ist es gegeben, Verglelchungen unter 1hnen anzugtellen, und mehrere als ein Ganzes zu betrachten. In der Sprache also, sofern sie als etwas Hörbares betrachtet wird, machen die Bestandthelle der Silben die Materle aus, ihre prosodisohen und rhythmischen Verhëltnisse die Form. (SW, VII, 158)

Soon he adds to this, saying,

Die Bestandthelle der Silben, sagte 1ch oben, sind die Materie der Sprache, in so ferm sle etwas Hörbares 1st. Aliein in elner andern Hinsioht 
sind diese Bestand theile auch Form-- nämlich in so fern s1e etwas bedeuten. Denn hier 1st ein Verhâltniß zw1schen Bedeutung und Laut; der innre Sinn vergnugt sich daran, Analogien zu suchen und zu finden. (SH, VII, 16I)

Form, he says, consists in relationships which, however, are not perceptible by the senses but by an Inner sense which 1s able to see wholes and compare parts. Here and in his other early works Schlegel considers rhythm to be a formal element. He even goes so far as to consider gyllables a formal element 1sofar as they make us aware of a relationship, nemely, that of the sounds to their meanings. Again the form is perceptible only to the inner sense.

There is a missing middle step in Schlegel's speculations on form. Although 1t is never explioltly stated, at some point he muat have considered the fact that if form consists of relationships then the total form of a work of art must consigt in the totality of all 1ts relationships, Inner and outer. Brentually he speaks of form only as the form of whole works.

It is in the course of his discussion of figures of speech that Sohlegel warns against seeing the essence of poetry in 1ts parts. He states the fact,

daß man niemals dahin gelangen wird ein schönes Ganze aus vermeyntlich schönen Flementen zusammen zu stlkcken, sondern das Ganze muß erst absolut gesetzt, und daraus des Finzelne entwickelt werden. (Berlin, I, 291)

Farlier Sohlegel had expressed the 1dea that Poogie is a 
77 .

unifled whole but noted the difficulties in apprehending it as ouch:

Man wird finden, daß die meisten Mensohen an einem Kunstwerke nur das elnzelne loben oder tadeln von dieser oder jener Schönheit daran, wie man ea zu nennen pflegt, aind sie ergriffen; das Genze ala solches aber 1st fitr sie elgentlich nicht vorhanden, besonders wenn es von bedeutendem Umfange 1 st. (Berlin, I, 25)

He goes on to contrast atomistic w1th organio critiolsm, saying that only the latter really grasps the true nature of the work. Presently we will find Schlegel suggesting that form is an attribute of the whole work. Problems arise, however, from a fact that he himself has noted, that the material of Poesie 1a presented successively in time. The difficulties this poses for the inept critic, whom Schlegel has just characterized, unfortunately are difficulties which he himself never quite overcomes in his theorizing on form.

The most emphatic pronouncement on the subject of form comes in the Vienna Lectures. Works of Iiterary art must obey rules whioh arise from the1r own nature:

Formlos zu sein darf also don Werken des Genlus auf kelne Welse gestattet werden, allein es hat damit auah keine Gefahr. Om dem Vorwurfe der Formlo algkeit zu begegnen, verständige man sich nur uber den Begriff der Form, der von den Melsten, namentlioh von jenen Kunstriahterm, wolche vor allem auf steife Regelmëßlgkeit dringen, nur mechanlsoh, und nicht, wle er solite, organisch gefaßt wird. Mechanisch: lot die Form, wenn sie durch aupre Finwirlung 1rgend einem Stoffe blok als zufallige Zuthat, ohne Bezlehung auf dessen Beschaffenheit erthe1lt wird, wie man z. B. einer weichen Masse elne bellebige Gestalt glebt, demit sie solche nach der Frhërtung beibehalte. Die organische Form hingegen 1st eingeboren, 
sie bildet von innen heraus, und erreloht ihre Bestimmtheit zugleioh mit der vollstädigen Finwickelung des Ke1mes. Solohe Formen entdeoken wir In der Natur tuberall, wo fich lebendige Krafte regen, von der Krystalilation der Salze und Mineralien an bis zur Pflanze und Blume und von dieser b1s zur menschlichen Gesichtsbildung hinauf. Auch in der schönen Kunst, Wie im Geblete der Natur, der höohsten Klnstlerin, alnd alle ächten Formen organ1sch, d. h. durch den Gehalt des Kunstwerkes bestimmt. Mit Finem Worte, die Form ist nichts anders, als eln bedeutsemes Aeupres, die sprechende, durch keine störenden Zufêlligkeiten entstelite Physiognomle jedes Dinges, die von dessen yerborgnem Wesen ein wahrheftes Zeugnis ablegt. (SW, VI, $157-58$ )

We oan see traces of Schelling ${ }^{*}$ s influence in this equation of natural form and artiatic form. Sohlegel's purpose is a practical one. He wants to provide a basis for critical judgment of poetic form. He seems to assume, however, that form oan really be discussed only in bad poetry where It 1 s something whioh can be distinguished from content. In the best art the distinction vanishes. Iiterary form 1s determined by the content. It 1s essentlal to the work in the same way that the form of an organism is essential to 1ts nature.

In oriticizing people who imagine that poems are written by arafting them in prose and then casting them into verse, Sohlegel says,

Solche Menschen haben freylich kelnen Begriff, wie die Form vielmehr Werkzeug, Organ fur den Dichter 1st, und gleich bey der ersten Frpfëngnis olnes Gedichts, Gehalt und Form wie Seele und Leib unzertrennlioh 1st. (Berlin. III, 209)

It 1 s this and similar stetements which occasion Wellek's comment that if content and form are indistinguishable 
then for praotical purposes the terms are rather useless. ${ }^{1}$ He goes on to show that in practice Schlegel was forced to make the distinotion.

The problems in Schlegel's view of form arise from the comparative 1solation in his writings of the various general statements about the nature of fictionel strudtures. The important 1ders have already been disoussed: Poeste is an art displayed in suocessive moments in time; a poem (that is, a literary work) is a world in itself, a flotional world obeying Its own laws; a poem is a unified whole: nothing can be added, taken away or properly considered in 1solation; a poem is organic in form in the sense just congldered.

On several occesions Sohlegel uses the adjective "organic" without speaking specifically of form. In the Jena Leotures, for example, the subject 1s the unity of tragedy:

Jene Finhelt aber 1st das Wesen, ist organisoh, und das Ganze 1st wle aus einem einzigen Kein gewachseñ. Die tragisohe Finheit 1st das Hö chate in der Poesie; sle macht Ansprilohe auf unbedingte Totalitat, fir die Vernunft und fir die Finbildung, insofern sioh alles schôn rundet. (1798, p.169)

We note that Vemunft and Finbildung seem to be involved in the perception of tragedy as an organic, unified whole. In the Berlin Leotures Sohlegel attacks the critics who look only at the various parts of works:

Man rônnte dieß die atomistlsohe Kritik nennen . . , Indem sie ein Kunstwerk wie eine Mosaik, wie eine milhsame Zusammenfligung todter Parikelohen, betrachtet;

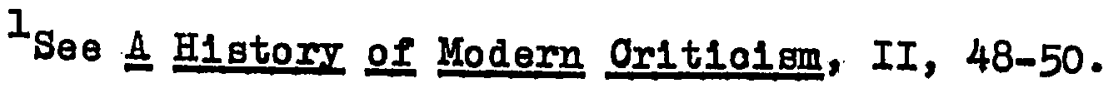


80.

da dooh fedes, welohes den Namen verdient, organlschei* Natur 1st, worin das Finzelne nur vermittelat des Ganzen existirt. (Berlin, I, 25)

This atatement completes the discussion mentioned above where Sohlegel deals with the diffloulty of seeing a successive art work as a unified whole. Wherever this organic metaphor 1s used there is the impliation that the organiom is perceptible only to the most sensible reader, that is, to the right kind of oritio who is able to see the whole work simultaneously.

Sohlegel has sald that Poesie is a successive art, that is, one which is presented in successive moments in time. Yet 1t seems that only the elements of content appear successively since form belongs to the whole which is grasped only by the exceptional reader and then only after the entire presentation is complete. He 1nsists, moreover, that we must see the work as a whole, namely, at a time when all the content except that immediately before us is a memory.

The central diffioulty in uaing the organio metaphor to describe form faces us here. In the Vlenne Ieotures Schlegel spoke of physlognomy, of signifloant exterior, but he falled to state there that, while the exterior of organic forms can be gragped in a single act of perception, that of Poegie Involves many such acts which must somehow be synthesized before one an percelve the form of the whole. It is as if we could see a painting only a square 
Inch at a time, while the whole oould be reconstructed only mentally. In a sense it is even more complicated then this since if we ask "How do the pleces fit together?" the answer is not simply "slde by side" but rather "interlocking, overlapping, mutugily reflecting," and so on. If Schlegel will see poems as wholes, it is not surprlsing that form becomes indistingulshable from content. By the time the whole is seen, all content elements are no longer sensibly present but are memories organized not in a succession in time but rather simultaneously as form. In the discussion of Kant in the Berlin Iectures, Schlegel reaches an extreme formulation in attempting to define das Ideal. Schlegel takes the position that it conslats in the perfect combination of man's animal and rational natures. The implioation for art is this:

So kann man auch ein Gedicht oder sonst ein Kunstwerk mit Recht 1dealisoh nennen, wenn sioh in ihm Stoff und Form, Buchstabe und Geist bis zur vôlligen Ununtersoheldbarke1t gegenseltig durchdrungen haben. (Berlin, I, 79-80)

Here too the disoussion turns to physlognomy, how structure 1s expressive and expression in turn determines structure. As we have seen, it takes only the two further dicta, that poems must be seen whole and that their form 1s organio, to make the 1dea of form a useless abstraction. It is as if an anatomist were allowed to speak of no form smaller than that of the whole body.

But we have seen that Sohlegel himself has spoken 
82.

of form without pressing the organic aspect. He has disoussed it in terms of relationships and of movement. He has also distingulshed at least one formal element in the articulation of the material whloh goes into a poem, namely, rhythm. Schlegel's most dogmat1o statements on form maintain that it is organic and belongs to the art work as a whole. There are, however, evidences of organization in smaller parts of the work. Occasionally he speaks of the latter in terms of form but never reconolles the term used in this sense with his more resolute definitions. 


\section{OHAPIRR V}

ARI AND NATURE

The autonomy of Poegle, in Schlegel's view, is a real one, for poetry accomplishes its goals in 1ts own weys without restrictions from the outgide. Tet Schlegel is far from holding that art exists only for its own sake. Art is related to the whole of man's experience because it says something about man and the world. Meaning, howerer, 1a paradoxiosly not something which ocours either by accident of by contrivance. Meaning arises simultaneously with the symbols whereby it is expresged. A discussion of how and why this is true involves Sohlegel's whole view of the world, of Poegle and of the relationghip between the two.

We saw earlier that Sohlegel's 1dea of imitation was one in which nature is trensformed by man in the process of 1ta benoming art. There is a mimetic element in art, but it is far from being a mere copying of something in the real world. With this 1dea of transformation of nature in art Schlegel assoclates another sense of the word Nachahmung. In the esaay "Etwa tuber William Shakespeare bel Gelegenheit Wilhelm Meisters" he has occasion to speak of the evils of obscurity and confusion in bad art. He says,

Hingegen 1st Klarhe1t eben [so] sehr wie Fulle und Kraft ein unterscheidendes Merkmal des Genius, und folglioh kann in seinen Sohöpfungen nicht wohl eine 
84.

andre Art von Dunkelheit stattfinden, als die Unergritidlichkelt der schaffenden Natur, deren Fbenb1ld or im Kleinen 1st. (SW, VII, 30)

This thought in the essay of 1796 is later elaborated in the Berlin Lectures. There Sohlegel gives full credit to Karl Philfpp Moritz for the 1dea that art 1s modelled on nature in 1to striving for the infinite and for inner perfection. Art is not fust an imitation of physical nature but of nature's creativity, Schlegel concludes. In developing this point he draws philosophical support from many sources. He eohoes the Neo-Platonlsts in maintaining that every atom of the universe reflects the whole un1verge. But only in man is this reflection self-conscious. So it is in man himself that the model for nature's oreativity is found. Nature is organic development and as a self-consclous organism we alone are in a position to realize that fact. Schlegel follows Schelling in maintaining that nature is intelligence in the process of becoming. Only when we consider nature as intelligence can we speak of art as an imitation of nature:

Wird nun Natur in dleser whirdigsten Bedeutung genommen, nicht als elne Masge von Produkten, sondern als das Producirende selbst, und der Ausdruck Nachahmung ebenfalls in dem edleren Sinne, wo es nloht helit, die Außerlichkeiten eines Mensohen nachäffen, sondern sich die Maximen seines Handelns zu elgen machen, so Lat nichts mehr gegen den Grundsatz einzuwenden, nooh zu ihm hinzuzuftgen: die Kunat soll die Natur nachahmen. (Berlin, I, 102)

Art, then, 1mitates creative nature, nature in the process of becoming.

The thought that every part of nature mirrors every 
85.

other part is repeated often by Sohlegel, a it is by

Frledrioh Sohlegel and Novalis. August Wilhelm's argument that this is so is also related to his theories of language :

Die gegenseltige Verkettung aller Dinge durch ein ununterbroohnes Symbolisiren, worauf die erste Blldung der Sprache aich grindet, soll ja in der Wiederschöpfung der Sprache, der Poesie, hergestellt werden; und sle ist nicht ein bloker Nothbehelf unsers nooh kindischen Geistes, sle wêre seine höchste Anschauung, wenn er je vollständig zu 1hr gelangen könnte. Denn jedes Ding stellt zuvôrderst lich selbat dar, d. h. es offenbart sein Innres durch sein \#upres, sein Wesen duroh die Frscheinung (e日 1st also Symbol für sioh selbst); demnä ohst das, womit es in näheren Verhältnissen steht und Finwirkungen devon erfährt; endlich ist es ein Splegel des Untversums. In Jenen gchrankenlosen Ubertragungen des poetischen Styls liegt also, der hañung und Anfoderung nach, die große Wahrhelt daß eins alles und alles eins 1st. Die Wirklichkelt liegt zwischen ihr und uns, und zieht uns unaufhôrlioh davon ab; die Pantasie räumt dlese stôrende Medium hinweg und versenkt ung in das Universum, indem gie es als ein Zauberreich ewiger Verwandiungen, worin nichts 1solirt besteht, sonderm alles aus allem durch die wunderbarste Sohöpfung wird, In uns sloh bewegen Iäßt. (Berlin, I, 93)

We see that art is like nature not just in 1ts activity but also in 1ts meaningfulness. Indeed art is a revelation of the fact that nature does have meaning. The difference between nature and art is again seen to lie in self-conso1ougness:

Der Mensch 1st . - das erste uns bekannte Wesen, das nicht blos fir eine fremde Intelligenz Splegel des Universums wëre, sondern we1l selne Thätigkeit in sioh zuritckgeht, es auch fitr sich selbist seyn kann. Die Klarheit nun, die Fnergie, die Fllie, die Allseit1gke1t wom1t sich das Unlversum in einem menschlichen Gelste absplegelt, und womit sloh wlederum diese日 Absplegeln in Ihm eplegelt, bestimmt den Grad seiner Kunstlerischen Genialitet, und setzt ihn in 
86.

den stand eine Welt in der Welt zu bilden. (Berlin, I, 103)

Here Sohlegel suggests more strongly that art is not Just an analogue of creative nature, but actually is itself a mirror of the world. Art 1s a product of man's own self-conscious reflection of the universe.

Schlegel later carries this argument a step further by seying that nature creates symbolically (sinnb1ldl1oh). "Dio Natur schafft durchaus sinnbildlich, sie offenbart Immer das Innere durch das Aeupere..." (SW, XII, 346). Art consists in imitating nature, here in its symbolizing aspect. An example of where such thoughts can lead is found in the second serles of the Berlin Iectures where the matter being discussed is descriptive poetry: "Das elnzige Mittel, das schildernde Gedioht in elne höhere Sphäre.zu heben, und es wahrhaft zu poetisiren ble1bt wohl die symbolische und mystische Ansicht der Natur" (BerIIn, II, 315). He goes on to say that a more profound view of things sees nature as meaningful. The implication is that the significance of the things depicted in this kind of poem is simply their meaning in the world. Schlegel doesn't tell us the extent to which this is true in all poems. Jsually the objects drawn up into poetry are considered to have been given their meanings In the poetic act. The appropriateness of the symbols chosen is determined by their role in the poem rather than by their meaning as part of nature. In Schlegel's theorizing, nature arin, from man's 
point of view, share certain qualities with art. Nature can appeal to Phantagle; our experfence of nature involves language; nature can be poetic; it can be beautiful. What, then, is left to Kunstpoesie? The answer has been given before: nature is reality, art 1s fiction. This seemingly naive statement is of the utmost importance, for a flction is something consciously oreated by man, and man is that part of nature which is self-consciously reflective. Poesie is man's self-consolous use of language in a way which most adequately expresses his reflection of the world.

We must examine in more detail the nature of the transformation of the world in poetic art. Poesle uses objects from the real world, but uses them in such a way that they are poeticized and thus raised above the world. The trangformation in the case of Poesie occurs through the medium of language, so once again this subject comes up, now to be considered in its role as a number of means to achieve a poetic end.

The first requirement of all poetic devices is that they set Poesie apart from ordinary reality. To do this, poet1o language must be above that of ordinary uagge:

Fs 1st . . fur die Poesie... . Eußerst Wichtig und vorthelihaft, wenn. ale in der Sprache Mittel vorfindet, thren Ausdmack so viel môglich von dem des gewôhnlichen Lrbens zu untersoheiden. Sie kindigt damit sogleich an, daß sie s1ch tuber die gemeine Wirklichkelt erheben w1ll, und der Hörer

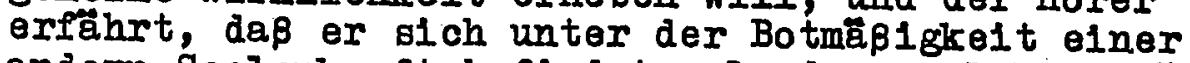
andern Seelenkraft befindet, als der, welche gewơhnIloh die Rede beherrscht. (Berlin, I, 284-85) 
88.

One means to this end we have already noted, namely, meter. Meter sets the poem in a time-sequence of 1ts own. The poem must be experlenced in successive moments determined: by 1ts own rhythm. But the demand that poetic language differ from ordinary speech is not satisfled by rhythm alone. In addition, poetry can use certain words of 1 ts own, such as archaic words, colloqu1aliams or neologiams. Poetry can have 1ts own inflections of words and there can be poetic constructions and word order.

Unlike ordinery language which appeals to Verstand, poetic language evokes vivid Images in Phantasie. While there can be synonyms in everyday ugage, they do not exist in poetry. Fach word has its own sound and makes a unlque 1mpression. As Schlegel sums up this point, "es glebt logische Synonyme aber keine poet1sohe" (Berlin, I, 287).

The ep1thet (schmilokendes Beiwort) serves to arouse vivid 1mages. Seeming redundance in the nature of this device is excuged as an effiolent means to this ond. Schlegel observes, "Bey sonst gle1chen Bedingungen 1st das bedeutsamste das schönste" (Berlin, $I, 288$ ). In the epithet a complex of associated 1deas and 1mages is oroked by means of a single word or phrase. The great beauty of the derice Iles in a compactness of meanings expressed in a few words. 
89.

Oomparison is a means for ralsing something out of ordinary reality into a higher realm:

Die Vergleichung 1st eine nach stärkere Anfoderung an die Fantasie als das Beywort, sich die Sache sinnlich vorzustellen; und duroh Zusammenstellung mit dem welter entlegnen gewinnt das Dargestellte an Größe und Wrice, und wird aus der Sphäre der gemeinen W1rkilohke1t herausgehaben, wo die Anschauung inrer Alltäglichke1t wegen keinen Werth mehr für uns hat, sondern W1r uns begnügen, die Beschaffenhelt oder den Erfolg nur begriffamäß1g horaugzuheben. (Berlin, I, 290)

Schlegel distingulshes between Vergleichung (simple comperison) and Gleichnis (alm1le):

Die Verglelchung welter auggefinrt, heißt ein Gleich-

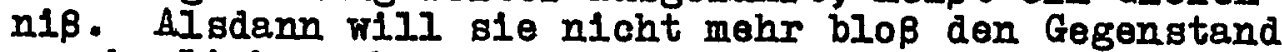
anschaulioh machen, sondern die Betraohtung mehr auf sich selbst zlehen, und in seinem Verhältnlsse zu jenem gefallen. (Berlin, I, 290)

The simile demands a certain ingenuity whioh raises it above a more prosalc comparison of two things whloh are obviously similar.

Schlegel's definition of metaphor is not unusual:

Sle besteht darin, daß man das Verglichene ganz versahwinden, und das Bild, womlt es verglichen wird an se1ne Stelle treten läßt, wodurch also nicht mehr Ihnlichke1t sondern vôlilge Glelohhe1t angedeutet wird. (Berlin, I, 291)

Metaphor resulta from a flight of phantagie and is more than a mere decoration of the prosalo. Nor is prosalc understanding allowed to oriticize the bold 1dentificatIons made by metaphor.

To this list of linguistic means for achleving artistic ends Sohlegel adds personification, another a1d to evoking vivid images. Its lowest uge is contrived 
90.

allegory. In myth we have seen the helghts to whioh $1 t$ can rise.

The tropes we have discussed here do not oome under detalled consideration in Schlegel's writings. They are treated rather briefly under the heading of "poetische Sprache." Figurea of speech refleot all those poetio qualities of language which were the subjeat of an earlier chapter in this study. The devioes just disoussed are, of course, beautiful as well as meaningful. As we are about to see, moreover, Schlegel considers meaningfulness 1tself as a necessary attribute of beauty. His definition of the term contradicts all arguments that Po.esie, or art In any of 1ts forms, appesls only to the senses.

While speaking of euphony in the Jena Iectures, Schlegel makes a distinotion between the pleasant and the beautiful. While the former 18 merely ploesing to the senses, the latter has meaning. "Tône, die nichts sagen, fthden w1r hőchstens angenehm, aber nicht schőn" (1798, p.52). The sounds of poetry, however, are both:

Das, was dem Sinne an sich wohltut, 1st euch duroh die symbolische Bedeutung des Klanges wohlgefällig. Belde, das Angenehme und das Schöne, treffen also hier in uns zusammen. Der Klang hat mannigfalt1ge Bezlehungen zu körperliche und gelstige Figenschaften, dadurch w1rd er sohôn. (1798, p.53)

Obviougly there can be meaningful statements which are not beautiful, but these are not art. An early esgay of Sohlegel'в; h1s "Betrachtungen luber die Metrik, "1s prefaced by an argument that what $1 \mathrm{~s}$ displeasing to the 
91.

senses cannot realif appeal to the aesthetic sense:

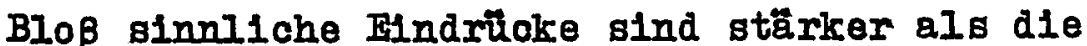
folnerm ästhet1sohen. Daher wird unfehlbar ästhetische Inst durch sinnliches Mipvergnügen zerstört; oder mit andern Worten: eire unangenehmen Materle läpt glch keine gefallende Form geben. (SW, VII, 157).

By matter and form he means here the sounds of language and their metrical arrangement. But in all art the requirements for beauty are the same, a dual appeal to the senses and to the mind. Beauty is pleasant and meaningful. In the Berlin Leotures Schlegel remarks that beauty is always "eine bedeutsame symbolische Frschelnung" (Berlin, I, 118). Later, in the same leotures, he adds, "Bey sonst glelchen Bedingungen 1st das bedeutsamste das schönste" (Berlin, I, 288).

Nature can also be beautlful but its beauty lies in man's experience of 1t. Schlegel holds that beauty is found in nature only after the disposition toward art had begun to develop. Natural beauty is not a model for beauty - in art. At the end of his disoussion of Kant in the

Berlin Lectures he states,

Immer wenn man mit der Natur anfängt, w1rd die Fristenz des Schönen als blop zufällig ersoheinen; selne Nothwendigke1t kann nur daraus hergeleitet werden, deß es seyn soll, nëml1ch duroh mensohl1che Kunst. Die Anlage zu dieser treibt den Menschen erst in der Natur Sohonheit zu suchen und zu finden. Wenn man die Naturschönhe1t und Kungtsohönheit alch unter dem Blide zweyer Sohwestern denkt, so 1st diese, gegen die herrschende Meynung, die ergtgebohrene. Frat da konnte as Schönhelt in der Natur geben, als die Anlage zur Kunst sohon angefangen hatte sich zu entw1ckeln. (Berlin, I, 88-89)

Congldering Schlegel's 1dea of beauty in general, it seems 
that beauty in ture must also be both pleasant and meaningful. Is there a difference between the beauties of art and nature? Schlegel does not deal with this problem syatematically, but the answer to the question 1s Implied in many statements on the nature of art. The essential difference, acoording to Sohlegel, lies in the fact that beauty in art is a conscious human invention. We returm at this point to Schlegel's poetic cosmology. Nature is coherent and meaningful in the sense that each part is a reflection of every other part. But In man the reflection is self-consolous. Thus in man's activity meaning, something every atom is considered to be capable of, is ralsed to a higher level (potenziert). Artist1o beauty is the pleasant and the meaningful contrived by man and for man. Beauty in axt is man's own reflection of the universe. It 1s the highest of all such refleotions because man 1s consolous of the process.

Schlegel is rether disappointing in his reluctance to use the whole 1dea of beauty in his theoretionl formulations. The two aspects of beauty are, however, considered seperately at some length. The sensuous appect of poetry 18 the object of long excursions into the subjeots of the qualities of sounds, of the letters of the alphabet and of the phonetic systems of the major Burapean languages. Euphony and eurhythmy are the objeots of similar technical disousgions. Of course, meaning is never wholly separable from sounds (whenos the formal aspeat 
of sounds disoussed earlier), but Schlegel's treatment of the พ8ys Poesie expresses meaning is centered in his discussions of other matters, inoluding genre, oriticism and poetic language. Some of the linguiatic means to poetic ends have already been congidered. A final poetic device, one which actually includes the others, remains to be discussed, namely, symbollsm.

An extreme statement of the nature of beauty arises from Sohlegel's consideration of Schelling's definition of beauty as "das Unendlich endlich dargestellt." Schlegel adds,

Hiemit bin 1oh vollkommen elnverstanden, nur möchte loh den Ausdruck lieber so best1mmen: Das Schöne lat eine symbolisohe Darstellung des Unendliahen; weil alsdann zuglelch klar wird, wle das Unendliche im Endlichen zur Frsohelnung kommen kann. (Berlin, I, 90)

Wellek dismisses such statements as borrowed flirtations with mystiol am and maintains that these thoughs are peripheral to Schlegel's poetios. I It should be remembered, however, that in Sohlegel's view Poegle is unlimited in 1ts expressive ability. If the Imagination 1s able to grasp the infinite, poetry cen certainly find the symbols to express the experience. Nevertheless, it is true that even for beauty Sohlegel is usually satisfied with the more modest claims that it merely be pleasing and meaningfur.

${ }^{1}$ A History of Moderm Oritiolom, II, 43 : 
94.

The passage fust quoted concerns us here because it leads to the matter of symbolism. Following the above discussion of Schelling's definition of beauty, Schlegel occuples himself with the question of how the infinite can be expressed. The answer 18, of course, through symbollsm:

Wie kann nun das Inendliche auf die Oberfläche, zur Frscheinung gebracht werden? Nur symbol1sch, in Blidern und Ze1chen. Die unpoet1sche Ansicht der Dinge 1st die, welche mit den Wahrnehmungen der Sinne und den Bestimmungen des Verstandes alles an ihnen fllr abgethan halt; die poetische, welche sle immerfort deutet und eine figurliche Unerschöpflichke1t in Ihnen s1eht. . . Dadurch wird ergt alles fur uns lebendig. Dichten (1m weitesten Sinne fir das poetische allen Kunsten zum Grunde liegende genommen) 1st nlchts andres els ein ewiges symbolisiren: w1r suchen entweder fur etwas Gelstiges eine äupere Hulle, oder wir bez1ehen ein Hupres auf ein unsichtbares Innres. (Berlin, I, 91)

Schlegel goes on to repeat his earlier argument that symbolizing of the non-substantial is possible because of our intuition of the essential unity of mind and matter, soul and body.

The above passage implies that Peesie 1s a way of seeing the world. This point 1s approachable within Schlegel's poetice from another direction since we have seen that language 1s present in every act of cognition. We have just found Schiegel saying that language has not lost this function when it is used poetically. "Dichten 1st nichts andres als ein ewlges Symbolisieren," Schlegel says, but 1t 18 clear that he means by gymbolizing not the invention of arbitrary signs, but rather an actual intultion of what the thing used as a sign must necessarily 
95.

mean. Whence his speaking of a poet1c view of things in which they are congtantly clarifled and seen in a figurative Inexhaustibility.

Schlegel never really makes it olear whether or not a poetlc view of things is ever manifested in anything but Poesie 1tself. Meanlngfulness in nature may be apparent to intuition, but actual meanings seem to be expressed only in Poesie which, as we have seen, is a fiational world. The problem has a Kantian aspect. The poet1c, the meaningful in nature, is postulated by Poesie somewhat as the thing-in-itself is postulated by philosophy. But aotual experlence of meaning is not immediate. Rather there is first a transformation into language through the medium of a mental faculty, Phantasie. A world within the world 1s oreated. While, just as in the case of philosophy, this world is felt to contain valid truths about our experience of things, it can express only intuitions of what 1s beyond that experience.

In the real world, Schlegel tells us, everything is a mirror of the universe, which is to say that everything has a meaning. Th1s 1s not, however, immediately and manifestIy apparent. It 1s made apparent by Phantesie. A mystic vlew of things may olaim that the meaning of objects is Immediately perceptible, but the perception in fact finds expression only in poetry which is no longer the real world but rather is nature trangformed, humanized and, in 
a word, poetlolzed.

Another world of whloh Sohlogel spears is the myth1cal world. It is a poetic trangformation of the real world, but we recall that at some time it is considered to be objectively real. Unlike the real world, it is manifestly full of meaning, yet unlike poetry (whish it resembles in that respect), its objects are believed to exist.

The world of Poosie is fiotlonal. Schlegel says that It makes no clalm to reality and we are not to be decelved Into believing that its objects and actions are real. He is aware of a problem here. Meaning in the real world and In the mythical world was considered to be a part of the essential nature of the objeots in those worlds. If the world of Poesie 1s an Invented one, then it would seem that the meanings are 1nvented along with 1t. In any statement, even a hypothetical one, about the way things really are, there 1s felt an objective and undenlable necessity whioh is somehow lacking when we speak of flotions. Yet Sohlegel olaims the same appropriateness of symbol to the symbolized which at one time or another he has claimed for nature and myth. When this condition is not met, art has falled.

A brief summary of some of the ways Sohlegel has disaussed poetry w1ll reveal his justification for the demand just mentioned. Poesie 1s a world. It is not the real world jet it has an inner coherence and meaning comparable 
to that of nature. Within this world things exist and they have, to use Sohlegel's term, a physiognomy which reveals their essence. Ultimately they reflect the whole universe of which they are a part as well as that from whioh they are taken.

Here we encounter a new slgnifloance of the fact that Schlegel sees Poesie as a world and as an organism. We recall his argument that everything in the real world has a physlognomy and the statement that everything 18, first of all, a symbol of itself since it reveals 1ts essence through 1ts appearance. Th1s is also true of things within the poetic world. Frerything must have 1ts own reality, it must be 1tself. At this point we should consider anather of Schlegel's statements that symbollsm cannot be contrived. In the Vienna Lectures Schlegel writes,

Allegorle 1at die Personification eines Begriffes, eine lediglich in dieser Absicht vorgenommene Dichtung; symbollsch aber 1st das, was die Einb1ldungskraft zwar auf andre Veranlaßungen gedichtet, oder was sonst elne von dem Begrlff unabhânglge Wirkllohke1t hat, was aber dennoch einer sinnb1ldlichen Auslegung s1ch w1llig fuget, ja sie von selbst darbietet. (SW, $V, 101$ )

The reality of poetry's abjects is obvlously reallty within a fiction, but reality it muat have. If an element in Poes1e is merely contrived to express a meaning, it fails as poetic art. Poetry's meaning is absolutely essential to 1ts very nature, but that nature must be established before this fact can be apparent. 
98.

see reallty established before meaning. He never goes so far as to deny that art is fictional, but he does on occasion suggest that the meanings of poetry's objects are the meaninge whlch are actually part of thelr nature in the real world. We have seen that this is a problemat1oal thesis and usually Schlegel does not inslst on 1t. At one point his desire to Impart a higher reality to poetry takes the form of an insistonce on a more vital role for myth. These two tendencles come together in one of the latest of Schlegel's poetlc pronouncements, h1s 1812 revlew of Winckelmann's works. This serves as a text for the conclusion of this chapter on art, nature and meaning. Schlegel must be allowed to speak at some length:

Man hat im Deutschen das vortreffliche Wort 'Sinnb1ld'. Kelneswegs mö chten 'wir der Kunst die Allogorle zum allgemeinen Gesetz machen, Wie es W. zu beabsichtigen scheint; aber wohl kann man sagen, alle Kunst soll sinnbildiloh sein, d. h. sie soll bedeutsame Bilder aufitellen. Die Natur schafft durchaus sinnbildiloh, sle offenbart immer das Innere durch das Aeupere; jedes Ding hat seine Physlagnomie, und dieses gilt von den leblosesten Frzeugn1 ssen, den geometrisoh begrënzten körpern an, durch die Pflanzen- und Thier-Welt.b1s zu den beseeltesten Geschöpfon hinauf. Diese Phys1ognomie der Dinge soll der. Kthatler hervorheben, er soll dem Betrachter seinen Sinn fur die Durchdringung des Innern loihen. $D a$ aber die Kunst nleht bel Abbildung des einzelnen Wirkliohen stehen bleiben darf, wenn sle lhren höchsten FIug nehmen soll, so 1st es das whschenswertheste, wenn $\mathrm{hr}$ Urbilder gegeben sind, an deren W1rkl1 ohkelt geglaubt w1rd, und die zugleloh sinnliche oder gelstige Figenschaften, Triebe, Bedürfnisse uns Ahndungen des menschliohen Gemuths ausdriloken. Solche Urbilder kann nur elne gehelligte Ueberlieferung darbleten. Auf der unauflởelichen Verschmelzung elnes wirksamen Daseins mit einer allgemeinen, fur alle Mensohen Fines Zeitalters, Fines Stames, Fines Glaubens gliltigen Bedeutung beruht alle uber- 
natưrl1 ohe und überhaupt alle wahrhafte D1chtung. Fs 1st aus damit, sobald der Glaube an jene Orbilder und der Sinn dafiur verloren geht. Algdann pflegt die elgentliche mit Freihelt und oft mit Wilikur erfundene Allegorie an deren Stelle zu treten. Aber umsonst: Dichten 1st schaffen [po1ein] und der Verstand 1st ohnmëoht1g zum Sohaffen; er kann selnen Finkleidungen nackter Begriffe keine lebendige Seele einhauchen. (SW, XIII, $346-47$ )

This passage ties together a number of threads in the fabric of Schlegel's poetics. Once again he speaks of physlognomy, the way in which everything is a symbol for 1tself. Foch objeot has an exterior which reflects 1ts essence. The artist brings out the meanings in things or, at least, the fact that things can have a meaning. Filsewhere we have considered Schlegel's conviotion that things not only point to their own inner essenoe but are, in fact, inexhaustible in their reflections of things outside themselves. The extreme statement of this position holds that every atom reflects the whole universe. In the passage Just quoted, however, Sohlegel seems to recognize the practical diffloulties facing a myatioal view of Poesie.

No matter how meaningful the universe and all 1tg parts may be, 1ts meanings are apparent only through Poesle. The artist, says Sohlegel, should express his own intuition of the symbolic nature of things. Perhaps the wlimate such intuition 18 that each thing symbolizes every other thing; but art presents 1mages whose meanings must be seen as Iimited, even though their meaningfulns gs 1s infinite. A.ll of nature may be symbolic, but litera- 
ture deals in individual symbols used for more or less definable purposes.

Schlegel's menition of Urbilder here is a final pointIng to myth a a model for what he meang by the literary symbol. The mythioal gods were originally considered objeotively real jet intringically meaningful for man. A national ilterature is fortunate when it has such a ready-made poetic trangformation of the world for its use. Such a world is one in which there is no problem in establishing the reality of 1ts objects since they are already thought of as being objectively real. The task of poetio creation is made more diffloult and, from the point of view of the argument in the Hinckelmann review, nearly Imposalble by the absence of such Urbilder. This is the closest Schlegel comes to his brother's Insistence on the necessity of a modern mythology. We note, however, that Schlegel st1ll centers his arguments around Schelling's view of the mythic world's reality. The requirements for true poetry are the combination of a real and effective existence with a generally valid mean1ng. Poetic invention is the creation of a world whose objects are borrowed from the real warld and put into a fictional world where they have a fictional but, nevertheless, conslatent and convincing reality. Finalig, these objects are presented in such a way that they are seen to have meanings. 
OHAPTER VI

THE AUDIEATOE'S FXPERIFITOF OF POESIE

The present chapter will consider the role of the audience in Schlogel'g I1terary theory. More particulerly, 1t w11l deal w1th how the 11terary work 1s exper1anced. Iiterature is written to be hoard or read. In a fundamental sense, it is a series of signs used to arouge a response. Poetry causes something to happen in the mind of 1ts audience. This 1s, of course, true of all 1inguist1c utterances. The difference between the experience of prosalc atatements and poems w111 first be considered negatively. Schlegel notes a number of wajs in which good I1terature does not appeal to 1tg audience. Most of these are elther suggegted or 1mplied in what has gone before, and so require little elaboration.

Poegie does not appeal to the understanding but rather to imagination. Accordingly, it does not properly have the purpose of teaching or persuading. The didactic poem 18 truly poetry only when 1t manages to rise above 1ts prosalc purpose. Voltaire is severely oriticized in the Vienna Iectures for his attempt to make art into propaganda (SH, VI, 70-73). Farlier Sohlegel had oocasion to remark that while Poesie 1s indeed phllosophioal, looking for philosophy in a poom destrojs 1 t.

Sohiegel's statements on ways Poesie should not affeotits audience are scattered through his works. The 
common denominator of all these warnings is the 1dea that

Poesie mus appeal to nothing less thatn Phantasie. Schlegel usually sees the appeal to the audience's lower nature as dellberater and attributable to a striving for mere effect by the author. Furlpides is oritiolzed for this fault.?

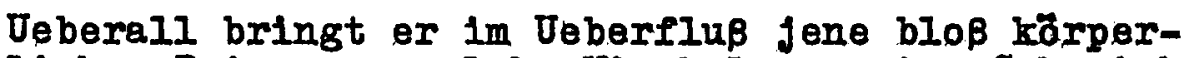
lichen Re1ze an, welche Winokelmann eine Sohmelchele1 des groben äuperen Sinnes nennt; alles was anregt, auffält, mit elnem Worte lebhaft wirkt, ohne wahren Gehalt für den Geist und das Gefuhl. Fr arbeitet auf die Wirkung in einem Grade, wie es auch dem drametischen Dichter nioht verstattet werden kann. (SW, $\nabla, 138$ )

Schlegel notes especially a blatant appeal to the emotions by Furipides. Poesie must do more than titillate or merely entertain. Poetry which seems to be concerned primarily with striving for effeat is always critloized. Further examples in the Vienna Iectures are Voltalre and Beaumont and Fletcher.

Poetry must not impress us as being reality. The greatest danger of this happening is in drama, but the princlple is applicable to all Poegle. This point is made throughout Sohlegel's writings. There is no need to elaborate 1t here since it was part of previous conslderat1ons of mimegis and the fictional world of Poesie. There 19, however, a related problem which remains to be discussed, that of the nature of the feelings which literature arouses. Granted that the action of Paesie 1s Plctional and not real, are the emotions arouged the same as thase aroused by gimilar events ocourring before us in reality? Schlegel's 
answer 1s that the emotions are similar in many respects, and we neoessarily use the seme language to desorlbe them both. Nevertheless, the experlence of these two kinds of emotions is qualitatively different. Again, it is a matter of Potenzierung, a ralsing to a higher level through an act of refleotion. Sohlegel says in the Berlin Iectures,

Schon in der bloßen Sinnesempfindung 1st das Gemith urgpringlich verloren; daß sie zum Bewußtseyn kommt,

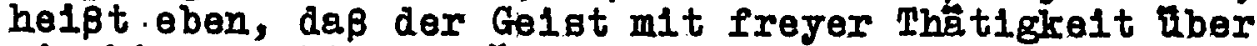
sie hinausgeht, und uber sein elgnes Verlorengeyn in der Fnpindung refleotirt: Fben dieser Akt wird nun bey der Betrachtung des Sohönen nur neoh elnem grôßeren Maßstabe, gle1ohsam in elner höheren Potenz erneuert. Fs soli und darf nichts an unserm Gefuhle selbst mit Willkuhr verändert werden, sondern wir müssen nur frey derhber refleotiren, unsre Finpfäng11chke1t selbat zum. Gegenstande unsrer Selbgtthät1gkeit machen. (Berlin, I, 24)

So the emotions felt before art are real; but they are raised to a higher level by reflection, by a helghtened consclousness of what is going on in the experience.

Iater Schlegel gpeaks of the emotions involved in musio and the IJric as being softened. They are less of a call to aotion than ordinary emotiona:

Das Wesen der muskial1schen Stimmung besteht darin, daß wir Irgend elne Regung, sel sie nun an sich erfreulioh oder schmerzlich, mit Wohlgefellen festzuhalten, ja Innerlich zu verewigen suchen. Die Fmpfindung mup also schon in dem Grade gemildert sein, dap sie uns nloht duroh Streben nach der Iust oder Flucht vor dem Schmerz uber sioh selbst hinausreiken, sonderm das w1r, unbeklimmert um den Wechsel, welohen die Zeit herbelfihrt, in einem einzelnen Augenblick unsers Daseins einheimisioh werden wollen. (SW, V, 39)

Here too we see that the emotions aroused by art (as well as those whioh ingpire 1t) exist on a different level than 
those aroused by the real world. The thought 1s introduced that the formex are weakened before there can be a destre to preserve them in art. On the other hand, they are not subject to the rising and falling in time of ordinary emotions, but rather are preserved at a constant level in the work of poet1c art.

Schlegel does not treat this problem with each ind1vidual genre, but his answer does seem to be slightly different in the arse of the drama. Speaking of the vivid presentations of the dramatic poet, he says,

Fr ruft alle Regungen hervor, die bel dem Anblick der Handlungen und Sohicksale wirklicher Menschen 1n uns Wirksem sind, und will diese Regungen erst durah die Gesamthe1t der hervorgebrachten Findrücke In die Befriedigung einer harmonischen Stimmung. auflōsen. ( SW, $\nabla, 40)$

Although Schlegel does not make the point, it might be remariced that even here he is speaking of emotions somewhat remote from our own existence. Seeing someone murdered undoubtedly arouses different emotions than those present when one faoes an attack on himself. In any asse, even in the drama the emottons of the audience are raised to another level by the context of their experience, that 1s, the drame as a whole. As we saw when discussing form, the experience of Poesie as more than a ouccession of words requires a synthetic oritical act. Here Sohlegel speaks of the whole as something posited by the poet. We conclude that if, for example, a drama leaves ue terrlfled and nothing more, then we are elther witnessing bad 
drame or else we falled as it audience to rise to the higher level of emotionel experlence which was demanded of $\mu \mathrm{s.}$

When we now look at the positive side of Schlegel's Ideas on how Poegle is experienced, we are brought back to the subjeot of Phantagie. Farlier it was soen that for Schlegel Phantagie is the faculty whereby we firat consolously experience ourselves and the world. It is the source both of myth and of Poesle. Nowi we will see that Phantagie is also the faculty through which Poesle is experienced.

The 1dea that Phantagie is set in motion by poetry has been touched on many times in the preceding chapters of this study. This was the principal subject of the discusalon of language, for there we saw that Ursprache spoke directly to Phantasie, calling up images through sounds which correspond closely to man's own experlence of the things he sought to communioate. Paogie, says Schlegel, restores this quality to language. In the words of the Berlin Lectures, "Mit dem Verstande angesehen bezaiohnet die Spraohe bloß Begriffe; die Poesie will aber darstellen, Bilder in unsrer Fantasie hervormfen, so viel an 1hr 1st wahre Ansohauung geben" (Berlin, I, 287). Poesie is both a creation of phantagie and an experience of Phantasie for 1ts audience.

On several ocosslons Sohlegel speaks of the audience being lifted Into a world of Phantasle, for example in the 
Berlin Lectures: "Dasfenige in den Darstellungen der übrigen Kinste, was uns über die gewôhnliohe Wirkliohkeit in eine Welt der Fantagle erhebt, nennt man das Poetische in ihnen..." (Berlin, I, 261). In such pasagges it appears that the real activity of Phantasie was that of the poet, whereas that of the hearer 1s merely set into motion or else, as it is put here, the hearer is ralsed above ordinary reality into an imaginative world. We saw earlier that the audience 1deally performs an act of synthes1s, whereby a succession of words is seen as a whole, as a unifled work of art. The role Phantagle plays in this process is somewhat obsoure.

When Sohlegel mentions the abllity to see the literary work as a whole he seems to be speaking merely of a mental skill and hardly of Phantasie. In the Berlin Lectures the quality of mind which makes this possible is on one occasion spoken of simply as attentiveness (Berlin, I, 25) Later, in speaking of the ep1o, he uses the term Fassungskraft but goes on to say,

Die epische Finheit besteht blok in einer solchen Zusammenfassung harmonlscher Bestand thelle, durch welohe sich die sohöne Fulle des Stoffes in lelchte und klare Umrisse fur die Fantasle gefälilg rundet. (Borl1n, I, 363)

Here he comes olose to saying that the unfiloation of the epic into a whole ocours in the audience's imagination. Usually, however, this is the business of the more prosalc procedures of critlo1sm. The subject will come up again when our attention 1s turned to the role of the literary 
cr1t10.

Whenever Sohlegel speaks of the mind's aotivity on a work of art, the subject being discussed 1s usually oritiolsm, whloh requires an analytioal point of view. But when the matter under conslderation is the immediate experience of poetry, Schlegel speaks of Phantagle being set In motion, and the audienoe's mental state seems to be passive rather than active. Thus in the V1enna Leotures Schlegel saj8, "die theatralisohe Täusohung, wie jede poetische, 1st elne wache Träumere1, der man sich fre1willig hinglebt" (SW, VI, 24). Next we must study the process of oritiolsm whloh begins when the "dream" is over and one must give an account of what has happened in 1t. The immedite experience of I1terature occuples Sohlegel's attention surpriaingly little. This experience 18, however, fundamental to all of Sohlegel's oritioal refleations on Poesle. 
OHAPTER VII

\section{IITERARY ORITIOISM}

In this chapter we are entering an area of more prosa10 and sober answers to less philosophical problems than those which have been consldered earlier. Oriticism 1s far more easily defined than Poegie. It 1s a praotical undertaking and we can almost say that $1 t$ 1s outgide the realm of literary theory. It does, however, border on theoret1oal matters at severel points and a brief disoussion of Schlegel's views on the subject is therefore in order.

In the Iight of Schlegel's view of Poesle it is hardly surprising that at times he derides the defling of poetry with the prosaic. In an Athataeum fragment, for example, he remarks that notes on a poem are like anatomial notes on a roast (SW, VIII, 12). In a more serlous mood he tells us in the Berlin Iectures that muoh more than mere understanding is needed to fathom a Work of art:

Das Wesen aller äohten Kunst und Poesle kann nicht mit dem vernunftelnden Verstande ergrundet werden: ale nimmt das ganze Gemuth in Anspruoh, sie kommt aus dem Innersten auserwählter Menschen, und so mus man sioh ihr auch in selnem Innergten mit Frnst und Ilebe hingeben, um in ihr Helilgthum eingelassen zu werden. (BerIIn, III, 4)

If one is to comment usefully on a work of art, he must first penetrate to 1ts essence. The full and 1mmediate experlence of the work, whioh we consldered in the 
preceding ohapter, oannot be bypassed. We saw there that Schlegel disoussed this experlence in rather passive terms, as something which is caused to happen in Phantas1e. Oritiolsm, hovever, is carried out with more consclous purpose and Schlegel disousses even its preIiminary steps in more active terms. The "sich hingeben" of the above passage is a borderline case. In his early (1795) commentaries on Dante he speaks of "elndringen" and "glch hineinträumen" ( $\underline{\mathrm{SW}}, 200,202$ ). Schlegel's most thorough theoretical treatment of crlt1clsm occurs early in the Berlin Leotures. The problem he deals with there is fundamental to all critic1sm. Art strives for the immediate impression on our feelings. But feeling and judging seem to be irreconcllable opposites:

Thpfinden 18t . . gerade das entgegengesetzte. von beurtheilen; jenes dritokt ein passives, dieses eln aotives Verhaltnis gegen den Gegenstand aus. Fa fragt sioh also: Wie 1st Kritik iberhaupt möglich? (Berlin, I, 23)

How can we orftiolze without destroying the feelings art arouses? The answer 1s found in Schlegel's Flchtean view of the human mind. Animals and young ohildren are lost in their feelings, but refleotion brings feelings in men to consclousness and raises them to a higher

\section{level:}

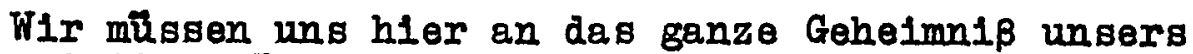
geistigen Daseyns erinnern, welches nichts anders 1st als ein beständiges Pulsiren zwischen einer nach aupen hin sioh verbreltenden und elner in sich selbst zurthokkehrenden Thätigke1t. Sohon in 
der bloßen Sinnesempfindung ist das Gemith urspringlich verloren; das ale zum Bewustweyn kommt, heipt eben, daß der Geist mit freyer Thât1gke1t uber sie hinauggeht, und uber se1n elgnes Verlorenseyn in der Fmpfindung refleotirt. Eben dieser Akt wird nun bey der Betrachtung des Schönen nur nach elnem gröperen Masatabe, glelchsam in olner höheren Potenz erneuert. (Berlin, I, 24)

There is no need to alter the feelings aroused in the immediate experience of art. Oriticism is made possible by free reflection on these feelings.

Schlegel's concise definition of oriticism is that It is the skill of judging works of art (Berlin, I, 23). He combines this definition with the 1deas discussed in the preceding paragraph and observes that judgment 1tself consists essentlaliy in making comperlsons and distinctions:

Der Findruck bey der ersten Bekanntachaft mit [schönen] Gegenständen 1st ein frohes aber gänzlich unbestimmtes. Frstaunen, wie jeder Mensch sich aus seiner Kindhelt wird zu erinnern wissen; erst duroh häufige obung daran bekommt die freye Thatigke1t Im Gemithe die Oberhand, und es lernt verglelohen und unterscheiden, also urtheilen, indem dieß ja nichts andres 1st. (Berlin, I, 24)

He goes on to say that judgment requires the ability to synthesize, to draw together a whole serles of impressions Into one unified impression of the art work. These thoughts were consldered earlier in the ohapter which dealt with form. In the case of the arts which make their presentations in successive moments in time, the formation of a unified impreselon of the whole may be extremely dificult, but it is nevertheless essential that this be done. Works of art are, in fact, unfifed 
wholes and the fallure to see this can lead only to bad criticiam. The criticism of "correctness" is Schlegel's prime example. This kind of criticism deals only with the smallest parts of the work and Schlegel accordingly calls it atomistic oritiolsm:

Man könnte dieß die atomist1sohe Kritik nennen... indem.sie ein Kunstwerk wie eine Mosa1k, wie elne mühsame Zusammenfiugung todter Partikelohen, betrachtet; da dooh Jedes, welches den Namen verdlent, organ1scher Natur 1st, Worin das Finzelne nur vermittelst des Ganzen existirt. (Berlin, I, 25)

Oriticism must, then, see the poem as organio if its judgments are to be valid ones.

Schlegel next considers the problem of how literary judgments can be more than subjective. The answer is baslcally twofold: the critic must be consclous of the purely subjective element in his experience of a work; and he must be in a position to make appropriate comparisons between the work and things outside $1 \mathrm{t}$.

When we read a poem, for example, we may be influenced by a mood which will affect our experlence. Th1s does not, however, necessarily preclude the possibility of objective Judgments:

Man erhebt sich tiber die Stimmung gewlssermaßen schon dadurch, das man slioh ihrer bewript 1st; denn alsdann kann man slchs klar machen, wie etwas in einer andern Stimmung ungefähr auf uns gew1rkt haben wurde. (Berlin, I, 26)

Consclousness of the subjective allows the critio to see beyond 1 t. 
Schlegel continually reminds us that objective Judgment is posgible only for those who have a knowledge of many works of art. Only by comparing such works can we judge the excellence of one of them. The objecta of comparison must be appropriate ones:

Object1v, ubber ungre Person hinaus gülig, kann [das Orthe11] nur dadurch werden, daß die Vergleichung mit solchen Gegenständen angestellt worden, die wirklich dazu gehören, und elnon wahren Masstab der Vollkommenhelt abgeben kônnen, welohes denn keine andre sind, als die vortreffliahsten Werke derselben Kunst in verwand ten Gattungen. (BerI1n, I, 26)

Here we see the importance of Iiterary history for literary oritiolom. The former provides us with, points of comparison, evidence of similar Influences and with knowledge of Ilterary schools. The critlo must have a knowledge of philology and of history in general, the latter in order to show the place of the work in the history of mankind's progress. In Schlegel's preface to the 1828 edition of his Xritisohe Sohriften he says,

Wie die schôpferische Wirksamkelt des Genlus Immer von elnem gewlssen Unbewustsein begleitet ist, so fällt es auoh der begelsterten Bewunderung schwer und, je ëchter sie 1st, um so schwerer, zu besonnener.Klarheit uber sich zu gelangen. Am besten wird es damit gelingen, wenn die Betrechtung nlcht vereinzelt wird, sonder vielmehr den menschIlchen Gelst in den Stufengenge selner Intwiakelung bis zu den Gipfel hinauf begleitet. Mit einem Worte, die Kunstkritik muß slch, um 1hren großen Zweoke zu leisten, mit der Geschichte, und, so fern sie sich auf Poesie und Ilteratur bezieht, auch m1t der Ph1lologie verbilnden. (ST, VII, $x \times x$ ) Theory also plays 1ts part in orlticism, for critical statements can be clearly expressed only when they are part of a 
system whloh, however, does not necessarily have to be expressed. Theory, criticiom and history are intimately related. Oriticism produces theory: "Dle kritische Reflexion 1st eigentlich ein beständiges Bxperimentiren, um auf theoret1sche Satze au kommen" (Berlin, I, 27). Or1ticism is further vital to both art history and art theory because only in criticism do works of art become objeots for these studies, "denn bejde haben es ja nicht mit den Kunstwerken zu thun, In so ferm sie elne äuperliche Masse in der Sinnenwelt ausmachen, sondern mit ihrem Geiste, den w1r nur in uns selbst erforschen können" (Berlin, I, 27). In spite of the critio's best efforts his criticiam 1s always partially subjective. Accordingly, he must make his personality apparent to his readers. Sohlegel's dictum on th1s point is: what of necessity must be ossentially individual, let $1 \mathrm{t}$ also be so in form (Berlin, I, 28). This statement is the basis of Sohlegel's criticism of the anonymity which was usual for the reviews of his day, in his essay "Ūber kritische Zeitschriften" (SW, XII, 8-9).

The individuality of critiolsm leads to many different statements about the work of art. This diveraity might produce skeptiolsm about the validity of oritical judgments. But Schlegel does not share such skeptlol sm. Rather, he says, different men look at a worik from different points on a circle, as it were. They desoribe different radil but 
114.

but they can nevertheless all nave the common conter in จ1ew.

In the Berlin Leotures (I, 28-29) Sohlegel denies that the connolsseur of art has to be an art1st. The critlo cannot be reproached with his inability to write a poem better than the author. He can, however, demonstrate In general that the poem could in fact have been better written. On the other hand, the artiat does not have to be a connolsseur, although judgment cannot be ent1rely lacking if his work is not to degenerate into eocentricity and extravagance. Schlegel's higheat demand of the good crltio is genuine: Kennerschaft, which demands universality of knowledge and 1nterest:



This quality is not demanded of the practioing artiat who must of necessity concentrate his attention on the work at hand.

A further requirement for being a good critio is enthusiasm. Th1s 1s actually a repitition of Schlegel's statement that art must be experienced immediately before 1t can be crltiolzed. The cold critlc betrays a lack of feeling for the work of art: 
Was mit dem Gefuhl nioht aufgefaßt wird, 1st in dem Kunstwerke fur uns niaht vorhanden; Fmpfänglichke1t ist also das eine werentliche Frfodern18 zum Kenner, und in so fern 1st der wârmste Kritiker auoh der beste. (Berlin, I, 30)

Sohlegel suggests Winckelmann as an example of the warm and enthuslastio oritic. The cold, purely intellectuel oritio 1s, for Schlegel, exemplifled by Lessing.

Taste is defined by Sohlegel as the abllity to judge the beautiful. This definltion prompts him to. stress again the theoretiaal nature of or1tiolsm: "Kritik müpte denn etwa im Sinne der kritischen Philosophie genommen seyn, dann hieße es: eine Untersuchung liber die Gllt1gkeit der vom Geschmeak abhänglgen Urthe1le" (Berlin, I, 31). He goes on to speculate on the reasons why we use the word "taste" rather than, say, hearing or sight to describe our receptivity for art. He concludes that the term is appropriate because tasting 1s so inward and 1ts objeots are combined with ourselves in the experience:

Es erfolgt dabey w1rkl1ch eine chemische Auflögung und Verbindung des Gegenstandes mit dem aufnehmenden Organ, und dadurch unsrer ganzen Organlsation. Hierin liegt also die Ahnlichke1t mit dem Innern Sinn fitr das Schöne. (Berlin, I, 32)

Schlegel also remarks that physical and artiatic taste are further similar in that for both we have relatively few words to describe their subtle nuances.

Sohlegel recognizes the fact that tagta, as most people use the term, oan mean little more than a cult1rated sense for certain superficial elements in art. At 1ts lowest level it becomes mere fishion and changes with 
the times.

We have already examined Sohlegel's views on the role of criticism in the triad history-oritloism-theory. A statement in the V1enna Leatures states 1ts mediating role conclsely. Orit1o1sm 1s the connecting link between history and theory. "Die Kritik ist es, welche die Gesohichte der Kunste auficlärt, und 1hre Theorle fruchtbar macht" ( $\mathrm{SW}, \mathrm{V}, 4$ ). If, however, we inquire bejond this ofrole of approaches to the study of literature, we find another object of oritiolsm in 1ts raising less gifted members of art's audience to the point of view of the critic. This is expressed best in the essay on Shakespeare and W11helm Meister:

Der Genuß edler Gelsteswerke 1st unabhëng1g von [der Kritik], denn er mus ihr vorangehn; sle kann Ihn elgentlioh nloht erhöhen, wohl aber thm Vieles abzlehen, auf's höchste 1hn zerglledern und erklären. Ihr rithml1chstes Geschät 1st es, den grapen Sinn, den ein schópferlscher Genius in selne Werke legt, den er oft im Inneraten Ihrer Zusammensetzung aufbewahrt, rein, vollständig, mit scharfer Bestimmtheit zu fassen und zu deuten, und dadurch wenlger selbstständige, aber empfängliohe Betrachter auf die Hohe des richtigen Standpunktes zu heben. (SW, VII, 26)

Sohlegel adds that critlaism's posglbilities are seldom fulls reallzed. It almost takes an artist to express adequately what 1s experlenoed, as distingulghed from what is merely thought out. Of course, Sahlegel is here concerned with Goethe writing on Shake speare. Filsewhere the highest requirement of the oritic is not oreativity so much as it 1s universel knowledge. 
Much of what we call historloal critlolem is allowable within Schlegel's conoept of oriticlam, for he 1s always concerned with the place of the work in the history of 11terature and with the value of the work in comparison with others of 1ts kind. Blographloal orlt1olom 1s, however, another matter. In his own oritiolsm Sohlegel rarely deals with biography, and in his theoretical writings he dentes: its importance in prinoiple. In his essay on Burger he says that a poem is as much separated from the poet as frult from a tree, implying that the enfoyment of each is independent of any knowledge of 1ts origin (SW, VIII, 70).

Schlegel does speak of the meaning put into a work by 1ts author, for example in the pasage from the Shakespeare-Meigter essay quoted above. To this might be added a similar statement in his 1797 review of

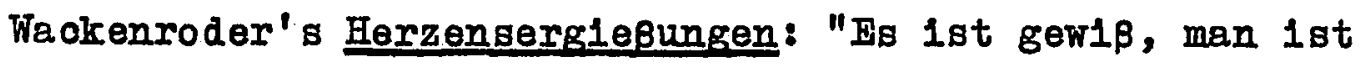
nicht eher befugt zu richten, b1s man ein Kunstwerk ganz versteht, bis man tief in seinen und seines Urhebers Sinn eingedrungen 1st" (SW, $X, 364)$. But he goes on to suggest that this is accomplised through a quality of the critia's mind, above all, his receptivity for what 1s there.

If one admits the significance of the author's intention, the only way to deny the relevance of biography is to claim that intention is revealed completely in the work 
1tself. This 1s Implied but not explicitly atated by Sohlegel in his theorizing on crltiolsm. On the other hand, his denial of blography's importance is consistent With his view that poesle is a complete and coherent world in 1tself.

In the essey on Shakespeare and W11holm Me1oter Sohlegel has occasion to compare confused attempts at Iiterary art with the produations of true genius. The former are muddy streams, the latter clear and still waters into which each man an look as deeply as he is able:
Jene entweder in der Ausfihrung verfehlten, oder sohon in der Anlage verworrenen Darstellungen, wovon 1ch oben gprach, könnte man m1t trüben Strömen vergleichen, worin das schërfste Gesicht.so wenls etwas untersche1den kann, als das blödeste; die Werice des achten Genius hingegen mit elnem reinen und stillen Waßer von unermeplicher Tiefe. Sollte auch keln Auge ganz bis auf den Boden dringen, so findet doch jedes fur seine Sehkraft Befrledi- gung: denn so welt diese relcht, erbllckt es die in dem fliksigen Filemente entheltenen Gegenstände volikommen deutlich und unentstellt. Nur der 1st durch elgne Schuld 1rrigen Vorstellungen ausge- setzt, der alch elnbildet oder anmakt, tiefer zu sehen, als er wirklich sieht. (SW, VII, 3I)

To this should be added the fact that the critic can ald the less vigilant to see deeper. But even the oritic 1s subjeot to the final admonition: only error can result from imagining that one sees deeper than he actually does. In sonolusion we should note that (although it 1s jugtifled in theory) very little of Sohlegel's own orit1clam deals with explications of literary works. Rather, 
It refleats his liea of crlticlam as the mediator between history and theory. Oritiolsm is judging, determining the worth of a poem in relationshlp to others of 1ts kind. Orlticlsm both uses history and adds to it a new ohapter. So 1t is too in the case of theory: criticism uses theory as a framework for 1ta statements and new theoretioal premises arlse out of oritiolsm. 
OHAPTER VIII

\section{THEORY OF GEHNRS}

To survey all Schlegel has sald on the subject of genre would necessitate examining his critical works in some deta11, for 1t is there that he develops most of his 1deas on what the genres should be. Since our subject here is literery theory and not literary orit1oim as such, there is no need to digest this huge amount of materlal: We are not concerned so much with the problem of what characterizes the individual genres a $\mathrm{w}$ th the problem of how the 1dea of genre fits into Schlegel's poet1cs. Even so, this is hardly possible without an examination of the main classic and romantic literary types. In this ohapter the subject will be treated in a survey of Schlegel's thoughts on the ep1c, Iyrio and drama. Iater, in a chapter on romanticism, his statements on the romantic genres will be examined for the light they shed both on the subjeat of genre and that of romantioism.

In the Jena Iectures Schlegel remerks that the philosophical derivation of the genres seems to be the highest takk of striotly scientific poet1es (1798, p.111). He goes on to say that he will take the easier way and derlve them historically. By this he means that he w1ll characterize the genres according to known examples, beginning with the three basio classical types and 
proceding to those which are compounds or derivetives of these. In the Berlin Iectures he indulges briefly in a morephilosophlcal approach. He speaks dialectically of epic, Iyric and drama as thesis, antithesis and synthesis and suggesta their relationshlp ta the Kantlan oategorles. The three genres are characterlzed as "Lelohte Fille, energlsche Finzelnhe1t, harmonlsohe Vollständigke1t und Ganzhe1t" (Berlin, I, 357). He adds these remarks: "Das Epische das reln objective im mensohlichen Geiste. Das Iyrische das rein subjectlve. Das Dramatische die Durchdringung von beyden" (Berlin, I, 357). Outside of a few such scattered speculations, Sohlegel's approach to genre is descriptive and historical.

We recall that Sohlegel's principle of diviaion. for the arts in general is twofold, according to the way they present their objects in time (simultaneously or successively) and according to their mode of expression. Poesie, for example, 1s distingulshed from the other arts by 1ts use of language for 1ts presentations and It is further distingulshed from sculpture and painting by the fact that it must present objects auocessively. There are no such easy ways to distingulsh the poetio genres. Sometimes Schlegel speaks of mood, often of content and often, too, of metric form. But all these a ppects of a specific genre are interdependent, and definitions here consist of lengthy desoriptions. According to Schlegel's speculative hlstory of Poegle, 
the genres appear at the time of trangition from Naturpoesie to Kunstpoesie. Whenever poetry beoomes consclously produoed art, it falls into one of the three besic categories. The creation of art 1s a free activity, but this freedom 1s alweys exercized within certain restrictions, and one of these 1s genre. Without boundarles art falls into confusion (Berlin, III, 183). In the Berlin Iectures Schlegel teils us that organization 1s, in faot, a condition of free individuality:

Allgeme1n betrachtet, 1st ein gewlsses Gesetz der Form sogar Bedingung freger Individualität in der Kunst wie in der Natur, denn was zu keiner Gattung von Organisation gehốrt, 1st monstros. (Berlin, III, 69)

Necessity of form.1s no restriction on the poet's freedom, nor is the oategorization of the finished work a denial of 1 ts individuality.

The genres multiply in time. At first there were only the three besic types, with the added distinotion of tragedy and comedy w1thin the dramatic. But later new genres were added to answer new needs for expression. Often 1t 1s difficult to deolde whether the new ones are genuine or are merely mongtrous hybrids. In general, Schlegel insists on purity of genre and criticizes any admixture of inappropriate elements. Romant1c art, however, is a case in itself and we must consider 1ts mixed genres separetely in a later chapter.

Schlegel begins his disoussion of the eplc in the Berlin Iectures with the definition which appeared 
earlier in his Bermann und Dorothea essay and in the Jena Lectures. The eplo is "eine ruhlge Darstellung des Fortsohreitenden" (Berlin, I, 358). The eple point of view is purely objective. The epic poet is calm and impartial. His objeotlve view of his material is completely unclouded by emotion.

These thoughts lead Schlegel immediately to the question of the relationship of Poesie to movement. Poesle, we recall, 1s successive. Schlegel holds the essentlally Kantian view that the succession in time of movements which we perceive is a mode of perception, something added by the mind to external reality. Poesie is admirably sulted for portraying such experience since language cen follow, step by step, the mind"s ordering of the world into a series of events in time. Since the epic strives to be as objective as possible, it prefers to deal with movement, with things which are precelved in just the order that the poem will record them. Schlegel next deals with the problem posed by Lessing, of how Poesie can deal with things at rest. Since Poesie 1s successive, there is felt an incongrulty of matter and form when 1t deals with motionless objects. Mere desoription is generally ungatisfactory since it is limited by the audience's ability to reconstruct the pioture out of a number of parte. In Schlegel's view there are two ways poetry oan portray things at rest, both of them being compromises. First, the poet can describe feelings about the object since 
these emations are succegsive in time. In doing this, however, the object becomes of secondary importance and the emotions themselves the matter of primery concern. This is to say that such a poem is by nature 1yrio. The second way of portraying rest is to transform it into motion. This is the way of the epic. Sohlegel credits Lessing with this observation but criticizes him for saying that it is the only way in which Poesie con deplet (Berlin, I, 359).

Out of these thoughts comes the interesting observation that the didactic poem is properly a subgenre of the epio. In a sense the lesson in such a poem is a whole which is at rest, but it is turned into a succession of 1deas when 1t is made into a poem (BerIin, I, 360). At 1ts best it should also have the calm and objeotivity of the epic.

Since the epic always deals with objective events in time, its form is always narrative. This narration; moreover, 1a characteriatically epic:

Fs glebt leidensohaftliche, rhetorische und mimische Frzählungen; die eplsche hingegen 1st unparteyisch, und von keinen Iußerungen der The1 lnahme unterbrochen; sle sucht durch Anschaul1ohke1t aber nioht durch Versterkung und Obertrelbung au wirken, und endilch.nimmt sle zwar die Reden der handelnden Personen in sich auf, aber nlcht so das der Erzähler sloh ganz in diese versetze und sich selbst darüber verlöre, sondern or bildet sle zur Gleichartigkeit mit.den ubrigen Theilen der Frzêhlung um. (Berlin, I, 361)

Thus the manner of narration must never violate the nature of the genre which 11 es in 1ts oalm and objectivity. 
This objeotivity leads Sohlegel to say that in the ep1c everything must have the appearance of chance. Necessity 1s, as he puts 1t, a "Oonstruation aus Gesetzen unsers Gelstes" (Berlin, I, 361) and hence subjective. Here the ep1o is contrasted to tragedy whose subject is the polarity of freedom and necessity and wherein nothing happens by chanoe. The chance events of the eplc easily accommodate the appearance of the gods and the miraculous in general, the very denial of causality. The epic is more at home in an age when men do not have a strong sense of oausality and determination. Men appear in the epic like seemingly accidental physical powers of nature. There is no real unity of action in the epic. As Schlegel explains,

Nur duroh einen Akt der Freyhe1t kann etwas aus der unendlichen Re1he von Naturerelgnissen herausgerlssen, und das aus jenem herfließende, die Hendlung, $z u$ einem in sich beschlossenen Ganzen gemacht werden; und ein soloher Alkt der Freyheit liegt Jenselts der Außenwelt, welche das thos sohlldert. (Berlin, I, 363)

The materlal of the epio is more a plurality than a unity. whole and each is also divisible into smaller parts. There are no flxed boundarles to the ep10. The story could be added to, and the only limit on such expansion

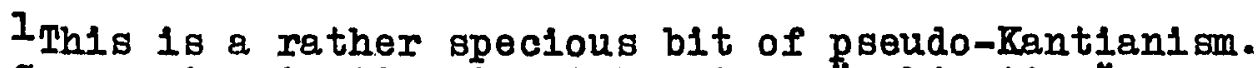
succession in time is at least as "subjective" as causality, but Schlegel makes of the former the very essenoe of the eplc. 
is the audience's powers of comprehension. The only unity of the epio is in the Phantagie of the audience:

Die eplsche Elnhelt besteht bloß in elner solchen Zusammenfassung harmonischer Bestandtheile, durch welche sioh die sohöne Frille des Stoffes in lelchte und klare Jmrisse fur die Fantasie gefallig rundet. (BerIin, I, 363)

Fven so, each part of the eplo seems to be a whole in 1tself. Unlike other genres in which expectation and 1ts satisfaction are part of a unifled progression, these are, In the ep1c, spread equally over the whole. All parts are equal and the epic could begin or end at almost any point. Its order of events seems quite natural, although It is not necessarily bound to objective time. Rather, the eplo is quite often eplsodical, fumping back and forth in. time. Epic calm demands of the poet such a mastery over his material that the varlous parts are actually of Indifferent value to him. Accordingly, he does not try to lend a false helghtened real1ty to past events. He tells of them as if they were present.

The ep1o creates a poetic reality for us. An epic poem Iingers on details. Its actions pass before our eyes undisturbed by the subjectivity of the poet. Its time sequence 1s poetic. We can even say that 1ts time structure 1s characteristicalis ep1c. Things whioh last in the real world can take only a moment in the eplc, whereas It oan linger over the transitory. Everything 1s appropriate to the genre. There is never a laok of motion 
and never an 1nappropriate hurrying over things. Fvery moment seems to have its own value:

Der Sänger verwe1lt bey jedem Punkte der Vergangenheit mit so ungethellter Seele, als ob demselben niohts vorhergegangen wäre und auch nlohts darauf folgen sollte, wodurch das Frquickliche einer lebendigen Gegenwart uberall glelohmäß1g verbreitet wird. (Berlin, I, 366)

In short, in each of its parts and at all times the epic reflects 1ts characterist1c nature. This is also true of 1ts apeeches, for they are neither like those of ordinary reality nor those of the drama. They are not to be Judged by standards from other provinces. Here, too, there is no striving for a goal. In fact, all the epic traits are found in 1ts dialog:

Jedes, wodurch das Folgende vorbereitet wird, scheint dennooh nur um sein selbst willen da zu stehn: ganz das Verwellende Fortschreiten, die sinnlich belebende Umständl1 ohke1t, die besonnene Anorónung, die le1ohte Folge, die lose Verknupfung, wie im Fpos uberhaupt. (Berlin, I, 367)

This consistenoy of each part with the nature of the whole is seen in the smallest parts, in the speeches, the ep1sodes, even In I1terary devices such as the simile (Berlin, I, 367 ; SW, XI, 194). Schlegel shows that the hexameter 1s profoundly appropriate to the eplc since this verse form reflects a lack of direction, the epic's easy trangitions, 1ts unhurried progress, 1ts calm (SW, XI, 192-93; Berlin, I, 370).

The Iyrio is the musical expression of emotions by means of language. This definition is followed in the Vienna Iectures with the statement that the emotions preserved in 
the Iyrlo are softened. The Iyric presupposes pleasure in the preservation, but for this to be the case the emotions must no longer be strong enough to cause us to seek the pleasure or to flee from the pain which brings them about (SW, V, 39).

In the Berlin Iectures (II, 231) the Iyric is characterlzed as being, in almost ali respects, the very opposite of the ep1c. The latter is universal, expansive, outwardly directed, objective, and by means of presenting objects it reveals a calm observing mind. The Iyric 1s particular, concentrated, Inwardly directed, subjective, and in 1 t the outer world appears through the medium of an emotional spirit ("eines bewegten Gemithg") which is itself presented in the poem. A noteworthy characteristic of the Iyric is its individuality, but Schlegel tells us that it can not be completely subjective If it is to be art. He uses the 1dea of style whlch he developed earlier, that it is freedom exercized within the bounds of an art princlple.

It 1s, at first sight, remarkable that the shortest of the major literary types has the most complicated verse forms. Schlegel explaing that this is so because of the individuality of the emotional states which are portrayed. The multiplialty of possible verse forms is acoompanied by a much greater strictness within the forms. The Iyric permits fewer deviations from the striat metrical 
and strophio successions which the mood of the individual poem has determined.

Subjectivity and Individuality are as fundamental to the Iyric as objectivity and universality are to the ep1c. In addition to those just considered, there are further results of this fact. The boundlessness of the emotions permits the boldest use of language. The lyric has the greatest freedom of all the genres to use unusual words, constructions and flgures of speech. The language used is colored by the emotions involved and by the individuality of the poet.

The Iyric is not, however, completely without limitations. We have already seen two of its limitations in the above discussions of style and meter. In general, the only bonds placed upon it arise from the demands of art. As art, 1t must be beautiful and, in Schlegel's view, this rules out its portrayal of contradiotory or discordant emotions. Just as in music, the only dissonances allowed are those which can be and in faot are resolved within the work (1798, p.134).

Pinaliy, the unity of the lyric. is in 1ts prevaling tone (1798, p.136). Emotions are rarely simple but rather are usually complex feelings pointing in many different directions. Similar and related emotions set the tone of the Iyric poem and others must be subordinated to these. By this means the lyricist lends his emotions 
an artiotic unity.

Sohlegel's theory and criticiem of the drama oan only be dealt with here in broad outline. Schlegel atudied the drama in greater depth and breadth than any of the other genres and he devoted an entire series of leotures to this subject alone. Our puxpose here is to survey the resulting theorles and to see what they contribute to the 1dea of genre.

Discussion of the clasgio drama is complioated by the faot that it 1s actually divided into two suh-genres, the traglo and the comic. Furthermore, even in classical times the latter ohanged in oharacter and became an essentially new genre. Insofír as the drama as a whole can be oharacterized, we can only speak of form and external appearances: Drama presents actions by means of dialog, and It must be sultable to be played on the stage. The events presented are given a greater appearanoe of vividness and reality and the emotions drama excites in Its audience are stronger and more immedate than those of the Iyrio. The dramatic poet 18, moreover, far from being the objective observer of the eplo. He is far from indifferent toward his charaoters and ho must agsume a definite attitude toward human Ife. He brings his audience to participate in the same attitude (SW, V, 40). When we come to the distinction between tragic and comla, we find that these dramatio types impose striat 
Iinftations on content. Whereas the provinae of the epic is the whole objective world and that of the Iyrio the whole range of human omotions, tragedy deals only with the problem of man's nature, specifloally with the problem of freedom versus necessity. Sohlegel's defin1tion of tragedy in the Jena Irectures 1s this: "Die Tragôdle lat die unmittelbare Darstellung einer Handlung, In weloher der Stre1t zw1schen der Mensohhe1t und dem Schlckgale in Hermonie aufgelögt wird" (1798, p.161). Subsequently he relates the 1dea of action to that of freodom by saying, "Handlung in strengen Sinne 1st Riohtung der Kraft durch Freiheit" (1798, p.163).

As in the case of the other genres, in tragedy every detail is influenced by the general purpose. Freedom is seen in man's self-determined action, and necessity is determination above and beyond man. In sharp contrast to the ep1o, nothing happens by chanoe in a tragedy. All 1s governed by the will of man or of fate. In the eple the gods are drawn into the human world. There man can struggle with them even physloally. But in tragedy they are elther instruments of desting or are themselves in a struggle with a necessity higher than themselves (Bexlin, II, 318). In the eplo the miraculous 1s oharming, in tragedy it 18 awesome.

Sohlegel also states the role of tragedy as that of establishing the olaims of the mind to divinity: "die 
Anspritohe des Gemüths auf innre Gottliohke1t zu behaupten" (Berlin, II, 318). All Iimitations of man's lowar nature are overcome. The sublime speotacle is of the highest dignity, and this 1a reflected throughout the tragedy. Men must be of the greategt strength and human worth commenourate with their role in the drama.

A word should be sald about the traditional dramatio unities. Let us reverse the order in which Schlegel deals with the unities in the Vienna Lectures and consider time and place first. Schlegel disposes of these quickly on the grounds that they are not essential to Poegie in general. Poetry is fiotion, a waking dream. Poesie does not deoelve us that it is Iiterally true, and a poetlo fiction does not follow the laws of the objective world but rather Its own laws which are those of imagination. Our thoughts very easily jump over distances of time and space and it 1s a completely artifioial limitation on the mind and on Poesie 1tself to deny them this prerogative.

The only one of the unities which deserves to be called the true unity of the drama is unity of aotion. Schlegel show the inadequa of of the naive definition of action as simply something that takes place. A better definition of Handlung is thet it is an activity dependent on man'g w1Il:

Im höheren elgentliohen Sinne 1st Handlung elne Fon dem Willen des Menschen abhängige Thëtigkeit. Ihre Finheit wird in der Rlohtung auf ein einziges Zlel bestehen; zu ihrer Vollatandigkeit gehört 
alles was zwischen dem ersten Intsohluße und der Volibringung der That liegt. (SW, VI, 14-15)

Even when action 1s so defined, however, it is obvious that drama could portray a disconnected series of such events. For aotion to be unified, it magt atrive without deviation toward the end whioh is the essence of the drama. In tragedy this essenoe 11es in the 1dea of freedom, the assertion of free will and the ultimate reoognition of necessity:

W1r haben in dieger Bezlehung auf eine höhere Idee allerdings die Finhelt und Ganzheit der Tragödie im Sinne der Alten gesucht: nâmlloh ihr absoluter Anfeng 1st die Bewebrung der Freihelt, die Anerkennung der Nothwendigkelt ihr absolutes Finde. (Sif, VI, 17)

We see that Sohlegel has desoribed not just unity in generel, but a unity appropriate to a partioular genre. Here it consists in the subordination of all action to a single 1dea.

Sohlegel also considers dramatic unity from a subjeotive point of view, for whioh he borrows from the French oritic De la Motte the term unity of interest. Properly defined, this term 1s the most sultable for drame's unity:

Falls man das Hort nicht auf die Thollnahme an den Schickalien einer elnzigen Person beschränkt, sondern wenn Interesse luberhaupt die Rlahtung des Gemthth be1'm Anbliak elner Begebenhelt bedeuten soll, so móchte 1oh diese Friklerung die befrledigendete und der Wahrhe1t am nëchsten kommende finden. (SW, VI, 19)

Sohlegel goes on to remark that the 1dea of a whole does 
not oome from experience but rather from the aotivity of the mind. Oong1dering the matter of unity, again from a more objeotive point of view, it oonsists, negatively speaking, in the absence of disruptive eloments which would prohlbit understanding, imagination and feeling, all working together, from percelving the work as a whole. This implies the necessity for tragedy, bound as it is to an 1dea, of a logioal connection of its parts.

Sohlegel's definition of comedy in the Jene Irectures Is that it is "die unmittelbare soherzhafte Darstellung menschlloher Oharaktere in elner Handlung" (1798, p.179). In contrast to tragedy, comedy has the appearance of oaprlolous play directed to no definite end. No appearance of serlousness, logical order or verisimilitude 1s required. Bren the laws of dramatic presentation may be set abide. The poet can even appear on the stage and eddrese the audienoe in his own person.

In the Vienna Ieotures there 18 an elaborately drawn contrast between the traglo and the comlc mood, between Frnst and Soherz (SW, V, 41-43). The former is the state of mind resulting from a deep sense of tension between man's many human Iimltations and his divine nature. Soherz, on the other hand, is the forgetting of all serlousmess in a present sense of well being. Man's limitations are no longer the objeot of lamentation but rather of laughter, though it i's a sublime laughter. Comedy entertaing the mind and pleases Phantagie. Although an element of 
earnestness was later mixed with comedy, in 1ts earliest form 1t was pure sport and in complete contrast to Greer tragedy.

In most of his theorizing on comedy Schlegel speaks of Greak 01d Comedy. It 1s the opposite counterpart of tragedy. Purposeless fun and unrestrained caprico set the mood. Yot 1t 1s still art. It atill extends just as far beyond the limits of reality into the realm of free creat1ve Phantagle as does tragedy (SW, V, 147). Comedy portrays humorously the domination of man by his lower nature. In a sense it is a parody of tragedy. This parody is made complete by the use of the chorus, the 1deal spectator in tragedy. The parody of traglo form is also seen in the destruction of dramatio illusion by drawing the audienoe into the play (SW, V, 150).

New Comedy is an impure genre. It mixes earnestness with sport. Verisimilitude is again required. New Oomedy is earnest in form and is realistic. It has coherence whioh, however, is derived by reference to reality rather than to an idea, as in tragedy. St1ll, it is art insofar as it is formed into a flotional whole, follows theatrical laws, exoludes the superfluous and assumes a more distinct appearance than the vague outlines of everyday reality. Sohlegel eummarizes these points by saying that It is poetic in form but proseic in content (SW, V, I79). Sohlegel elaborates all these theorles in great detall. As 1s his usual prooedure, he develops h1s ideas from 
orltiolsm of actual works.

We have already noted that one way a new genre oan develop is through the parody of another one. Other genres are also developed to fulfill different needs for expression. Sohlegel considerg all the lesser olassic genre日 as subtypes of the basic three, which they resemble in varying degreas. By the time we reach moderm times, however, the relation of the new genres to their claselo arohetypes becomes less clear, and the best way to explain their origin is to point to the new poetic needs which they satiafy. This, however, 1s the subject of a later chapter.

From all that has been sald here, it is apparent that for Sohlegel the poetic world must be manifested in definite forms. The 1dea of genre 1s, in fact, olose to his 1dea of organia form, for within each genre every part and every exterior feature reflects an inner essence. When he Is defining the varlous Ilterary types, Schlegel continually uses the word "wesentI1ch." It 1s taken for granted that each genre does have an essential nature which is definable. Sometimes the definition is arrived at speculatively, but usually it is the result of the process whereby theory is produced by criticlem.

What 1s appropriate to a work within a ganre? Sohlegel always relates this question to the essentlal nature of the genre. What violates that nature 1s exoluded. All else 1s permitted, provided that it does not contradiot the higher olaimg of art. 
Oritical terminology takes on new meanings in dealing with varlous literary types. Dlalog is something different in the lyric, drama and epic. Poetic unity means something different in each case. Certain metric forms and poetlc devices are appropriate only for one genre. In any case, language down to 1ts minute details Is oolored by the genre for which it is used.

For the most pert Sohlegel develops his theories from actual oritical examinations of literary woriks. Once a genre is defined, however, Schlegel feels qualified to oritiolze a fallure to fulfill 1ts demands. He critiolzes Furlpides for the degeneration of tragedy at his hands. In the case of the epic, the whole essay on Hexmann und Dorothee is essentially an attempt to show how well Goethe was able to write a olassical epio in modern times. St1ll, as we will see in dealing w1th romantiolsm, schlagel 1s far from holding that the genres are fixed for all time. New ages require new genres. These too can be defined after examination, and the aucess of individual poets can In turn be judged by the degree to whioh their works reflect the mood of the genre as this 1s determined in the great works which are 1ts models. 
OHAPTHR IX

\section{IITIERARY HISTORY}

We have already touched on two aspeots of history in Schlegel's poetios. One 1s the 1dea of natural history or speoulative history of poetic origins. Schlegel's point of view here 18 that by explaining a thing's origing one explains what it 18, or what it should be (SW, VII, 107). It was remarked before that such speculative history was a favorite occupation of Schlegel's day, and he himself justifies it on one occasion as a popular form for speculative poetics. As history, such speoulations are of Iittle value. The possibilities for sentimental error are enormous. StIII, Schlegel can properly maintain that auch "history" is a fitting form for expressing speculations about the nature of Poesie.

The other aspect of history whioh has been touched on 1s history in a more conventional sense: the record of veriflable events, including artiotlo events, of the part. Schlegel's view of history in this sense must now be examined further.

In the Berlin Irectures (I, II-12) SchlegeI points out that history as a mere chronicle of events is meaningless. Writing history requires a cholce of the events whioh w1ll be recorded in 1t. Schlegel adopts the 1dealist view of history. The 1dee which governs the cholce of events to 
go into any written history is properly that of mankind's progress toward absolute goals. All history is "Bildungsgesohichte der Menschhelt zu dem was fur sloh $Z_{\text {weck }}$ an sich 1st, dem sittlich guten, dem wahren und schönen" (BerIin, I, 13). The influence of Schelling is evident here, as it is in Schlegel's 1dentification of the goals of history and philosophical theory:

So wie die Philosophle eine Geschichte des innern Menschen, so 1st die Geschichte eine Philosophie des gesamten Menschengesohleahts. Fs 1st dieselbe Frolution des mensohlichen Geistes, welche der Philosoph in der urspritngliohsten Handlung desselben als eins und untheilber begriffen aufoucht und ihre Gesetze darlegt, und die der Historiker von Zeltbedingungen abhëngig und in einem unendlichen Progre realisirt, vorstellt. (Berlin, I, 14)

This thought is applicable to art history. Furthermore, art theory cannot be carried out in a vacuum, but must be constantly referred to realities which history brings forward for 1ts consideration.

Sohlegel conglders next how we can reconcile the 1dea of progress with the perfection we demand of a work of art. An artist works under the limitations of his time, gays Schlegel. A work of art does not have to achleve an absolute perfeotion, only the higheat perfection posalble under the clroumstances. In this sense a work can be both perfect and part of the chain of progress (Berlin, I, 17). To reckon with genius, Schlegel adds that art works are always obfect1vely necessary but subjectively accidental. The genlus of mankind 1. the source of all Poegie, and the individual in whioh it is manifested is 
a historioal accident.

Art history is not bound to chronological time to the same degree that politioal hiatory 1a. Artiatic affinities mag stretch across millenia. Goathe's Hermann und Dorothea, for example, has to be considered alongside the Homeric epic (Berlin, I, 20).

The writing of art hiatory is made difficult by the lack of suffiolent examples in many perlods. Furthermore, since genius acts, at least in part, unconsolously, the words of the artiat themselves cannot always be belleved. Art history 1a also difficult because of the objects it deals with. It should be, as Schlegel puts 1t, a "Poesle In der zweyten Potenz" (Berlin, I, 20).

The relationship of history to oritiolem has been congldered previously. It should be added here that $\cdots$ Sohlegel stresses the relevance of history to art. Not just art history, but also history in general must be part of the critic's store of knowledge. To those who maintain that a work of art is a free invention of an individual artiat, Sohlegel replies that it 1s, nevertheless, true that the artist's environment and education influence what goes into the work (Berlin, III, 9-10). These influences on the artist include not only the spirit of his own age but also the whole hlstory of art before his time. And since matter and form are mutually determinative, we may say that the whole work is profoundly influenoed by 
141.

the age in which it 18 written. Frerything relevant must be discovered and related to the work. This 1s the task of the literary historian.

This brlef survey of Sohlegel's 1deas on history has been included as an introduotion to the following chapter on the distinotion of classic and romantic. It should be clear that Sohlegel has a deep sense of the algalficance of history for man and of 1ts relevance to I1terature and art in ganeral. National ilteratures can only be understood when the nations themeelves are understood. Purthermore, the literatures of great historioal epochs must differ just as profoundly as the epochs themselves. The two great epochs of western history are the ancient and modern and out of these come two strikingly different literary types. 


\section{OHAPTER $\mathrm{X}$}

\section{OIASSIO AND ROMANTIO}

Wherever Schlegel uses the term "romantisoh," it describes artistic works from the middle ages to his own times. He thought of his own oircle of literary friends as being more romentic than classic in spirit, but Schlegel never defines a programmatic movement with this term. Friedrlch Schlegel's tendencles to do this are ignored in August Wilhelm's published writings. He seems to follow Friedrich's definitions of "roment1c" as an zesthetio and historical category. It should be remembered, moreover, that the term was invented by neither of the Schlegels and was, in fact, employed to describe many of the I1terary events for which they used it long before there was a Romant10 movement. There 1s very little in Schlegel's works about Romant1o1sm, but there 1s a great deal about the nature of "romant1sohe Poesie.".

Sahlegel 1s aware of the origins of the term "romantisoh" in "romanos" in its Iingulstic sense and 1ts use to describe a speoifio I1terary genre. Romanoe is the adjective desoribing the languages ariaing from the mixture of Iratin with the dialeats from the north. Whence, Sohlegel tells us in the Berlin Ieotures (Berlin, III, 17), poems written in thege languages were called Romane, and from this comes the adjective "romantio.". The word suggests a furing 
of old German oultural elements with the late chrigtianIzed Roman. Presently we will see that one of romantic pootry"s traits 1s 1ts mixing of contrasting eloments. Sahlegel observes, in connection with his etymologizing on romantisoh, that modern clvilization is itself a mixture of northern traits and fragments of antiquity, whereas anclent civilization was more nearly unifled (SW, V. 9-10).

For Schlegel there are only two great historioal epochs in western Frarope, the ancient and the modern. The dividing line between the two is indistinct, but modern seems to begin in the middle ages with the firgt great cultural products of the fugion of Teutonic and BomanOhriatian in chivalry. With certain qualifications to be disoussed shortly, romantic and modern are equivalent terms and in the Berlin Lecturea Schlegel remarks that the romantic has its foundations in the chivalric ages

Dle altere romantische Poesle schrelbt sich aus diesem Zoitraume her, und die spätere lat wahrlich nioht dadurch romantisoh, daß sie in die neus zeit fâlit, sondern vielmehr, well sio sloh an die Gesinnung der ritterlichen Ze1t snsohließt, und oin Nachklang joner mâchtigen Naturlaute 1st. (BerIIn, III, II-12)

Schlegel sees the Greeks' highest achlevement in a refined and ennobled sensuality. After the golden age of Greek art there 1s a splritual deoadence which 1s overcome by the Ohriatian religion and by Germania vigor. The two come together to produce chivalry. The first romentic poetry is in the form of Neturpoesie, the 
chivalric mythology.

Sohlegel is at pains to maintain that the peouliarly modern has as great a claim to art as does the clasglc. In the Vienna Iectures he points out that Gothle architecture is a complete and finished system. A cathedral is to a Greek temple a Shake speare is to Sophoclea (SW, V, 11). In the Berlin Lectures he says the romantic is art because 1t is a unified purposeful whole (Berlin, III, 8). He speaks of a Romantic Sohool of poetry in the south (BarIin, III, 18). Iater we will consider how prose was raised by the moderns to the level of romantic art.

Before going on to a more precise charaoterization of the romantio, it should be noted that not everything modern 1s romantio. Schlegel's discussion of the subjeat always includes a defense of the romantic against neo-0laga1c1sm which would deny that the romantio 1s art. This modern classlolem 1s usually considered to be empty and artlese. In the Vienna Lectures Schlegel divides the whole history of drama into the ancients, their modern Imitators and those moderns who pursued an original course (SW, V, 18). The possibility of a genuine neo-classiclam 1s not completely excluded (we should remember his admiration and praise for Hermann und Dorothea) but greater value is placed on the genuinely modern, the romantic. of course Sohlegel recognizes, as he must, that the history of modern Ilterature is largely one of imitation of the 
ancients. In the Berlin Lectures he remarks that there 1s practioally no romantic art in Germany unt1l the recent rebirth of feeling for genuine poetry and the contemporary atriving for a new style of romantic art (Berlin, III, 20-2I).

Sohlegel characterizes romentio art above all by contrasting it to olassic art. We have already touched on the historical dichotomy ancient-modern. We will now deal with several more such contrasting 1deas with the aim of defining the romantic. First, however, a word should be aald about Schlegel's orlginality in these matters. Schlegel himself points out in the Vienna Lectures ( SW, V, 10) that others before him sought to define by contrast the difference between ancient and modern. He mentions Rousseau and Hemsterhuis. He should have mentioned Schiller as well, although it should be remembered that in 1794, before Schiller apoke of naiv and sentimental1soh, Friedrich Sohlegel wa. writing of die sahöne Poegle and die interesgante Poes1e, oategorles which are really the classic and romantic in Friedrich's early formulation of the contrast. ${ }^{I}$ In the same year, at a time when Friedrich still held the classic to be the superior form of art, he mentions in a letter to Auguat

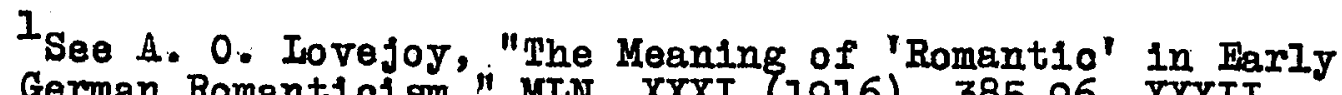
German Romant1 101 बm," NIN, XXXI (1916), 385-96, XXXII (1917), 65-77, espec1011y pp.66-67. Reprinted in his Fegers in the Historr of Idess (Baitimore, 1948) pp.183- 
146.

Wilhelm the latter's plan to write a history of romantio poetry. ${ }^{2}$ The losa of August Wilhelm's letters to Friedrich, however, makes the priority of their thoughts aiffiault to determine. Unfortunately for August Wilhelm's claim to ariginality, the thoughts which follow were not included in his 1798 leatures and by the time of the BerIin and Vienna lectures Frledrloh had covered much of the same ground, though less thoroughly, in published writings, notably the "Gespräch uber die Poesie" (1799).

The most striking of the distinctions between olassic and modern is that of plastio and pleturesque, a contrast suggested by Hemsterhuls but elaborated at some length by Schlegel. It is touched on in the firgt series of Berlin Iectures where he discusses rhyme. He suggests that rhyme is essentlally romantic and in contrast to the plastic isolation of classic poetic lines. This thought. 1s carrled much further in the Vienne Irectures. The spirit of ancient poetry is plastic, that of romantio picturesque. In soulpture our attention is alrected to an isolated group, whereas painting presents the surroundings of its main objecta. Painting includea minor details and gives a perspective into an unlimited background (SW, VI, 32-33). Oontrasting classic and romantio drama, Schlegel observes that the latter does not separate 2 Priedrioh Schlegels Briefo an Beinen Bruder August W11halm, ed. Oskar WalzeI TBerlin, 18907, p.170. 
1ts action from life but rather embraces all of life. Its objects seem to be accidentally brought together, jet the romantic drama satisfies better the unconselous demands of Phantesie, and it gives a soul to 1ts objects:

[Fs befrledigt] die unbewaßten Forderungen der Phantrsie, vertieft uns in Betrachtungen uber die unausspreohliche Bedeutung des durch Anordnung, Nhe und Ferne, Kolorit und Beleuchtung harmon 1sch:gewordnen Soheines, und leiht gleichsam der Ausgicht eine Seele. (SW, VI, 163)

We will see that the expresalve capabilities of romentic poetry are boundless.

Schlegel also formulates the contrast 1dealischmystisch, whereby he tries to explain the classic drama's closer approach to unity of place and time. In the clasalc drama space and time are subjected to the activity of the mind. In the romantic they are honored as incomprehensible essences, supernatural powers in which there is something divine (SW, VI, 33).

Schlegel points out a further contrast which is reflected in the Ohristian element in the modern. The Greeks a spired to the perfection of human powers on this earth. The Ohristian view is that the paradise of man's highest achievement is forever lost and can only be sought after in this world. It can never be regained by purely human powers. For Ohristian man, says Schlegel, "die Anschauung des Unendlichen.hat das Endliche vernichtet" (SW, V, 16). Ohristlanity leaves man with the melancholy feeling that nothing on this earth can fully 
satiefy his desires. Hence Schlegel's observation that the poetry of the anolents was the poetry of enjoyment, while the romantic is the poetry of desire. Of course there are elements of both points of view in all literature but, seys Schlegel, the feeling of the moderns is on the whole more inward, their Phantasie more incorporeal and their thoughts more contemplative ( $\mathrm{SW}, \mathrm{V}, 16$ ).

Related to this is the fact that the Greaks sought a natural harmonlous working of all human powers. The moderns, however, are always conscious of an internal discord between body and mind. Romantic poetry tries to resolve this discord:

Die sinnliohen Elndrioke sollen durch inr geheimnisvolles Btindnis mit höheren Gefthlon gleichsam gehelligt werden, der Gelst hingegen will seine Ahndungen oder unnennbaren Anschauungen vom Unendliohen in der sinnlichen Frscheinung sinnbildlich nlederlegen. (SW, V, 17)

This contrast seems to be reflected in the unconsclous unity of matter and form in Greek art, whereas romantic art reveals a struggle between the two. The Greeks accomplished their goals with perfection, whereas the romantic strives after the infinite only by approximation. Schlegel says romantic art is in denger of being undervalued because of the resulting appearance of imperfeotion (SW, V, 17). Anolent art, seys Schlegel, separated things which were not similar. Romantic art delights in mixtures, the more paradoxical the better. All opposites, nature and 
art, poetry and prose, serlousness and fest, memory and antiolpation, splrituality and sensuality, the earthly and the divine, life and death, are all blended together (SW, VI, 161). A mixture of diverse poetic elements is characteristic of the romantic genres. In the Berlin Lectures where this point is made, Schlegel goes on to say that those who overlook the beautles of romantle art have no sense for chaos, which 1s, from a higher point of view, the nature of the universe. In a fragmentary note, reminding us of Friedrioh Schlegel's progressive Universalpoesie, he remarks that the striving for the infinite in romantic poetry 1s expressed not only in individual works but also in the whole course of art. Romantic poetry 1s "Gränzenlose Progressiv1tät" (Berlin, I, 357).

In the Vienna Ieotures, too, Schlegel says that anolent art is bound to order, while romantic art loves cheos:

[Die gesamte alte Poesle und Kunst 1st] glelohsam ein rhythmischer Nomos, eine harmonisohe Verkindigung der auf Immer festgestellten Gesetzgebung einer sohön geordneten und die ewigen Urbilder der Dinge in sioh absplegelnden Welt. Die romantisohe hingegen 1st der Ausảruok des gehelmen Zuges zu dem Immerfort nech neuen und wundervollen Geburten ringenden Chaos, welches unter der geordneten Sohopfung, ja in ihrem Schooße sloh verbirgt.... ( $\mathrm{SW}, \mathrm{VI}, 161$ )

As a result, anolent art tends to produce perfected works of art, but the romantio comes closer to expressing the secrets of the universe.

We have consldered these diohotomles: plastlo- 
plcturesque, 1deal-mystic, enjoyment-desire, hermonydiscord, unity-struggle to unite, perfection-approximation, distinction-mixture, law-ohaos. Oonsidering that the olassic and romantic are so profoundly different, it is hardif surpriaing that the poetic genres for each also differ in a fundamental way. As a preliminary to the study of these genres, we must consider one more dichotomy which leads direotly to the subjeat: poetry-prose.

An important characteristic of romantic literature is its use of prose. Almost without exception, what was written in prose in ancient times was by nature prosalc. The anclents often used verse for prosalc purposes but rarely tried to achieve a poetic ond in prose. The beginning of romantic Poegle in prose comes with Boccaccio. The superiority of his prose over that of his predecessors and contemporaries is explained in the Berlin Irectures. There Sohlegel contrasts Boccecclo's prose to that of the early French chivalric novels which cannot claim to be poetic representations by means of prose but rather are mere prosa1c reports (Berlin, III, 239). Bocoscolo was the firat whose prose had a style. We recall that for Schlegel thls means creation limited by an art princlple. He goes on to say that prose before Boocacclo was not a product of a pure art drive. True romentic prose, moreover, 18 "wahrhaft darstellende und beredte" (Berlin, III, 240). Sahlegel also oalls it "die nenere Poegle." 
The boundaries of the romantic genres are somewhat vague. The lyric appears in some form within all the other genres. By Sohlegel"s definition, history (in a special sense) is the subject of the novelle, but it is also to a degree the subject of the novel and of some plajs. Petrarc's collected lyrios are spoken of as a Iyric novel (Berlin, III, 204). The romantic drame often uses material sultable for, or even adapted from, the novella. Furthermore, the novel is the central romant10 genre, and Schlegel tells us that the whole form of the drama must be judged according to 1ts prinaiples (Berlin, III, 24I).

The romantic lyric, Ilke the classic, deals with emotions. But feelings differ in the romantic age, and the Iyric reflects man's contemplation of infinity, rhapsodic trangformation of life through love, the charm of life's riddles and eternal secrets. It also deals with many more sides of Iife than did the olasgle lyric. Friendship, the inclination to Poesie, patriotism, political intereats, even divine anger find a place (Berlin, III, 205). To express these things, new poetic meang were required. Rhyme has already been mentioned. It involves memory and expectation, and so connects parts of the poem together, at the same time separating the joined parta from other eloments in the poem. Rhyme aids in expressing the romantic love of the seemingly paradoxical 
but highly meaningful connections of things. New verse forms arlse: canzone, bellad, sonnet. Fepecially in the sonnet are the connecting and dividing functions of rhyme used in the most complex and meaningful way. The romantic lyric types are the subjeot of long technioal alscussions by Schlegel.

One of the peculiarities of modern poetry is the fact that it makes use of history as subject matter. According to Sahlegel, the novella is the genre which always has as Its subject matters from history which, although they are not 1mportant enough to get into hletory books, are nevertheless interesting (Berlin, III, 242). Since 1ts subject material is prosaic reality, its essential form is prose. The writer's model 1s the soalel storyteller. St11l, the novella rises above nature's model. It can have a.1 sorts of moods, from traglc to trivial, but it must be at home in the real world. The novella's action 1s quick and to the point, wherein 1t stands in contrast to the gradual prograss and slow changes which take place in the novel.

Sohlegel doer not epeak of romentic tragedy and comedy, but rather of romant1o drama (Sohaugpiel). The main point of difference 11es in the ancients limited purpose and means as contrasted to the moderns' universality and their mixture of poetio means. Shakespeare 1s the prime example of the mixture of tragic and comic elements 
153.

within a single play. In the Jena Leotures Schlegel lists the characterlstios of Shakespeare's drame which are those of the romantic drama in general (1798, pp.217-19). As in the case of the novel, the romantio drama is a mixed genre which combines tragedy and comedy, verse and prose. It utilizes contrasts of metter and form. Romantic drame often presents problems for whlch there can be no solutions. The characters individually determine their fate. The romantic drame can use themes from history. The techniques and mechanies of the drama are more lax than in ancient tragedy. There is a mixture of styles and verse forms within the drama. It strives for manifoldness and universality. Far from being evidences of artiatic degeneration, these qualities in romantie drama are true poet1o beauties.

In the Jena Lectures Schlegel remarks that the novel Is a collection and mixture of characters brought together w1thout a definite purpose, and he adds that 1t should have no didactic purpose (1798, p.215). He orit1cizes the realiatic and sentimental novel. In the Berlin Lectures he expresses the opinion that there is nothing worthy of the name in the time between Don Quixote and Wilhelm Meister (Berlin, III, 241). In his praise of the latter work in the Jena Leoturea Schlegel Indicates what the novel can be. It is proseic in many respects, but it forms a symphonic whole. The novel contains lyric and 
dramatic admixtures. Its prose is poeticized by rhythm and poetlc detail. The novel deals with all of Iife and its smallest detail is meaningful and symbolic. In contrast to the epic, it is subjective (1798, p.216).

In the Berlin Lectures Schlegel remarks that the essence of the novel is the comprehension of the poetic In Iife. It is a sort of biography (Berlin, III, 204). Commenting on the late Roman prose works, Schlegel says,

Sie sind . . meistens schlecht oder gar abgesohmackt, statt daß die Neueren Mittel gefunden haben, solchen Compositionen eine Welt von innern Bezlehungen zu geben und die feinste Figenthưmlichke1t und gebildetste tbersicht der menschlichen Dinge darin auszuspreohen. (BerIin, III, 240)

In general, the novel is the most romantic of the genres, for it embraces all of human Iffe and, in doing so, all the paradoxes, dichotomies and approaches to the world's intimate mysteries which are all oharacteristio of romantlache Poesle. Schlegel oalls the novel the genre which represents the whole of romantic poetry (Berlin, III, 241).

In a discussion of the romantic genres, Dante deserves special mention. Schlegel praises the Divine Comedy as an allegorical representation of the universe (Berlin, III, 193). It 1s characteristicaliy romantic in 1ts glimpses of infinity and in 1ts universality. The Divine Comedy combines theology, philosophy, mythology and even natural solence to achieve 1ts goal. What interests us here, however, is the fact that Schlegel felt there is nothing 
155.

In all of I1terature which is quite comparable to it. The Dirine Oomedy belongs to no genre and 1s, as Sohlegel calls 1t, an absolute individuality (Berlin, III, 238). Although he does not develop the thought, it seems that his earlier statement, that what does not belong to a species of organization is monstrous, must be modified in the case of romantic art.

The oncluding chapter of this study will go bejond the romantic art considered here, which 1s essentlally that of Petrarc, Bocceccio, Dante, Cervantes, Dalderon and Shakespeare. There we will consider soholarly opintion on Schlegel's theorles and attempt to characterize the role of the theorles in the history of the German Romantic morement. 
OHAPTER XI

OONOLUSION

Scholarly treatment of Auguat W1lhelm Schlegel ranges upward from the extremely critical portrait of a small minded man by R1cerda Huch ${ }^{1}$ to extremes of praise by uncritical admirers. The accepted viow of Schlegel $1 \mathrm{~g}$, however, more nearly balanced. Schlegel is considered to be a failure as a poet, a genius at translation, a master of the art of literary oritiolam, and, in both his critiolsm and his theoretical writings, a man of little originality but of great popularity and moderate influence in his own day. A number of scholarly evaluations of Schlegel's theoretical writings must be viewed here in more detall.

The usual beginning of any discussion of Sohlegel is an apology for his shortoomings. Walter Sohirmer begins his lectures on Schlegel with the observation, "1hm fehlte die Tiefe und Orlginalität des Denkens, dio Maplosigke1t des Frlebens und die vôllige dichterisohe Hingabe, die Glück und Fluch seiner romantischen M1tkämpfer waren."2 Schirmer goes on to maintain that Schlegel's faults were

IDle Romantik, 5. Auf1. (Ie1pzig, 1913), I, 1-II. 2"August Wilhelm Schlegel, Dre1 Vorträge gehalten an der Univergität Iondon, November, 1938," in his Kleine Sahriften (Tubingen, 1950), p.153. 
what allowed him to play his influential role as romantio theorist and mediator:

We1l or felnstes diohterisches Finlen besap ohne die Gabe sohöpferisoher Aussprache konnte und mupte or das System einer umwälzend neuen Kunstkritik aufstellen, die b1s heute europä1soher Besitz geblieben ist. Und weil or die kuhnen Gedanken und poet1schen Träume seiner romantischon Genoßen herabebnete und glelchsam klassisch rationalisierte, konnte er ihnon das Ohr der Welt verschaffen.

Schlegel's sobrlety and his lack of creative abllity thus, according to Schirmer, sulted him for the role of a romant1c propagandist. Schlrmer sees Schlegel's crit1cism as the most important means for his making romantic 1deas popular. Schlegel's role in history may not be as enviable as that of some of his contemporaries. But, says Schirmer, Schlegel's Importance is profound. It Iles in his ralsing romantio oritiolom above mere speculation, in tพо พละร:

1) Fr allein unter den Romantikern entgeht der Gefahr einer in anschauungslose Abstraktion sich verlierenden Kunsttheorle und Isthetik. Wodurch? Durch die Fingliederung der Theorie in die historlsohe Darsteliung . . - 2) Fr allein unter den Romant1kern entgeht der Gefahr bel dieser Iehre von dem nechfthlenden Frkennen jeglich Wertung uber Bord zu werfen, allverstehend aber eben darum direktions10s auf dem uferlosen Geblet der Dichtung umherzutroiben. Wodurch? Durch Gligderung in einen Rahmen, in ein Sygtem, Wenn man Fil1.4

It should be remarked that Sohirmer's statements imply

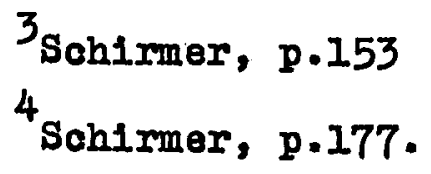


that the theories are the servants of Schlegel's critic1sm. To a large extent th1s is true and we have seen that sohlegel sees the two as inseparable. The conneotion of criticlam and theory is noteworthy in that it lends support to the olaim that Schlegel was a popularizer. Oritiol sm has a far wider contemporary audience than do aesthet1c systems. On the other hand, if crit1cism is to carry conviction, it must be supported by a rational foundation, as Schlegel himself maintains.

Fill Stalger has stated more strongly the greater importance of Schlegel's orlticlem as compared to his theories. Stalger calls Schlegel "ein durohaus unphilosophlscher Kopf" and goes on to explain,

er bedient sich der philosophischen Brrungenschaften nur, um einen Text zu charakterlsieren, unbeklimmert derum, ob seine Begriffe wirklioh zusammenstimmen oder unvereinbar und verschiedenartigater Herkunft sind. Wer seine Sohriften euf ihren philosophlschen Wert hin untergucht, wird finden, or habe es mit einem vagen Frclektiker zu tun.5

With certain qualifications, Staiger nevertheless feels that Schlegel'g rather shaky poetic theorizing was no hindrance to worthwhile and influential orlticlem. Another scholar who hes dwelled on the importance of Sohlegel's orlticism is Rene Wellek. H1s conclusions have been considered at a number of points in this study. A summary of his vlews is required here. Wellek, like From Stalger's edition of Sohlegel's Xritisohe Sohriften (ztrich, 1962), p.24. 
159.

Schirmer, considers Schlegel's shortcomings as a romantic poet to be advantages for the romantic oritic. In perticuler, Schlegel's critical virtues are sobrlety, conoreteness and attention to relevant detail. Since Wellek's subject 1s oriticlam rather than theory alone, he is not conoerned with Sohlegel's writings as a system of poetics. Wellek Is more charitable than Stalger Inasmuch as he does not describe Schlegel as completely unphilosophical or as a mere eclectlc. But the outlook of both Staiger and Wellek is essentially the same: Schlegel's theories need not be examined as a philosophical system but rather only as the substantiation of his literary judgments.

In his oriticiom of Schlegel Stalger has, it appears, separated oriticism and theory and concluded that the latter was done rather poorly. Schirmer and Wellek come closer to agreeing with Schlegel's own dictum that the two endeavors are inseparable. Oriticism produces theory and theory substantiates criticism. One Important study of Schlegel, however, conslders the merits of Sohlegel's theoretioal system as such. This is Rudolf Haym's Die romantische Sohule. 6

Haym examines Schlegel's early orltical works in great deta1l. He points out Schlegel's dependence on Kant, Schiller and Goethe. Schlegel is portrayed, in lla pre-

63. Aufl., ed. Oskar Walzel (Berlin, 1914). 
160.

Jena period, as a man of educated taste but with little originality except, perheps, in his theorles of translation. Haym sums up Schlegel's early critical works with the statement, "fitrwahr, einen besseren Apostel und Dolmetscher konnte sich der Goethe-Schillersche Klass1zismus nicht wînschen! ${ }^{7}$ Schlegel's turn toward romant1cism came only after his acquaintance with Tleck and his closer relationship to Friedrich after 1796. Thereafter Haym sees Schlegel as the practical representative of the romantic point of view:

Den eigentlich praktischen Sinn, den Sinn fur Varwaltung und Regierung, ftur Krieg- und Geschëftsfuhrung, fur Verhandiung und Repräsentation hatte unter ail den verbindeten doch nur August Wilhelm Schlegel. Er war das organlsatorische, das durchaus formale Talent des ganzen Kreises. Wohl fehlte inm die Frfindsamke1t des Bruders, aber was inm in dieser Beziehung abging, ergetzte er durch Fleiß, Gesohmack und Ordnungssinn.

Schlegel is here portrayed as something of a public relations expert for the Romantics. The means he used were mentioned earlier: essays, reviews, criticism, satire and, above all, his lectures. Schlegel's lectures are discussed by Haym under the heading "Vorlesungen als Mittel der romant1schen Propaganda."

The following pasage will serve as a summary of Haym's mixed praise and criticism of Schlegel's lectures in Jena and Berlin:

$7_{\text {Haym, p.181. }}$

$8_{\text {Haym, p.762. }}$ 
Durch [die Vorlesungen] tritt $W$. Schlegel in diesem letzten Stadium der Bntstehungageschichte der Romantischen Schule entschieden vor all den tibrigen Genossen in den Vordergrund. Sie erst sind es, die uns, ganz anders noch als das schellingsche System und ganz anders als das Gespräch ther die Poesle, einen vollen Uberblick uber Inhalt und Umfang der Beatrebungen der neuen Schule gewëhren. Frat hler, be1 dem Apostel der Romentik, haben wir die Romantik ganz und ala ein Ganzes. In der erster IInie . . erscheint er als der Ausfuhrer und Dolmetscher der Gedanken seines Bruders. Zuglelch Indes als der geschiokteste Ordner und systematiker.9

On the one hand we find in Haym a thorough argument that there is very little that is original in Schlegel's poetics. On the other hand, Heym goes beyond the view that Schlegel's" theories are subservient to his criticlem. Haym speaks of the lectures as a system.

The views of the four scholars discussed above present the main problems in an evaluation of Schlegel's poetic theories. These are: 1) the relative importance of Schlegel's criticlem and his theorles; 2) the question of Schlegel's orlginality and 1 ts bearing on his claim to be read; 3) Schlegel's position in the Romentic movement. It should be stressed onoe more that the union of h1story, theory and criticism recommended by schlegel in theory is fulfilled in practice. Neither theory nor criticism is subjugated to the other. It might be argued that the Vlenna Iectures are Schlegel's most influential work, but we an hardly call it a purely theoretical work. H1story, theory and oriticl $\mathrm{sm}$ are interdependent a spects $9_{\text {Haym, p.829. }}$ 
of the lectures and cannot be wholly separated. Haym himself suggests that this is true of the Berlin Lectures when he says, "Kritik und Polemik [1st] die Seele des Ganzen."10 And we must remember that two of the three serles of lectures delivered in Berlin deal with the history of classic and romantic literature. On the other hand, Sohlegel's criticlsm is based on history and is presented within a theoretical framework. In short, if we speak of a theoretical system by Sohlegel, it must be extracted from works whose subjects are broader than theory alone. Both the Influence and the intrinsic merit of Schlegel's criticiem and his theorles must be considered together.

The matter of Sohlegel's originality was dealt with in the introduction to this study. It must be admitted that the majority of Schlegel's statements find parallels in the works of his contemporaries and immediate predecessors. It was suggested earlier that Schlegel's accomplishment was that of the soholar rather than the philosophical innovator. This is essentialiy the view of Haym when he calls Schlegel the systematizer of the Romantic sohool. Schlegel's historical importanoe lies in his closeness to the literary movement of whose 1deas he was the systematizer.

Haym's evaluation of Schlagel is typical of scholarly ${ }^{10}{ }_{\text {Haym, }}$ p. 830. 
opinion on his theories. Schlegel's originality, it is argued, lies not in the content but in the formal qualities of his works. Schlegel's Virtues, we recall Haym saying, are industry, taste and a sense of order. The main virtue of his theories is that they are systematic. To this should be added another quality whlch has been stressed often in this study, his union of history, theoxy and criticlom. Again the accomplishment is not so much a matter of original insight (although this is far from being entirely lacking) as of skillful and, we may say, original organization of relevant facts and theorles.

In stressing Sohlegel's systematizing role Haym becomes rather extravagant in his praise of Schlegel:

Schlegel tuberhaupt war der erste der, nach dem Allerhand von halbwahren und wunderl1chen, Poesle und Kunst betreffenden Finfëllen, wie sein Bruder ale ausitreute, und nach dem einstwellen ganz im allgemeinen gebilebenen Unternehmen Schellings, die Kant-sohillersahen Gedanken in die form des transzendentalen Idealismus zu gießen, ein auf diesem Standpunkt gich aufbequendes wirkilches System der Iathetik voliendete. II

There is a good deal of truth in this statement, espeaially in 1ts gtressing August Wilhelm's organized approach as compared to that of his brother. Nevertheless, Haym's praise must be tempered with a bit of Stalger's akepticism about Sohlegel's philosophical talents. Schlegel's theorles hardly form a system of aesthetics. Although he draws philosophical support from many sources, he has not con$1_{\mathrm{Ha}, \mathrm{ym}}, \mathrm{p} .837$. 
structed a philosophical system. His theorles are proved not by their irrefutable logloal coherence but rather by their pragmatic vaIue in explaining literary facts. Again 1t should be repeated that Schlegel's theories are best characterized by their union with oriticlsm and history.

The relationship of Schiegel to the Romantic movement has been touched on already. Schlegel, it has been suggested, was the ofrole's systematizer and 1ts popular1zer. He was also, as Körner has shown in his Die Botsohaft der deutsohen Romantik an Furopa, the mediator between German Romantiolsm and the rest of Furope. With some qualifications concerning Sohlegel's systematizing, these roles are all characteristic of his theoretical labors. There is, however, some question as to the extent to which Schlegel is really a true representative of romantic poetics. There are many respects in wh1oh Schlegel's literary theories are romantic. H1s theory and criticism is to a large degree directed toward upholding the artistic claims of modern literature, espeoially of the romantische Poesle of the early modern period. Sohlegel's description of romantic poetry's qualities is typical. These qualit1es are, furthermore, considered to be properly those of I1terature after the Renalssance insofar as it 1s distinctively modern and not inspired by an anachronistic classicism. 
romantic. Poesie is not just literature. It is an intuition and revelation of the nature of things. Poesie reveals in plastic images the truths of transcondental philo sophy. It is a natural outgrowth of human nature. Poesle appears in non-resthetlc forms (Neturpoes1e) but 1t is also the highest artistic product of man's selfconsclous activity. The expressive capabilities of poesie are considered to be limitless.

There are many such romantic formulations by Schlegel. There are also a number of deviations from the poetlc theories of Schelling, Novalis and Fredrich Schlegel. The principal non-romantic tendencies in Schlegel's theorles must be noted.

First of all, it should be observed that Schlegel's descriptions of romantische Poosie refleot loss personal involvement than do the theoretical statements of Friedrioh Sohlegel and Novalis. The concept of romantic poetry remaing more a historical and cilical one. Romant1c poetry is something given by history which the critic must deal with. The concept is not broadened to include all Poesie as, for example, in Friedrich's statement, "Die romantische Dichtart lat die einzige, die mehr als Art und gleichsam die Dichtkunst selbst 1st; denn in einem gewlssen Sinn 1st oder soll alle Poesie romantisch sein. "12 $12_{\text {Rasch, p. } 39 .}$ 
At times Schlegel comes close to agreeing with this statement insofar as it is applied to the Iiterature of the future. But h1s own theoretical statements are usually based on a higher idea of Poeste wh1ch embraces both olassic and romantio. His theories of romantische Poesie are not, however, a program for the future but rather a basis for judging a literary type found in history. To a far greater extent than for his contemporaries, romantigiche Poesie for Schlegel means the writings of Dante, Petraro, Boccaccio, Oervantes, dalderon and Shakespeare.

H. A. Korff desoribes an important aspect of romantic literary theory with the formula "Relativierung des Werkes." By this he means the poet's rising above h1s works and, as he puts 1t, the "Frlösung der in dem Gegenstande gle1chsam verzauberten Poesie." 13 The "Relativierung des Werkes" may be an important part of the experience of the romantic poet but not so for Auguat Wilhelm Sohlegel, the romentic crit1o. Korff 18, of course, speaking of Friedrich Schlegel's theories of romantic 1rong. The subject is virtually unmentioned in August Wilhelm's writings. We have seen that his 1dea of Poesie does go far beyond the nalve 1dea of "poems", that 1s, specific 11terary works. For the critic and literary technician, however, works are not "relat1viert." Schlegel views works of both classlo and romentic 3. durchges. Auf1. (Leipzig, 1959), III, 268. 
art not as an artist conscious of the irony of oasting a maglcal Poesie into mere words, but as a critic who must explain the content and form of given verbal structures. Another departure from romentic poetics is Schlegel's fallure to deal with what Korff calls Its "Marchenldeal" as 1t was formulated, above all, by Noval1s. Korff sees the philosophic justification for the romantic preocoupation with dream and falry tale in transcendental philosophy. He contrasts Schiller and the romantios in their appropriations of transcendentalism:

Durch Schiller kam in die deutsche Dichtung erst die ethische Aspekt der Transzendentalphilosophie: der gewaltige Kampf von Natur und Gelat. Von der größten Thtdeokung der Transzendentalphilosophie dagegen, der Untersaheidung der belden Welten, oder anders gesprochen von der Verwandlung der natürlichen Welt in elne rätselhafte $\mathrm{Frschelnungswelt,} \mathrm{splrt} \mathrm{man}$ in Schillers Dichtung nichts. Von diesem "romantischen" Mot1ve ble1bt sie noch vôllig unberuhrt. Die romentische Dichtung entspringt gerade diesem Motive der Transzendentalphilo sophie. Ja sie 1at nach ihrem letzten Wesen nichts angeres als die diohterische Frucht der neuen Metaphysik. 14

Sometimes Schlegel too speaks of the world as a rlddle, but Poesie is its solution, not just a further riddle. It is true that Sohlegel speaks of romantic poetry as an approximation toward expressing the infincte. But when he speaks of actual Iiterary works his general statements on the nature of poetry come closer to the 1deals of German Olagsic1sm. The struggle between Natur and Gelat must be resolved. Oontent and form become one united whole. Mran14 Korff, III, 280. 
scendental philosophy, for Schlegel, points not to the chaotic nature of the world so much as to the orderliness of man's experience of 1t. And this order is revealed, above all, in the highest literary art. Again it seems evident that Novalis and Friedrich Schlegel speak of Poegie as a personal experlence, whereas August Wilhelm Sohlegel speaks from his characteristic historloal-theoreticaloritical standpoint. Poesie is not a personal problem of adequately expressing a puzzling world. Rather it 1s, in most of h1s statements, something already accomplished: artistic works appearing within a historical framework and there to be evaluated oritically within a theoretical system adequate to them.

Another departure from romantic poetios is in Schlegel's refusal to adopt any extreme doctrine of aesthet1cism. Frledrlch Schlegel's famous Athenaeum fragment on romantische Poesie states "[Die romantische Dichtart] allein 1st unendlich, wie sie allein frel 1st und das als ihr erstes Gesetz anerkennt, daß die Willkur des Dichters kein Gesetz uber sich le1de."15 For August Wilhelm Schlegel, however, aestheticism remains more problematical. He follows Kant and Schiller in their freeing art from all external goals. But he does not go far beyond the position that art requires a willful submission to aesthetic laws. 
Art, including romantic art, must be beautiful and this implies that it must be meaningfur. Art never degenerates Into riddles whose meanings are virtually the exclusive property of a completely autonomous poet.

This discussion of Schlegel's romentiolsm began by pointing out that his point of view is in fact largely romantic. The subsequent qualifications are not intended to deny Schlegel's romantic inclinations. Rather the purpose was to suggest that the critic's theories do not always reach the extremes of those of the poets. Schlegel cannot be called merely the systematizer of views formulated by his more talented contemporaries.

There are romantic elements in Schlegel's theorles but they hardis constitute a systematization of romantic aesthetic theory. The word "popularization" suits Schlegel's romantic theorlzing somewhat better. His lectures were popular and, in their printed form, widely read, as rofmer has demonstrated in some detali in the case of the VIenna Lectures. Insofar as Schlegel's works had a deeper influenoe, it was not as an aesthetic system. The only writer of major importance who was influenced by Schlegel was Ooleridge who borrowed a number of details from the Vienna Leotures. 16 Iater theorists pass over Sohlegel.

16 In particular, 0oleridge adopted Schlegel's oontrast of plastic and picturesque, the 1 dea of mechanical and organic form, Sohlegel's theorles on dramatic unity and the 1 dea of Naturpoesie and the foundation of poetry in basic human nature. In addition, Coler1dge borrowed much of Sohlegel's 
He is not mentioned in most historles of aesthetios. Neglect in such works 18, in spite of Haym's argument, not entirely unjust, for Sahlegel's works do not const1tute the romantic aesthetic system Haym sees in them. It is entirely appropriate that the most recent evaluation of Sohlegel's theories, that of Wellek, is in a work entitled A Hiatory of Moderm Oritiaism.

Although Sohlegel's theories are not a systemat1c romantic poetics, they are not lacking in coherence. The unifying themes are: 1) the relationship of Iiterature to primordial poetry in 1ts three forms, language, rhythm and myth; 2) the relationshlp of literature to the theory of language; 3) the relationship of Iiterature to the philosophy of Kant, Fichte and Schelling. In the case of Fiohte and Schelling this is done Iargely through the subject of language, which is both the mediator of consclousness and the medium of Poesle. 4) a number of recurrent related themes: poetry as a higher (potenzlerte) mode of expression; the connection of poetry and philosophical speculation; art as a flotional world; the essential nature of the poetic genres; the classical themes of the reconciliation of Natur and Geist and the harmony of

oritiolsm of Greek drama and of Shakespeare. Although Sohlegel' influenoe is clearly demonetrable, Coleridge denled 1t. See Phelan, Anna Auguata (Helmholz), The Indebtedness of Semuel Teylor Coleridge to August WIIhoIm Sohlegel (Mad1son, I907), especialiy pp.355-62 where her conciusions are summarlzed. See also Wellek, II, 154-59, on dolerldge and Sohlegel. 
matter and form in art; the attempt to justify the artiotic claims of romantic art; 5) finaliy, and most important, the unity of history, criticism and theory.

The unified approach to literature through history, criticlsm and theory remains the most important oharacteristic of Schlegel's writings. As admirable as this approach may be, it would seem that in 1t Iles part of the reason why Schlegel. 1s so little read today. The philosophically inclined reader of Schlegel's lectures will find them lacking in systematic plan and logical execution. The historian will find Schlegel's views antiquated in some respects and, perhaps, too theoretical. Those interested in Sohlegel's oriticism will be more likely to turn to the shorter works where theory is more in the background. This study, which has sought to clarify Schlegel's theorles by extracting them from the history and criticism, should properly end with the hope that the reader will examine the theorles in the works in which they appear. Sohlegel ${ }^{4}$ s poetic theorles gain in persuasion by their setting in their original historical and oritical context. The major interest in schlegel w1ll undoubtedly continue to be that of scholars of German Romanticism. Many of the problems he discusses, however, are still with us and his atatements on myth, symbolism, organic form, meaning in literature and, In general, the nature of the relationship of the flctlonal world of poetry to the real world around us are still relevant even when they are not completely sat1sfying. 
Hopefully the recent republication of Sohlegel's orltical works and the Berlin Lectures ${ }^{17}$ (in what professes to be a more popular than scholarly edition) will help Sahlegel regain the wider attention he deserves.

17 The edition mentioned here, that of Fdgar Iohner, is discussed in the bibllography which follows. 


\section{BIBIIOGRAPHY}

The following seleat blbllography includes only works whlch contain materlal relevant to this study. A few introduatory remarks are necessary. Schlegel is quoted from the Bocking edition of his works except when better editiona exist or the writings under consideration are not in Böcking. There is no really sat1sfactory scholarly edition of the Vienna Lectures. The edition of G. V. Amorett1 (Leipzig, 1923) is no improvement over Bôcking. Another useful edition of Sohlegel's critical writings should be mentioned: Kritische Sohriften, ed. Em11 Staiger (Zurich, 1962) in the ser1es Klassiker der Kritik. Since 1962 four volumes of Schlegel's writings have been published in the serles Sprache und Iiteratur In an edition by Fdgar Iohner: Kritisohe Schriften und Briefe (Stuttgart, 1962-65). These include the entire text of the Berlin Lectures and a selection of Schlegel's other orltical and theoretical writings. The selection, entitled Sprache und Poetik, is little Improved over Bo.cking and the edition of the Berlin Iectures is virtually a reprint of Minor's edition but without h1s critical introductions. The main virtue of Iohner's edition 1s 1ts accessibility. For this study the older standard editions seemed preferable. Friedrioh Sohlegel, however, 1s quoted from the recent edition, Kritische Sohriften, 
ed. Wolfdietrioh Ragoh, 2. Aufl. (Mrinchen, 1964).

Frledrloh Sohlegel's letters to August Wilhelm are contained in Friedrioh Sohlegela Briefe an selnen Bruder August Wilhelm, ed. Oskar Walzel (Berlin, 1890). August W1lhelm Schlegel's works and selected secondary materials are 11ated below.

I. Schlegel's works and letters.

Sämmtliahe Werke, ed. Eduard Böoking. 12 vols. Leipzig, $1846-47$.

Vorlesungen iber phllosaphlsche Kunstlehre, ed. Jakob hinsche: Leipzig, 1911.

Vorlesungen uber schöne Literatur und Kunst, ed. Jakob Winor. stuttgart, 1884. (Deutgahe II tera turdenkmale des 18. und 19. Jahrhunderts, 17-19).

Esse1s 11ttera1res at historiques. Bonn, 1842.

Geschichte der deutschen Sprache und Poesle, ed. Josef Korner. Berlin, 1913* (Deutsche Il tera turdenkmale des 18. und 19. Jahrhunderts, 147).

A* W. Schlegel's Lectures on German Iltereture from Gottgched to Goothe GIven at the Un17ersity af Bonn and Laken Down by George Townbee, ed. H. G. FIe dlex. 0rford, 1944.

Briefe von und an A. W. Schlegel, ed. Jogef Korner. 2 V01s. Zurich, 1930.

Krisenfahre der Frihromantik. Briefe aus dem Schlegelkreis, ed. Jo sef Korner. 2 Vols. Brinn, 1936.

August Wilhelm und Friedrich Schlegel im Briefweahsel mit Sohilier und Goothe, ed. Josel kormer and Frngt

Nienelse. Le1pzig; 1926. 
II. Selected secondery works.

Besenbeok, Alfred. Funstanschauung und Kunstlohre August Wilhelm Sohlegelg. Berlin, 1930. TGermanistischo studien, 87).

Fmersleben, August. Die Antike in der romantisehen Theor1e: D1e Gebruder Sohlegel und die Ant1ke. Beriln, 1937 .

Haym, Budalf. Die romant1sche Schule, 3. Aufl., ed. Oskar Walzel. Berlin, 1914.

Huch, Ricarda. Die Romantik, 5. Aufl. 2 vola. Le1pzig, 1913.

Jesinghaus, Walter. August W1lhelm Schlegels Me1nungen uber Urspreahe. Dusseldorf, I913.

Korff, H. A. Geist der Goetheze1t. III. Te11: Fruhromant1k. 2. Nachdruok der 3. Aufl. Leipzig, 1959.

Körner, Josef. Romantiker und Klassiker: die Brider Schlegel in 1hren Bezlehungen zu Schlilex und Gothe. Berlin, 1924.

Iovejoy, A. 0. "The Meaning of 'Romant10' in Farly German Romantici sm," MIN, XXXI (1916) 385-96, XXXII (1917) 65-77. Reprinted in h1s Esgers in the H1story of Ideas (Baltimore, 1948) pp.183-206.

Pange, Pauline. Auguat W1lhelm Schlegel und Frau von Stä1. Hamburg, 1940 .

Phelan, Anna Augusta (Helmholz). The Indebtednesg of Samuel Tavior Doleridge to August W11halm Schlogel. Mad180n, 1907. (Bulletin of the Univerg1 ty of W1sconsin, no.163. Philology and Itterature Serles, III, 273-370).

Schirmer, Walter F. "August Wilhelm Sohlegel. Drel Vorträge gehalten an der Universität London, November 1938," in his Kleine Schriften (Thingen, 1950) pp. $153-200$.

Walzel, Oskar. Deutsohe Roment1k, 4. Aufl. Ieipzig, 1918.

Wellek, Ren6. A H1story of Modern Or1t1c1sm, 1750-1950. Vo1. 2: The Romant1c Ige. New Haven, 1955.

Zehnder, Hans. Die Anfënge von August Hilhelm Schlegels krit1scher ritigke1t. Zurich, 1930 